\title{
WATER BUDGET AND THE EFFECTS OF LAND-USE CHANGES ON GROUND-WATER RECHARGE, OAHU, HAWAII
}

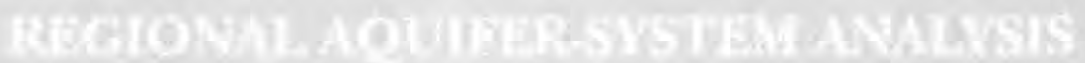

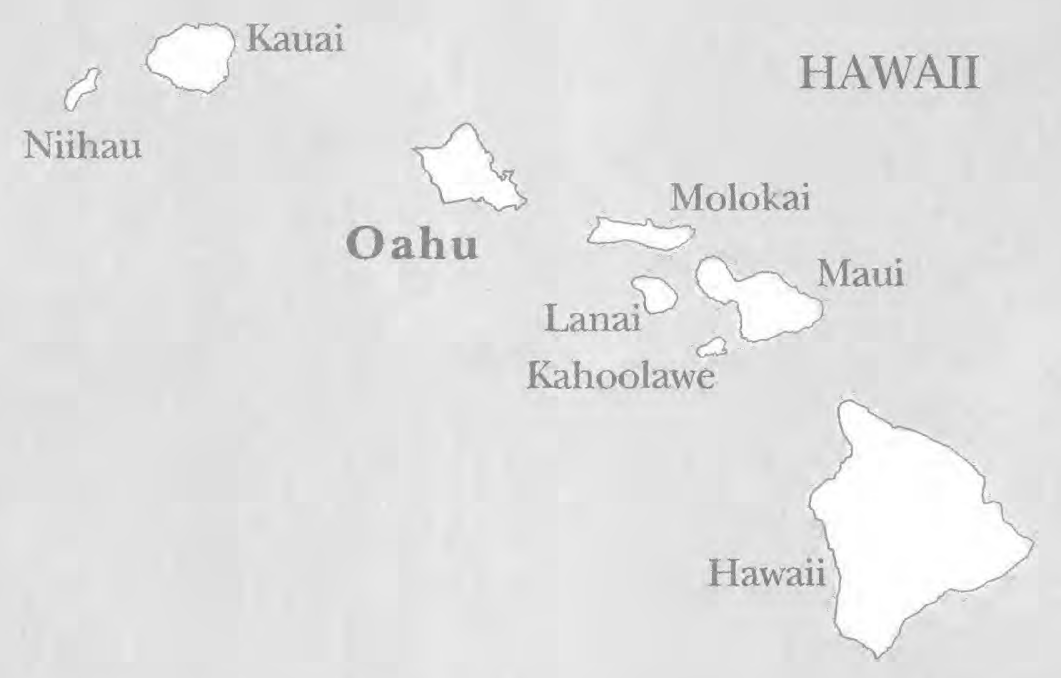

U.S. GEOLOGICAL SURVEY PROFESSIONAL PAPER 1412-C. 


\section{AVAILABILITY OF BOOKS AND MAPS OF THE U.S. GEOLOGICAL SURVEY}

Instructions on ordering publications of the U.S. Geological Survey, along with prices of the last offerings, are given in the current-year issues of the monthly catalog "New Publications of the U.S. Geological Survey." Prices of available U.S. Geological Survey publications released prior to the current year are listed in the most recent annual "Price and Availability List." Publications that may be listed in various U.S. Geological Survey catalogs (see back inside cover) but not listed in the most recent annual "Price and Availability List" may no longer be available.

Order U.S. Geological Survey publications by mail or over the counter from the offices given below.

\section{BY MAIL}

\section{Books}

Professional Papers, Bulletins, Water-Supply Papers, Techniques of Water-Resources Investigations, Circulars, publications of general interest (such as leaflets, pamphlets, booklets), single copies of Preliminary Determination of Epicenters, and some miscellaneous reports, including some of the foregoing series that have gone out of print at the Superintendent of Documents, are obtainable by mail from

\section{U.S. Geological Survey, Information Services Box 25286, Federal Center, Denver, CO 80225}

Subscriptions to Preliminary Determination of Epicenters) can be obtained ONLY from the

\section{Superintendent of Documents \\ Government Printing Office \\ Washington, D.C. 20402}

(Check or money order must be payable to Superintendent of Documents.)

Maps

For maps, address mail orders to

U.S. Geological Survey, Information Services Box 25286, Federal Center, Denver, CO 80225

\section{OVER THE COUNTER}

\section{Books and Maps}

Books and maps of the U.S. Geological Survey are available over the counter at the following U.S. Geological Survey Earth Science Information Centers (ESIC's), all of which are authorized agents of the Superintendent of Documents:

- ANCHORAGE, Alaska-Rm. 101, 4230 University Dr.

- LAKEWOOD, Colorado-Federal Center, Bldg. 810

- MENLO PARK, California-Bldg. 3, Rm. 3128, 345 Middlefield Rd.

- RESTON, Virginia-USGS National Center, Rm. 1C402, 12201 Sunrise Valley Dr.

- SALT LAKE CITY, Utah-Federal Bldg., Rm. 8105, 125 South State St.

-SPOKANE, Washington-U.S. Post Office Bldg., Rm. 135, West 904 Riverside Ave.

- WASHINGTON, D.C.-Main Interior Bldg., Rm. 2650, 18th and C Sts., NW.

\section{Maps Only}

Maps may be purchased over the counter at the following U.S. Geological Survey offices:

- ROLLA, Missouri-1400 Independence Rd.

- STENNIS SPACE CENTER, Mississippi-Bldg. 3101 


\section{Water Budget and the Effects of Land-Use Changes on Ground-Water Recharge, Oahu, Hawaii}

By PATRICIA J. SHADE and WILLIAM D. NICHOLS

REGIONAL AQUIFER-SYSTEM ANALYSIS-OAHU, HAWAII

U.S. GEOLOGICAL SURVEY PROFESSIONAL PAPER 1412-C 


\title{
U.S. DEPARTMENT OF THE INTERIOR \\ BRUCE BABBITT, Secretary
}

\author{
U.S. GEOLOGICAL SURVEY
}

Gordon P. Eaton, Director Any use of trade, product, or firm names in this publication is for
descriptive purposes only and does not imply endorsement by the

U.S. Government.

\section{Library of Congress Cataloging in Publication Data}

Shade, Patricia J.

Water budget and the effects of land-use changes on ground-water recharge, Oahu, Hawaii / by Patricia J. Shade and William D. Nichols.

p. cm. - (Regional aquifer-system analysis-Oahu, Hawaii) (U.S. Geological Survey Professional Paper ; 1412-C) Includes bibliographic references.

Supt. of Docs. no. : I 19.16:1412-C

1. Water balance (Hydrology)-Hawaii-Oahu. 2. Ground-water flow-Hawaii-Oahu

I. Nichols, William D. II. Title. III. Series. IV. Series: U.S. Geological Survey professional paper ; 1412-C.

GB1025.H3S53 1996

$551.49^{\prime} 09969^{\prime} 3-\mathrm{dc} 20$

For sale by the U.S. Geological Survey, Branch of Information Services, Box 25286, Federal Center, Denver, CO 80225 


\section{FOREWORD}

The Regional Aquifer-System Analysis (RASA) Program represents a systematic effort to study a number of the Nation's most important aquifer systems, which, in aggregate, underlie much of the country and which represent an important component of the Nation's total water supply. In general, the boundaries of these studies are identified by the hydrologic extent of each system and, accordingly, transcend the political subdivisions to which investigations have often arbitrarily been limited in the past. The broad objective for each study is to assemble geologic, hydrologic, and geochemical information; to analyze and develop an understanding of the system; and to develop predictive capabilities that will contribute to the effective management of the system. The use of computer simulation is an important element of the RASA studies to develop an understanding of the natural, undisturbed hydrologic system and the changes brought about in it by human activities and to provide a means of predicting the regional effects of future pumping or other stresses.

The final interpretive results of the RASA Program are presented in a series of U.S. Geological Survey Professional Papers that describe the geology, hydrology, and geochemistry of each regional aquifer system. Each study within the RASA Program is assigned a single Professional Paper number beginning with Professional Paper 1400.

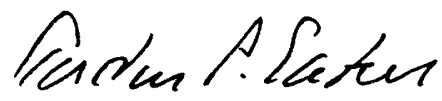

Gordon P. Eaton

Director 



\section{CONTENTS}

\begin{tabular}{|c|c|}
\hline & 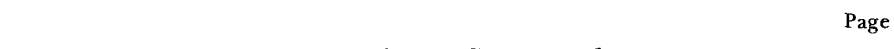 \\
\hline 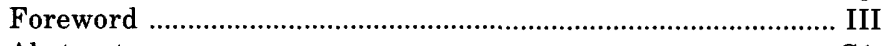 & Predevelopment Water Budget-Continued \\
\hline bstract & Waianae Area \\
\hline troduction & Island of Oahu \\
\hline Purpose and Scope & Distribution of Predevelopment Ground-Water \\
\hline rea & Recharge ................. \\
\hline 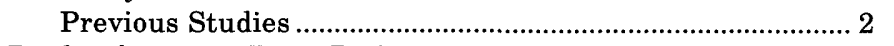 & Effects of L \\
\hline 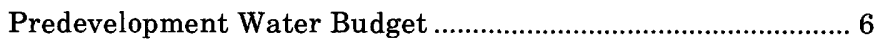 & 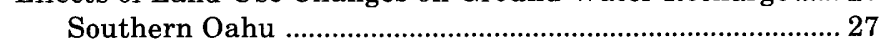 \\
\hline 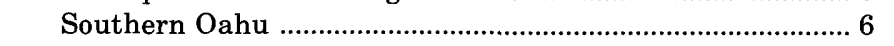 & 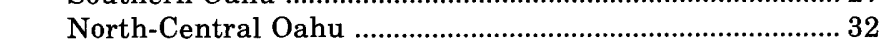 \\
\hline u & Distribution of Mid-1980's Grou \\
\hline 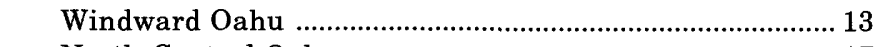 & ummary and Conclusions ............... \\
\hline North-Central Oahu & 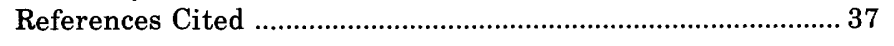 \\
\hline
\end{tabular}

\section{ILLUSTRATIONS}

FiguREs 1-4. Maps showing:

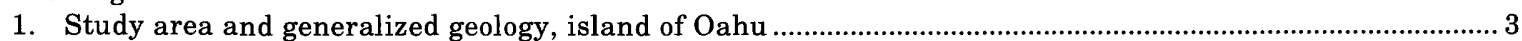

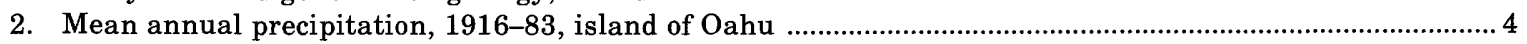

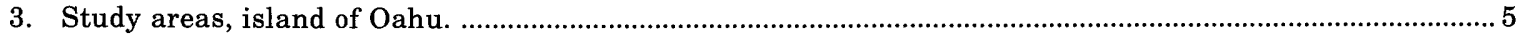

4. Mid-1980's land use and mean annual precipitation, southern Oahu ........................................................ 7

5. Graph showing relation between precipitation and estimated ground-water recharge for

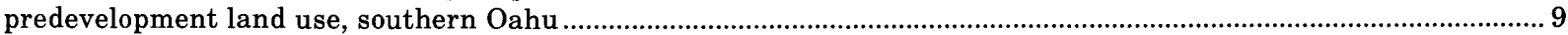

6. Graph showing relation between precipitation and estimated runoff for predevelopment land use, southern Oahu

7. Map showing mean annual precipitation and areas of relatively low and high soil permeability, southeastern Oahu

8. Graph showing relation between precipitation and estimated ground-water recharge based on relative soil permeability, southeastern Oahu

9. Graph showing relation between precipitation and estimated runoff, southeastern Oahu ........................................ 13

10-17. Maps showing:

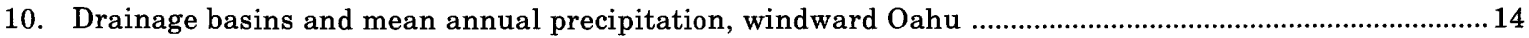

11. Drainage basins and mean annual pan evaporation, windward Oahu ......................................................15

12. Mid-1980's land use and mean annual precipitation, north-central Oahu ..................................................18

13. Mean annual precipitation and areas of phreatophytes and of relatively low and

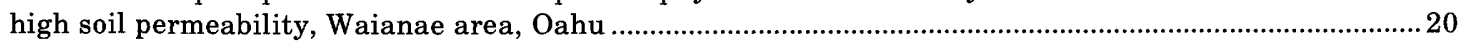

14. Distribution of ground-water recharge for predevelopment land use, island of Oahu ................................23

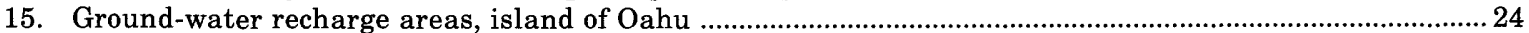

16. Distribution of predevelopment recharge to and discharge from the noncaprock areas, southern and north-central Oahu

17. Distribution of predevelopment recharge to and discharge from windward Oahu basins, Waianae area, and southeastern Oahu

18-22. Graphs showing.

18. Relation (general trend) between precipitation and estimated ground-water recharge for natural and urban land uses during the mid-1980's, southern Oahu

19. Relation (general trend) between precipitation and estimated ground-water recharge in areas of drip-irrigated sugarcane during the mid-1980's, southern Oahu

20. Relation (general trend) between precipitation and estimated ground-water recharge in areas of pineapple cultivation during the mid-1980's, southern Oahu ..................................................29

21. Estimated ground-water recharge for predevelopment and mid-1980's land use, southern Oahu ..............30

22. Relation (general trends) between precipitation and estimated runoff for natural and urban land uses during the mid-1980's, southern Oahu

23. Map showing distribution of ground-water recharge for mid-1980's land use, island of Oahu ..................................34

24. Map showing distribution of recharge to and discharge from the noncaprock areas for mid-1980's land use, southern and north-central Oahu, 


\section{TABLES}

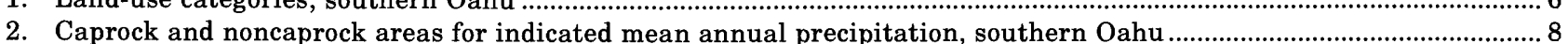

3. Regression equation coefficients for ground-water recharge for predevelopment land use, southern Oahu ..................... 8

4. Regression equation coefficients for runoff for predevelopment land use, southern Oahu ............................................10

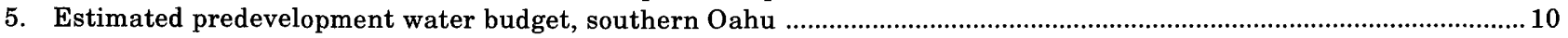

6. Predevelopment water budget for the area defined by a geographic information system, southern Oahu ..................... 10

7. Regression equation coefficients for ground-water recharge, southeastern Oahu .........................................................12

8. Areas for given relative soil permeability and mean annual precipitation, southeastern Oahu ....................................12

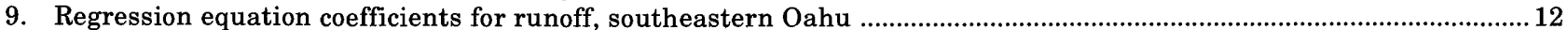

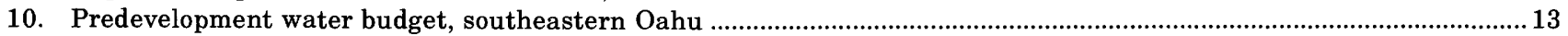

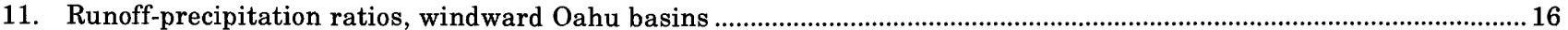

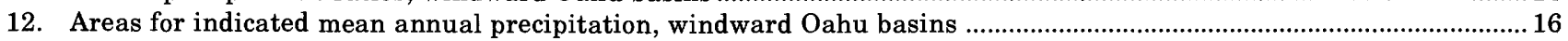

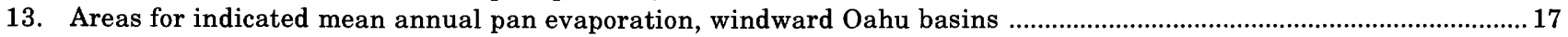

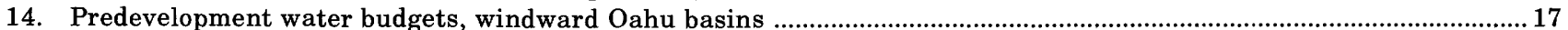

15. Estimated water budgets for selected windward Oahu basins .....................................................................................17

16. Caprock and noncaprock areas for indicated mean annual precipitation, north-central Oahu .....................................19

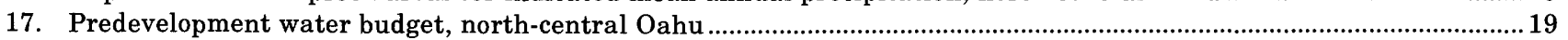

18. Areas of phreatophyte and non-phreatophyte land cover and relative soil permeability

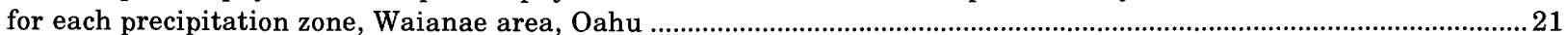

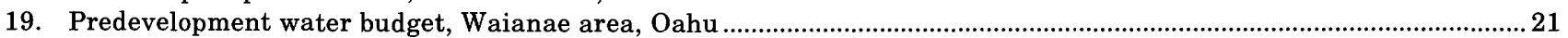

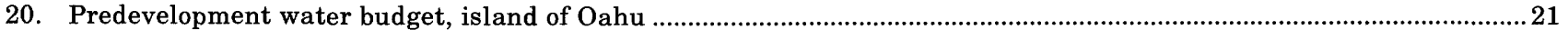

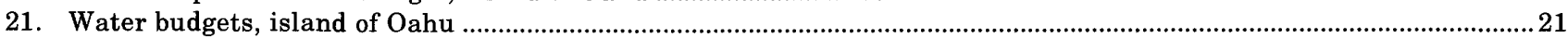

22. Distribution of ground-water recharge for predevelopment land use, island of Oahu ..................................................22

23. Regression equation coefficients for ground-water recharge for mid-1980's nonagricultural land use, southern Oahu ...

24. Areas of agricultural and nonagricultural land use during the mid-1980's, southern Oahu .........................................28

25. Predevelopment and mid-1980's recharge to indicated areas of mid-1980's land use, southern Oahu .............................30

26. Regression equation coefficients for runoff for mid-1980's land use, southern Oahu ......................................................31

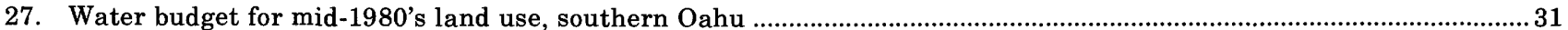

28. Areas of agricultural and nonagricultural land use during the mid-1980's, north-central Oahu ...................................32 32

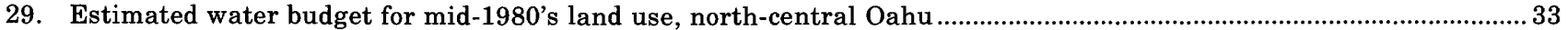

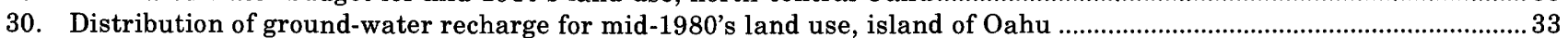

31. Estimated predevelopment and mid-1980's ground-water recharge to noncaprock areas

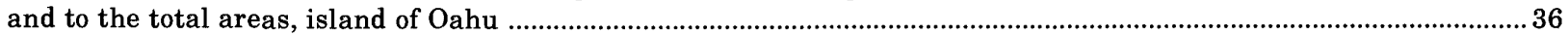

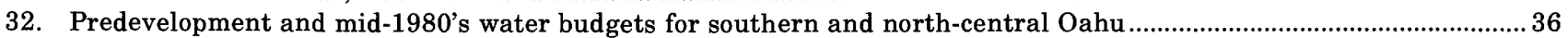

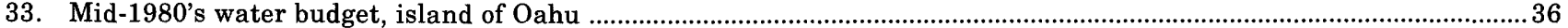

\section{CONVERSION FACTORS}

\begin{tabular}{rll}
\hline Multiply & By & To obtain \\
\hline acre & 0.4047 & square hectometer $\left(\mathrm{hm}^{2}\right)$ \\
foot (ft) & 0.3048 & meter $(\mathrm{m})$ \\
foot per year (ft/yr) & 0.3048 & meter per year $(\mathrm{m} / \mathrm{yr})$ \\
gallon (gal) & 0.003785 & cubic meter $\left(\mathrm{m}^{3}\right)$ \\
inch (in.) & 25.4 & millimeter $(\mathrm{mm})$ \\
inch per year (in/yr) & 25.4 & millimeter per year $(\mathrm{mm} / \mathrm{yr})$ \\
mile (mi) & 1.609 & kilometer $(\mathrm{km})$ \\
square mile $\left(\mathrm{mi}^{2}\right)$ & 2.590 & square kilometer $\left(\mathrm{km}^{2}\right)$ \\
cubic meter per second $\left(\mathrm{m}^{3} / \mathrm{s}\right)$ \\
\hline
\end{tabular}




\title{
WATER BUDGET AND THE EFFECTS OF LAND-USE CHANGES ON GROUND-WATER RECHARGE, OAHU, HAWAII
}

\author{
By P.J. Shade and W.D. Nichols
}

\begin{abstract}
Detailed water budgets calculated for southern and southeastern Oahu are used with a geographic information system to develop simplified methods for estimating areal water budgets for predevelopment and mid-1980's land use. The methods were applied to estimate water budgets for the Waianae area of western Oahu, and for north-central, southern, and southeastern Oahu. A water budget was calculated for windward Oahu by developing a separate geographic information system model of the area. The water budgets for these areas were combined into a single water budget for the entire island. The geographic information system model was used to calculate mid1980 's ground-water recharge to small areas of specific interest and to determine the distribution of recharge by geologic formation.

The most significant changes in the water budget and ground-water recharge have occurred in north-central and southern Oahu as a result of large-scale agricultural development and urbanization by the mid-1980's. Runoff increased by 23 million gallons per day in southern Oahu where extensive urban areas had been developed. Evapotranspiration increased by 8 million gallons per day in southern Oahu and 28 million gallons per day in north-central Oahu as a result of the 146 million gallons per day of agricultural irrigation. Ground-water recharge increased in both areas by about 56 million gallons per day in southern Oahu and by about 32 million gallons per day in north-central Oahu. Predevelopment ground-water recharge to Oahu was an estimated 792 million gallons per day. Changes in land-use practices in the mid-1980's resulted in an estimated islandwide recharge of 880 million gallons per day.
\end{abstract}

\section{INTRODUCTION}

The water supply for the population of the island of Oahu, Hawaii, is obtained primarily from ground-water sources that are recharged by infiltration of precipitation and applied irrigation water. The importance and limited nature of these recharge sources to the groundwater system led to the inclusion of the island of Oahu, together with 27 other regions of the United States, in the U.S. Geological Survey's Regional Aquifer-System Analysis (RASA) Program.

An important factor in the study of aquifer systems is the quantity of water that recharges the ground-water system. Recharge to the ground-water system can be estimated from water-budget calculations by subtracting runoff and evapotranspiration from precipitation and applied irrigation water. The quantification and distribution of the water-budget elements are important in water-resource appraisal studies and in the numerical analysis of the ground-water flow systems.
Water budgets were calculated for each of the five study areas defined for Oahu as part of the RASA project (Eyre and others, 1986). Two of these study area boundaries are topographic divides that broadly coincide with less well-defined ground-water flow boundaries. The Waialua-Wahiawa district boundary is used simply as a convenient north-south division across the Schofield Plateau. The Kaau Rift Zone is a geohydrologic divide. Previous water-budget studies commonly encompassed smaller subsets of these areas. Because boundaries were not standardized, the previous study areas are not comparable to the RASA study areas, and the results of previous studies are difficult to compare with one another and with the RASA study results.

\section{PURPOSE AND SCOPE}

The purpose of this report is to describe the calculation of a predevelopment and a mid-1980's water budget for five major study areas of the island of Oahu, and the spatial distribution and temporal change in groundwater recharge caused by changes in land use. Which of several methods that were used to calculate the elements of the water budget and to estimate ground-water recharge depended on the area being analyzed and on the availability of previous data. The calculation of water budgets and display of the resulting recharge distributions were aided by the use of a geographic information system (GIS) that combines spatial and numerical data for a particular area in a digital form. As a result, each location on a map has various attribute data-precipitation, ground-water recharge, and geologic unit-characterizing it. The water budgets for the individual areas are combined into a water budget for the entire island.

\section{STUDY AREA}

The study area includes the entire island of Oahu (fig. 1), which encompasses about $596 \mathrm{mi}^{2}$ of land area. The Koolau Range extends from the southeastern tip of the island northwestward to the northern coast. These 
mountains reach altitudes of $2,000 \mathrm{ft}^{1}$ along most of the crest, and several peaks are more than $2,400 \mathrm{ft}$. The Waianae Range is located on the western side of the island and reaches altitudes of $2,000 \mathrm{ft}$ along much of the crest of the range; several peaks reach altitudes of 3,500 and $4,000 \mathrm{ft}$.

Oahu is underlain by two major aquifers. The Waianae aquifer, which is within the Waianae Volcanics of Pliocene age (fig. 1), underlies the western one-quarter of the island and extends eastward an unknown distance in the subsurface; and the Koolau aquifer, which is within the Koolau Basalt of Pliocene and Pleistocene age, underlies the eastern three-quarters of the island. The Koolau aquifer is the main source of water for southern Oahu and, hence, for the city of Honolulu. It also is the main source of water for irrigation of agricultural crops in southern Oahu, which included about 15,750 acres of irrigated sugarcane and about 11,670 acres of pineapple in the mid-1980's.

Bordering the island along the southern and northern coastal areas are coastal-plain deposits locally known as caprock (fig. 1). These deposits include marine and terrestrial sediments, limestone, and reef deposits. In southern and north-central Oahu, the caprock confines the ground water in the underlying basalt aquifer. This impedes discharge of ground water to the sea and, especially in southern Oahu, raises inland ground-water levels to higher altitudes than would otherwise be the case. The impoundment of water by the caprock increases the volume of freshwater stored in the aquifers. Recharge from precipitation and irrigation-return flow in the caprock areas, however, does not reach the underlying basalt aquifers and does not contribute usable recharge to the ground-water system. In the following analysis of water budgets and ground-water recharge for southern and north-central Oahu, recharge to the caprock and noncaprock areas is considered separately.

An extreme range in annual precipitation extends over Oahu (fig. 2). Mean annual precipitation ranges from less than $25 \mathrm{in} / \mathrm{yr}$ in the western and southern parts of the island to more than $275 \mathrm{in} / \mathrm{yr}$ over the highest part of the Koolau Range. Figure 2 is based on records from a network of 13 base stations that have data from 1916 to 1983 (Giambelluca and others, 1986).

Water budgets were estimated for the five major study areas on Oahu (Eyre and others, 1986) (fig. 3A):

1. Southern Oahu $\left(260.5 \mathrm{mi}^{2}\right)$, which includes the main population centers of Honolulu and the Pearl Harbor area and extensive agricultural areas;

2. Southeastern Oahu $\left(28.4 \mathrm{mi}^{2}\right)$, which is largely a residential area with large tracts of conservation land along the ridges and steep slopes of the Koolau Range and along much of the coast;
3. Windward Oahu (124.5 mi ${ }^{2}$, which includes military, agricultural, conservation, and low-density urban land use;

4. North-central Oahu $\left(121.4 \mathrm{mi}^{2}\right)$, which is predominantly an agricultural area with smaller areas of military, recreational, and low-density urban land use; and the

5. Waianae area $\left(60.9 \mathrm{mi}^{2}\right)$, which includes a large tract of military reservation land, agricultural, conservation, and a small area of low-density urban land use.

Geohydrologic barriers internally divide the study areas into smaller ground-water areas (fig. $3 B$ ) that have been referred to by Stearns and Vaksvik (1935), Visher and Mink (1964), Takasaki and Mink (1985), and by the authors of ground-water studies cited in the next section of this report.

\section{PREVIOUS STUDIES}

A number of previous studies have addressed the water budget or estimated ground-water recharge in the study areas of the island (fig. $3 A$ ), but only one previous investigation has attempted to develop a water budget for the entire island (Takasaki, 1978). Southern Oahu has been the most intensely studied area because it contains the principal source of water supply for the most heavily populated part of the island, and it is the most intensely irrigated agricultural area of the island. Most of the studies in southern Oahu have concentrated on making estimates of ground-water recharge. Wentworth (1951) presented one of the earliest estimates of a water budget for various parts of the southern Oahu area. Visher and Mink (1964) studied the ground-water resources of southern Oahu, but did not directly address the issues of a water budget or ground-water recharge. Dale (1967) discussed the effects of land use, specifically irrigated agriculture, on recharge to the ground-water system in part of the southern Oahu area. Mink (1980) estimated a predevelopment water budget for much of the southern Oahu area, and also estimated irrigation-return flow for land-use conditions during an undefined period before 1972. The most detailed water-budget study for southern Oahu was made by Giambelluca $(1983,1986)$. His studies constitute the basis for the southern Oahu water-budget estimate presented in this report.

The rest of Oahu has been studied less intensely. Eyre and others (1986) developed a water budget for southeastern Oahu for use in a numerical analysis of groundwater flow in that area. Their budget provides the basis for the water budget for southeastern Oahu in the present study. Takasaki and others (1969) presented wa-

$\overline{{ }^{1} \text { Above sea level. }}$ 


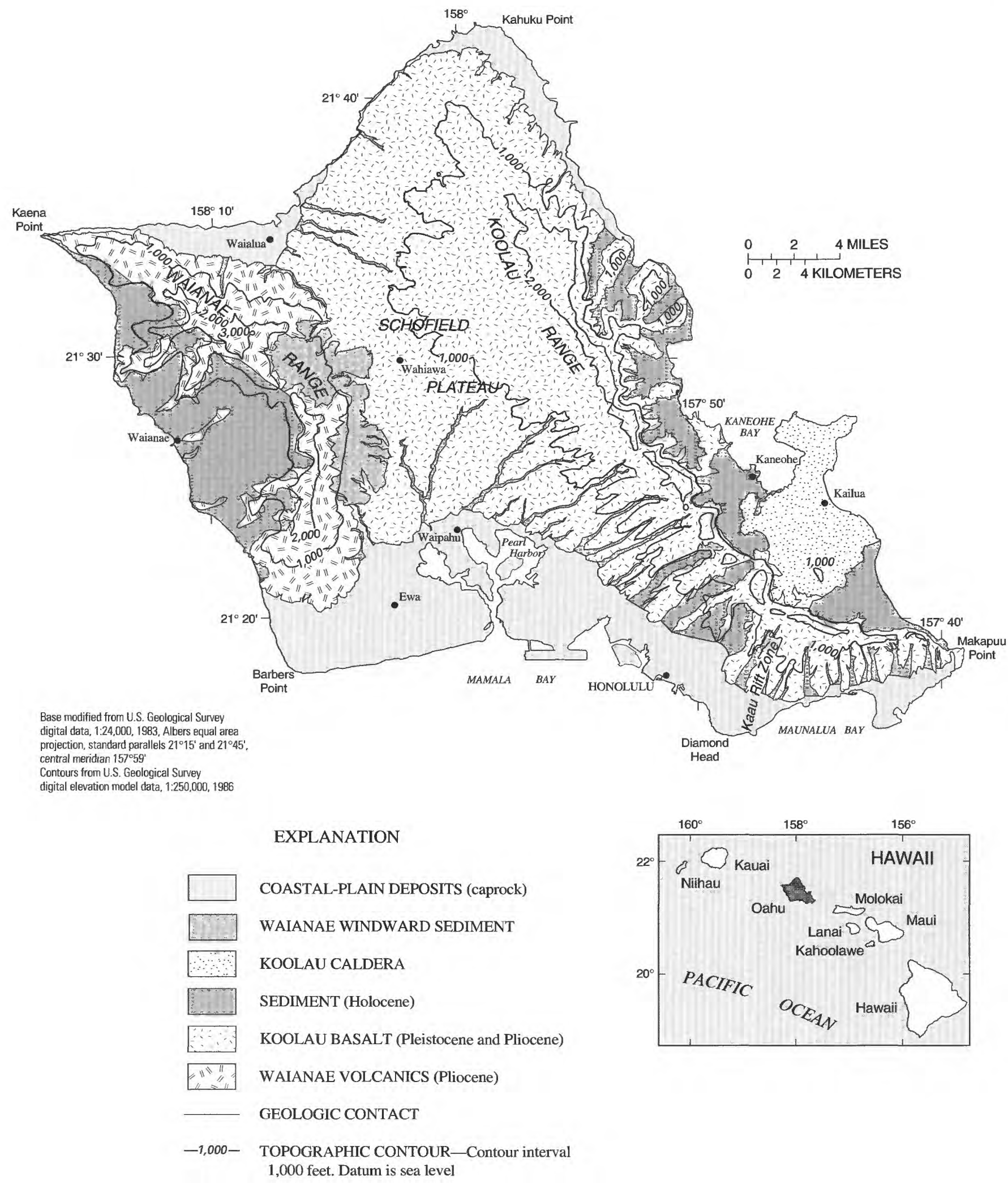

FIGURE 1.-Study area and generalized geology, island of Oahu (modified from Stearns, 1939). 
ter budgets for several of the windward Oahu drainage basins. Takasaki and Valenciano (1969) estimated a water budget for the Kahuku area in northeastern Oahu that corresponds approximately to the Kahuku basin of windward Oahu in the present study. Rosenau and others (1971) presented a water budget for part of northcentral Oahu, but their study area did not have the same boundaries as the north-central Oahu area of the present study. Dale (1978) and Dale and Takasaki (1976) estimated ground-water recharge to part of the northcentral Oahu area. Takasaki (1971) discussed components of a water budget for the Waianae area, but did not estimate ground-water recharge.

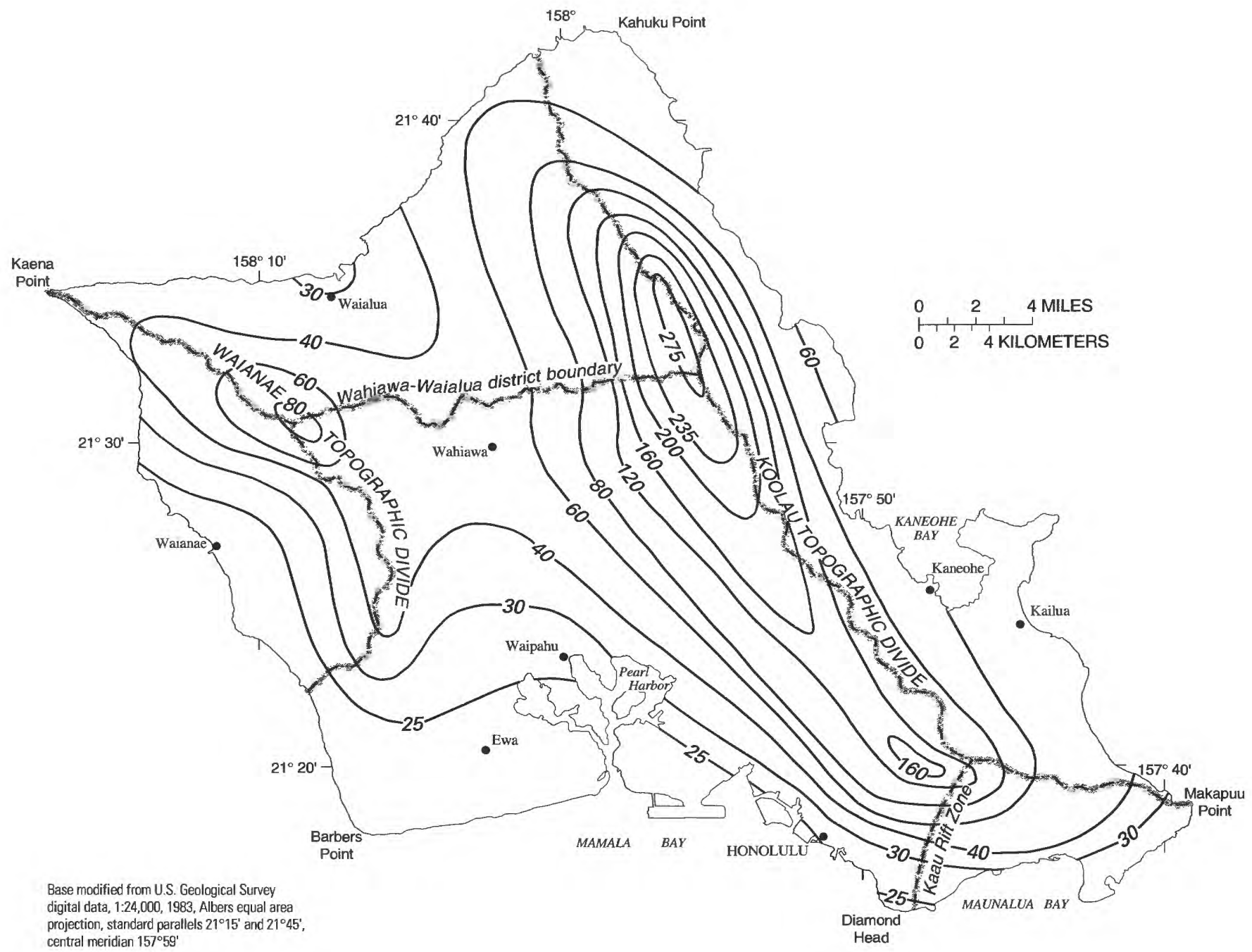

EXPLANATION

— 40- LINE OF EQUAL MEAN ANNUAL PRECIPITATION-

Interval, in inches, is variable

MAJOR STUDY-AREA BOUNDARY

FIGURE 2.-Mean annual precipitation, 1916-83, island of Oahu (modified from Giambelluca and others, 1986). 
A.

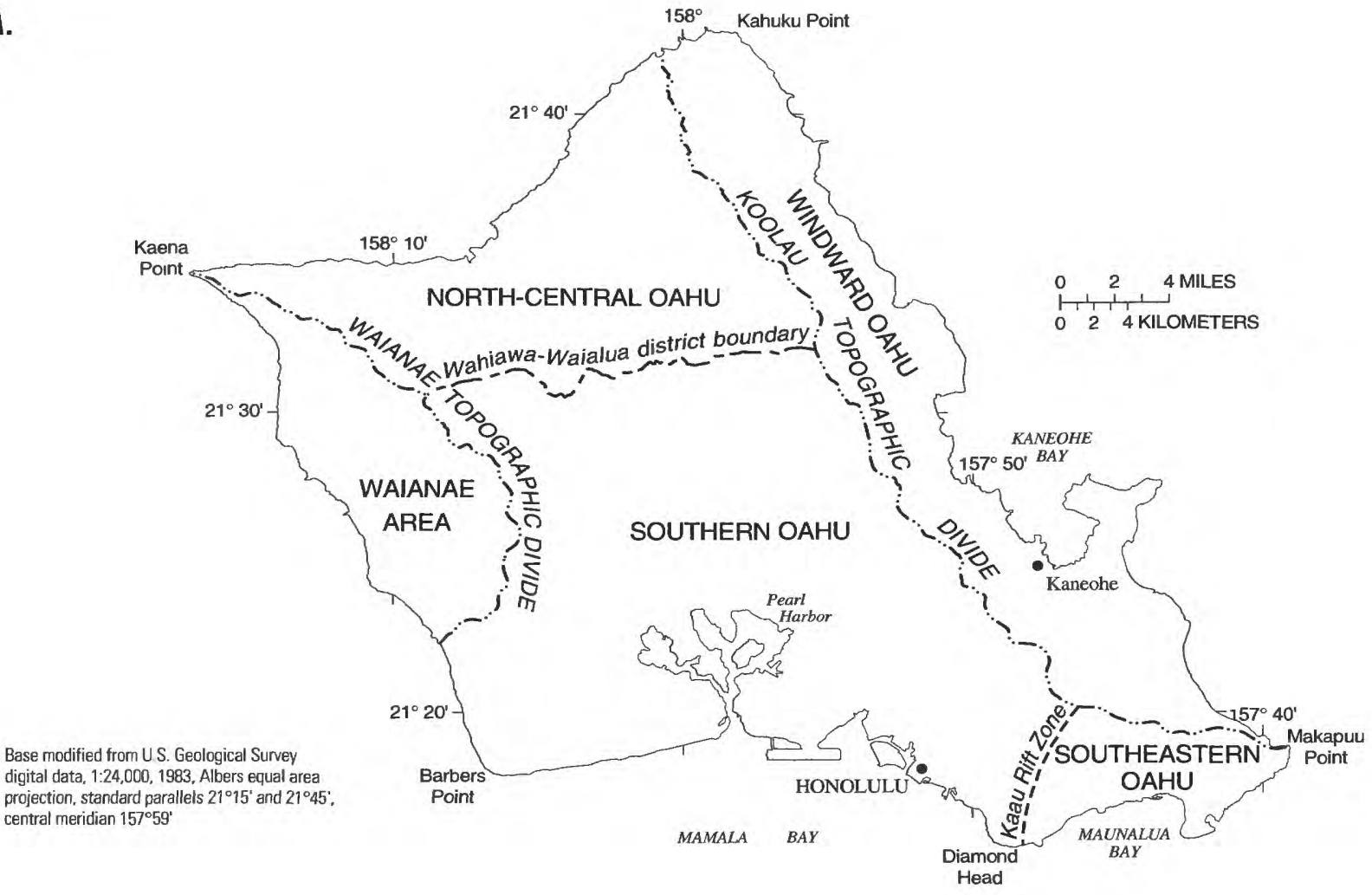

B.

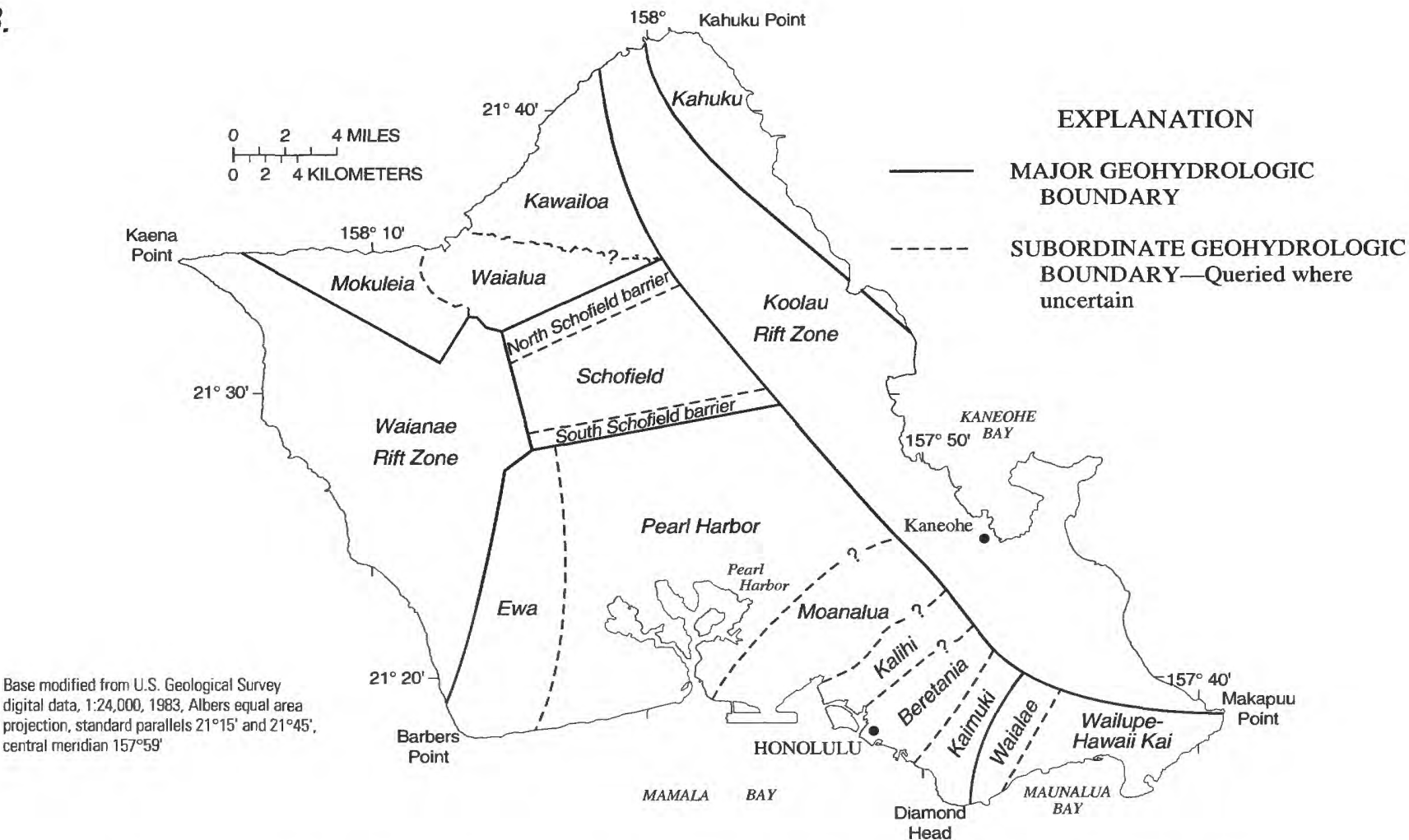

FIGURE 3.-Study areas, island of Oahu. A, Major study areas; topographic divides. B, Relation among topographic divides, geohydrologic barriers, and ground-water areas. 


\section{PREDEVELOPMENT WATER BUDGET}

A water budget for natural conditions is presented for each of the five study areas of the island of Oahu (fig. $3 A$ ). Each budget was developed by a somewhat different method, but each is designed to simplify earlier or more complicated methods to provide an easily applied and consistent approach for subsequent investigators. The methods utilize the capabilities of the GIS model. All the component data, including areas and mean annual precipitation, are included in this report. These data, together with equations presented in this report, can be used to calculate various elements of the water budget for any of the five study areas by using standard mathematical methods. Because of the gridlike nature of the GIS data bases used in the computational approach for this study, other methods that apply single values of various elements of the budget to large areas (that is, an entire study area) may yield somewhat different results.

\section{SOUTHERN OAHU}

A detailed monthly water budget calculated by Giambelluca (1983) for most of the southern Oahu area provided the basis for the method developed in the present study to estimate the water budget for the entire southern Oahu area before development. Giambelluca (1983) calculated each element of the water budget (precipitation, evapotranspiration, runoff, and ground-water recharge) for the different land-use categories (table 1) in the southern Oahu area. Giambelluca (Water Resources Research Center, University of Hawaii, written commun., 1985; 1986) prepared a similarly detailed water budget based on his 1983 methodology for about the same area of southern Oahu that is encompassed by the present study as part of the Hawaii RASA (fig. 4). However, neither the area encompassed by the 1983 study nor the area used in the 1985

\begin{aligned} & \multicolumn{2}{c}{ TABLE 1 - L Land-use categories, southern Oahu } \\ & \hline Category \multicolumn{1}{c}{ Land use } \\ & \hline 1 Furrow-irrigated sugarcane \\ & 2 Pineapple \\ & 3 Urban-low density \\ & 4 Urban-medium density \\ & 5 Urban-high density \\ & 6 Mixed (medium density urban, vacant) \\ & 7 Mixed (high and medium density urban) \\ & 8 Mixed (high density urban, vacant) \\ & 9 Parks, golf courses \\ & 10 Natural, includes vacant, forest, pasture \\ & 11 Drip-irrigated sugarcane \\ & \hline\end{aligned}

water budget model is totally coincident with the study area that is defined in the RASA project and used for the GIS analysis.

The 1983 study area did not extend as far north as the northern boundary of the southern Oahu area used in the present study, and the 1985 study area was not coincident with the crest of the Koolau Range. The difference between the area used in the 1985 study and this study is small, about $3 \mathrm{mi}^{2}$. However, because the excluded area is in the high precipitation zones, and, therefore high recharge zones, of the Koolau Range, the results of the regression model that uses the GIS-defined boundaries do not agree well with the results of Giambelluca (1986; Water Resources Research Center, University of Hawaii, written commun., 1985). To demonstrate the validity of the regression model, recharge must be estimated for the same area that Giambelluca used. Accordingly, to compare the two methods, the GIS area was reduced slightly to simulate Giambelluca's area for model calibration. The reduced area is referred to in the tables and the text as the "adjusted area." The total GIS-defined area is used for estimating the components of the islandwide water budget. The adjusted and total areas are given in table 2. Additionally, the areas are differentiated between caprock and noncaprock (fig. 1).

Giambelluca's (1983) approach was simplified by developing precipitation-recharge and precipitation-runoff relations for natural, predevelopment land use and for agricultural and urban land use presented later in this report using Giambelluca's data (Water Resources Research Center, University of Hawaii, written commun., 1985). A plot of estimated annual recharge in relation to mean annual precipitation is shown in figure 5. A single regression line does not adequately describe the relation, however, because it underestimates significant recharge in the high precipitation zones, as well as in those areas where annual precipitation ranges from 20 to about 35 in. Four regression equations were developed that more effectively describe the precipitation-recharge relation (fig. 5). The regression equation is of the general form

$$
\text { Recharge }=a(P p t)+b \text {, }
$$

where Recharge is the mean annual ground-water recharge rate, in inches; $a$ is the slope of the regression line; $P p t$ is the mean annual precipitation, in inches; and $b$ is the regression line intercept at the $y$ axis. The equation coefficients are given in table 3 . Predevelopment recharge to southern Oahu was calculated by selecting the areas in the GIS model in each precipitation range and then by applying the proper equation (tables 2,3 ). The resulting ground-water recharge was converted to million gallons per day. 


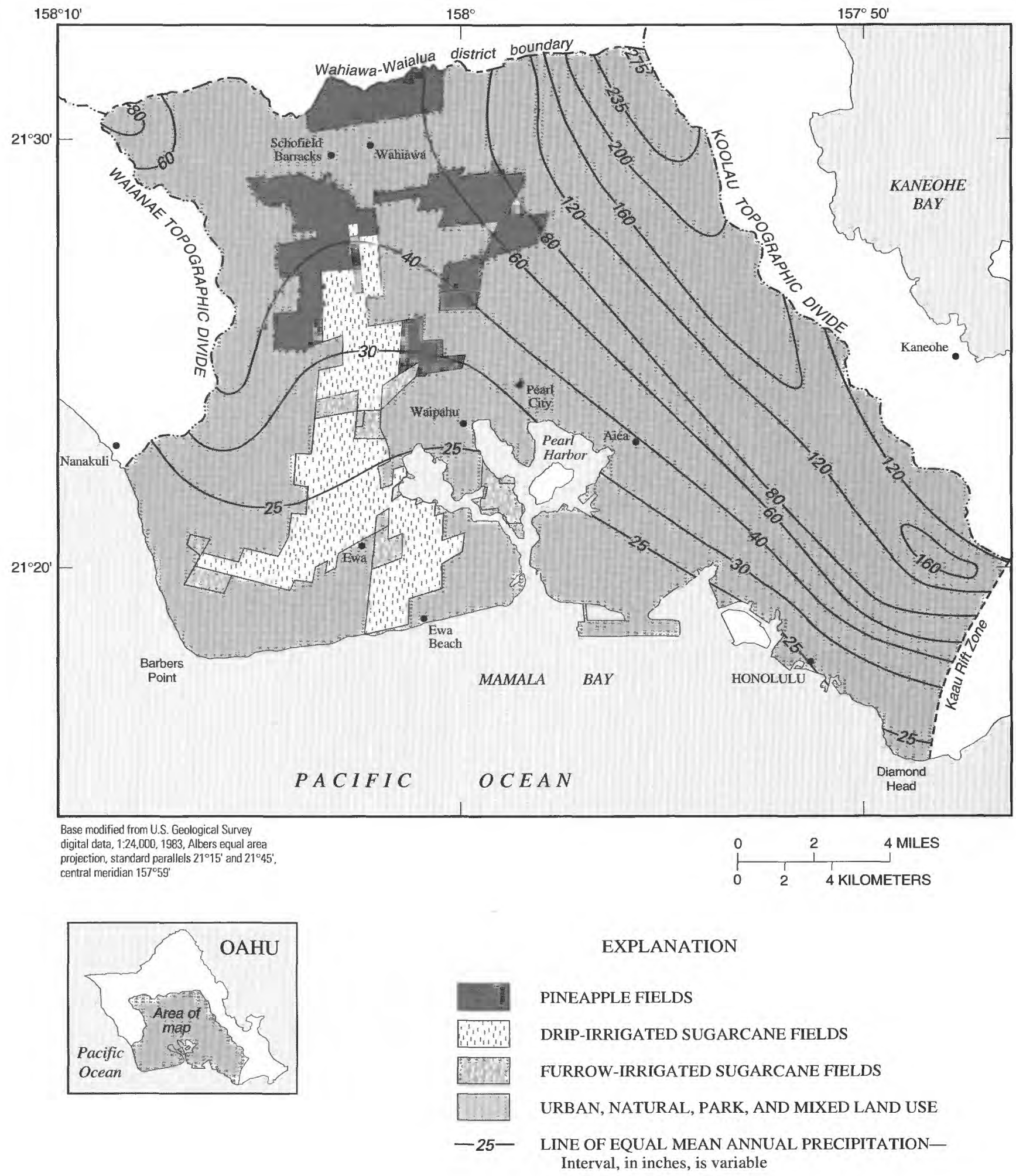

FIGURE 4.-Mid-1980's land use and mean annual precipitation, southern Oahu. 


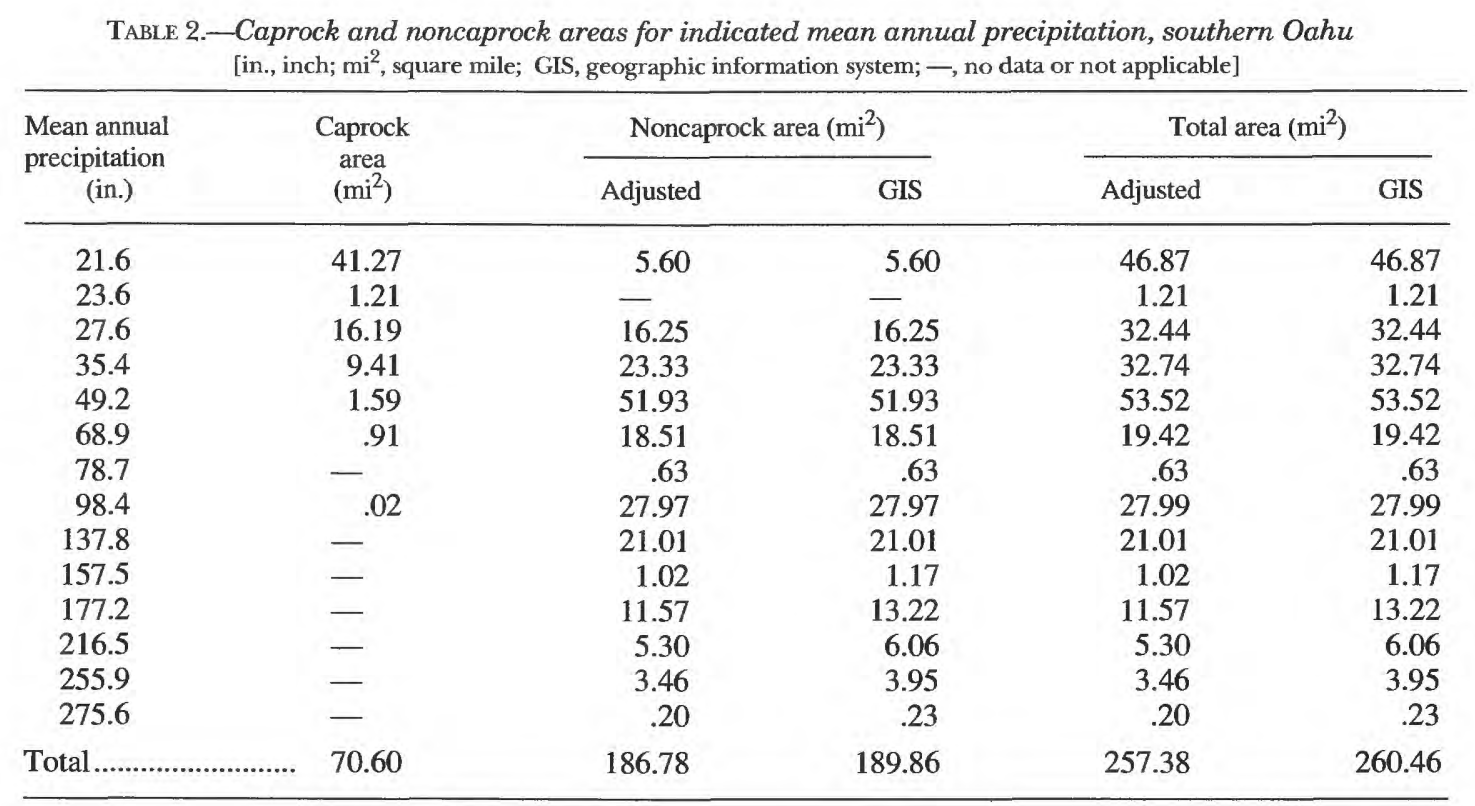

A similar analysis was made to determine the relation between precipitation and estimated runoff for natural, predevelopment land use calculated by T.W. Giambelluca (Water Resources Research Center, University of Hawaii, written commun., 1985). The data are shown in figure 6 , and as with recharge, several regression equations were needed to describe the data adequately. The general form of the equation is

$$
\text { Runoff }=a(P p t)^{b},
$$

where Runoff is the mean annual runoff, in inches; $P p t$ is the mean annual precipitation, in inches; and $a$ and $b$ are the regression coefficients. The regression coefficients to calculate runoff for ranges of mean annual precipitation are given in table 4 . Runoff for each precipitation zone was calculated by applying equation 2 in the same manner as equation 1. Evapotranspiration for the southern Oahu area was calculated as the residual of precipitation minus estimated recharge and runoff.

The predevelopment water budget for the southern Oahu study area determined by using the simple regression equations is compared with the water budget determined by using the more detailed method of T.W. Giambelluca (Water Resources Research Center, University of Hawaii, written commun., 1985) in table 5. The difference of $4 \mathrm{Mgal} / \mathrm{d}$ in recharge estimated by the two methods represents less than 1.5 percent of the estimated recharge. Giambelluca (1986) estimated recharge to the noncaprock part of southern Oahu at about $313 \mathrm{Mgal} / \mathrm{d}$; the regression model used in this study estimated about $310 \mathrm{Mgal} / \mathrm{d}$ to the adjusted noncaprock area of southern Oahu. Recharge to the noncaprock area of southern Oahu is significant because the area is underlain by basalt aquifers from which the area's ground-water supply is obtained. The 3-Mgal/d difference between the two estimates of recharge to the noncaprock area represents a difference of less than 1.0 percent. The close agreement among the elements of the budget calculated by each method (table 5) suggests that the regression model is an appropriate simplified method for estimating water budgets in southern Oahu. The water budget for the GIS-defined area of southern Oahu is given for caprock and noncaprock areas in table 6.

\begin{tabular}{|c|c|c|c|}
\hline $\begin{array}{c}\text { Mean annual } \\
\text { precipitation } \\
\text { range (in.) }\end{array}$ & $a$ & $b$ & $r^{2}$ \\
\hline $20-43$ & 0.06 & 3.4 & 0.09 \\
\hline $43-95$ & .78 & -28.0 & .93 \\
\hline $95-152$ & .6 & -15.0 & .24 \\
\hline$>152$ & .89 & -56.0 & .91 \\
\hline
\end{tabular}



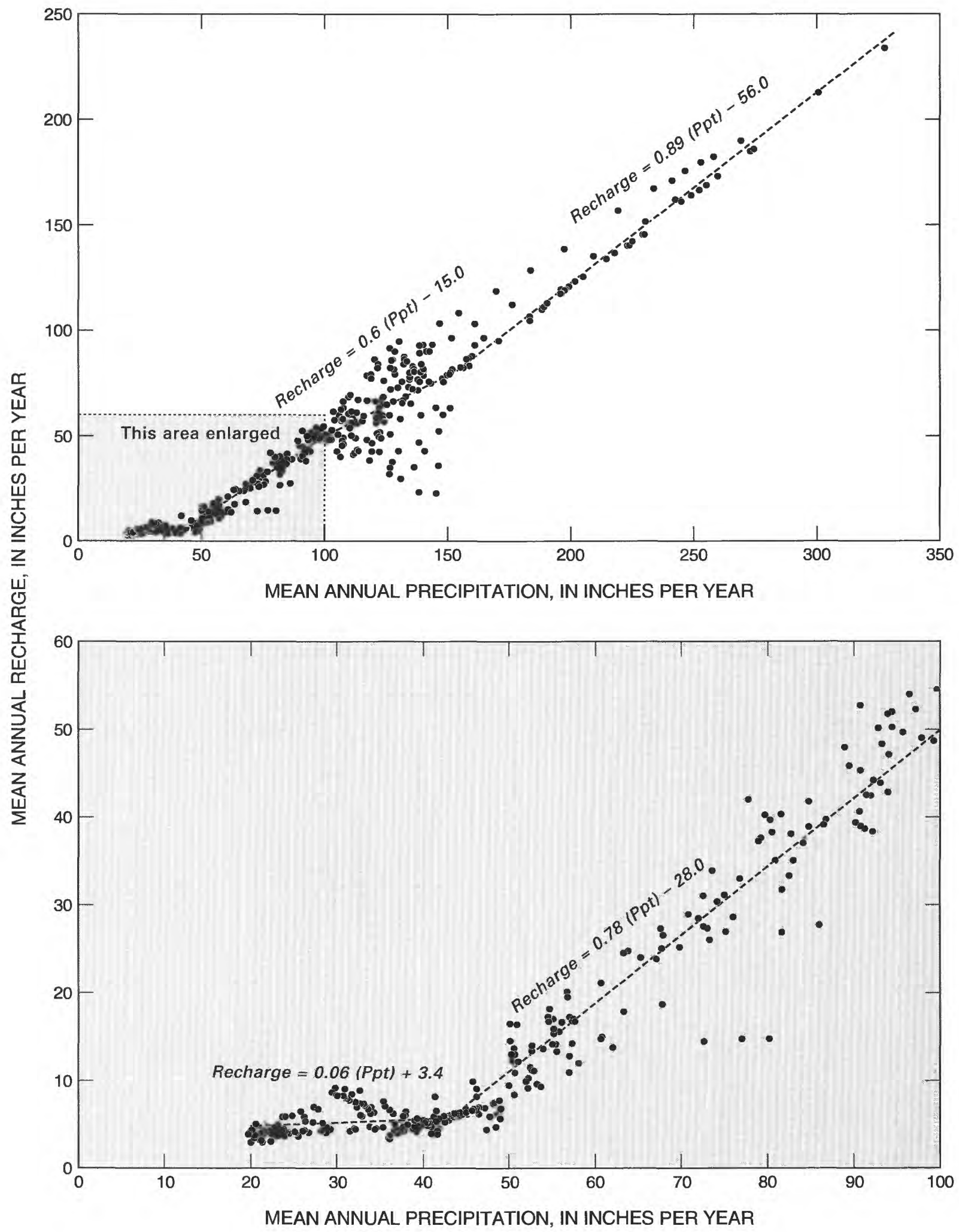

FIGURE 5.-Relation between precipitation and estimated ground-water recharge for predevelopment land use, southern Oahu. $P p t$, mean annual precipitation. 


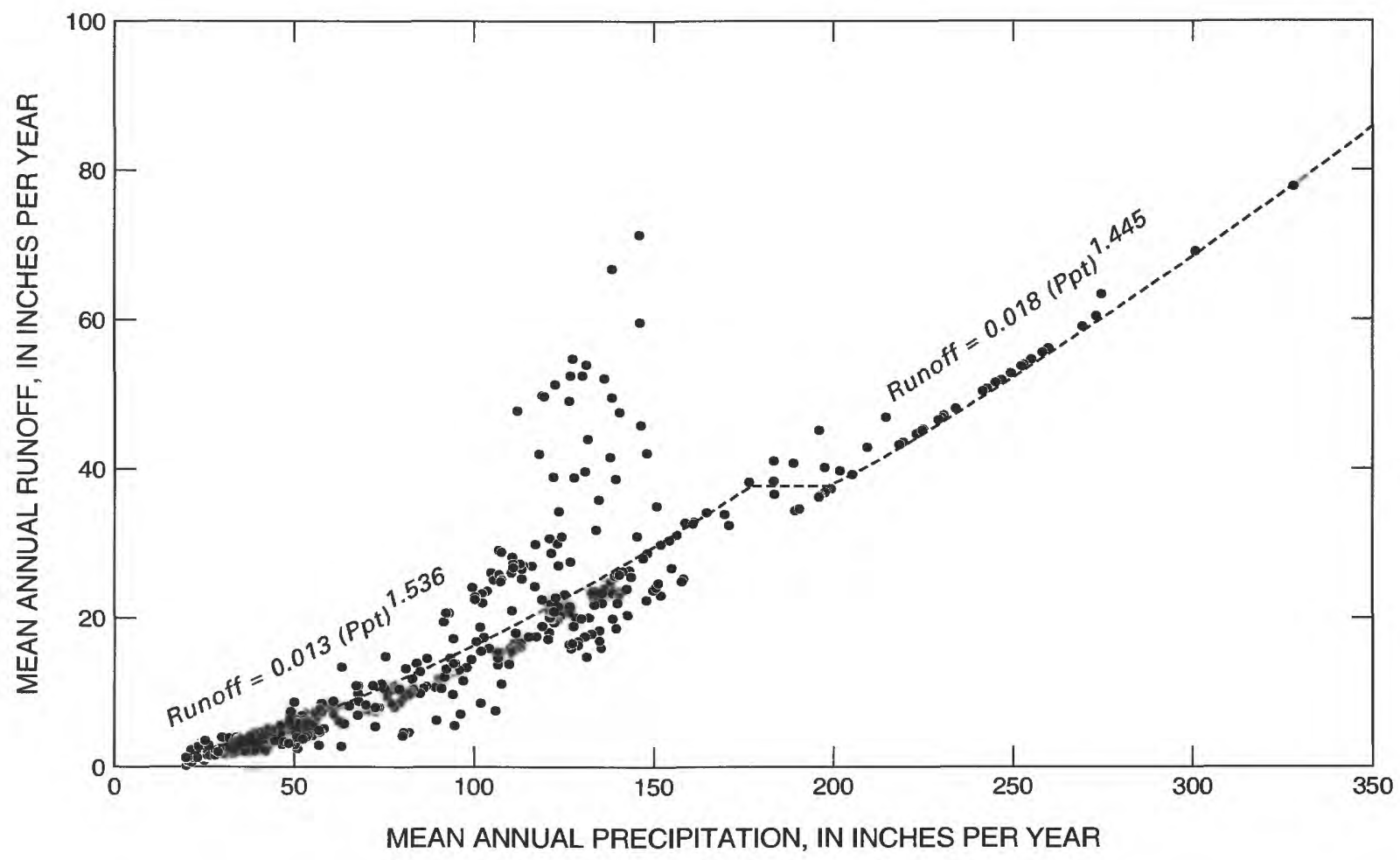

FIGURE 6.-Relation between precipitation and estimated runoff for predevelopment land use, southern Oahu. $P p t$, mean annual precipitation.

TABLE 4.-Regression equation coefficients for runoff for predevelopment land use, southern Oahu

[in., inch; $a$ and $b$, regression coefficients; $r^{2}$, coefficient of determination; $>$, actual value is greater than value shown; -, not applicable]

\begin{tabular}{|c|c|c|c|}
\hline $\begin{array}{c}\text { Mean annual } \\
\text { precipitation } \\
\text { range (in.) }\end{array}$ & $a$ & $b$ & $r^{2}$ \\
\hline 20-175 & 0.013 & 1.536 & 0.92 \\
\hline${ }^{1} 175-200$ & - & - & - \\
\hline$>200$ & .018 & 1.445 & .91 \\
\hline
\end{tabular}

${ }^{1}$ Constant 37.5 in. to connect power function curves.

TABLE 5.-Estimated predevelopment water budget, southern Oahu

[In million gallons per day]

\begin{tabular}{|c|c|c|}
\hline $\begin{array}{l}\text { Water-budget } \\
\text { category }\end{array}$ & Giambelluca $^{t}$ & $\begin{array}{c}\text { Adjusted } \\
\text { area }^{2}\end{array}$ \\
\hline 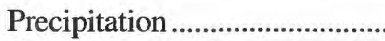 & 802 & 808 \\
\hline Evapotranspiration & .... 362 & 363 \\
\hline 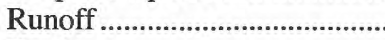 & ... 117 & 118 \\
\hline Recharge & 323 & 327 \\
\hline
\end{tabular}

${ }^{1}$ T.W. Giambelluca, Water Resources Research Center, University of Hawaii, written commun., 1985.

${ }^{2}$ Estimated using regression model and adjusted area in table 2.
TABLE 6.-Predevelopment water budget for the area defined by a geographic information system, southern Oahu [In million gallons per day]

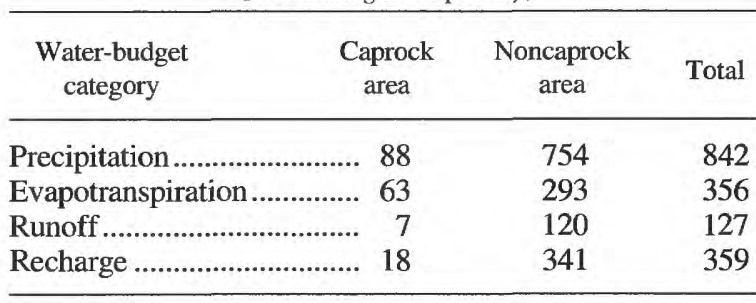

\section{SOUTHEASTERN OAHU}

A monthly water budget for part of the $28.4 \mathrm{mi}^{2}$ southeastern Oahu area (fig. 7) was calculated by Eyre and others (1986) as part of a ground-water flow analysis of that area. They did not simulate ground-water flow in the $3.29-\mathrm{mi}^{2}$ coastal-plain area southwest of Makapuu Head. Therefore, their water budget does not include the distribution of water in that part of southeastern Oahu. However, their budget provides the basis for the development of a simple estimation model for southeastern Oahu that is similar to the one developed for southern Oahu. Simple linear recharge-precipitation relations for 

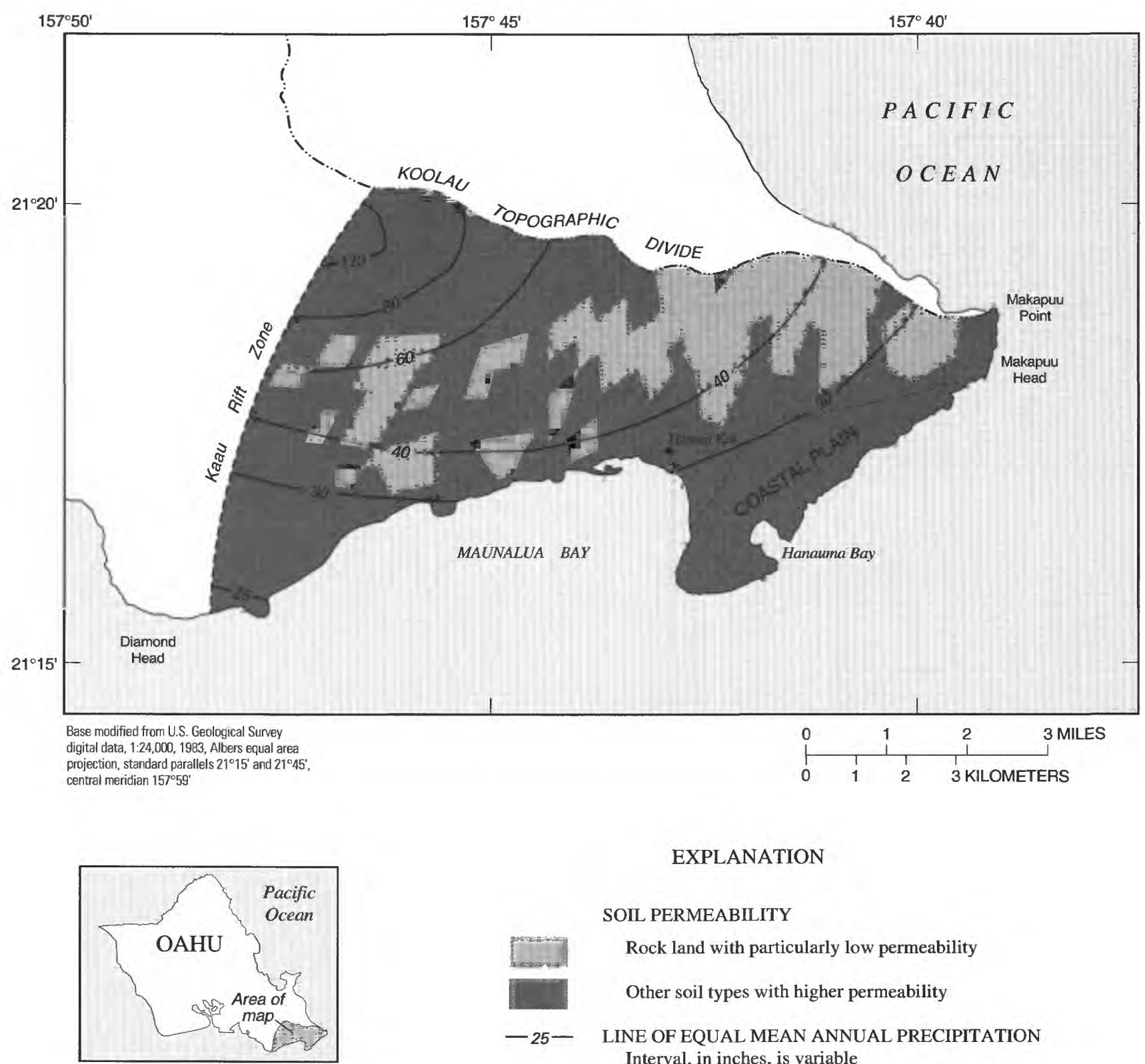

EXPLANATION

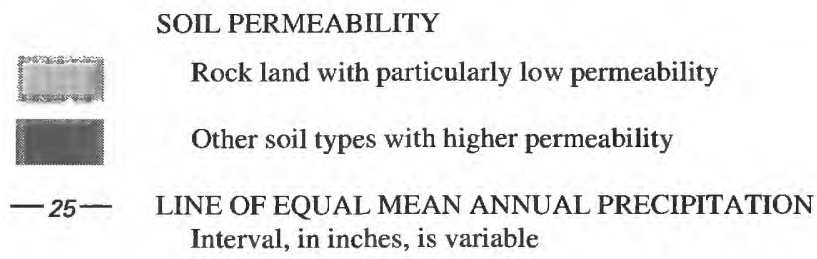

FIGURE 7.-Mean annual precipitation and areas of relatively low and high soil permeability, southeastern Oahu.

use in the GIS model were determined on the basis of the results of Eyre and others (1986). Two different relations were developed on the basis of relative soil permeabilities (fig. 8). Eyre and others (1986) distinguished 10 different soil types, based on data from Foote and others (1972), to account for the effects of variable soil properties, including permeability, on estimated recharge. The GIS model reduces these data to two relative soil types with high and low permeabilities, and uses a separate regression equation for each type to estimate recharge. Both equations are in the form of equation 1 , and the coefficients for the equations are listed in table 7. Table 8 lists the areas for each relative permeability soil type for a given mean annual precipitation zone in southeastern Oahu. Estimated ground-water recharge (in million gallons per day) was then determined by multiplying the appropriate recharge rate calculated with the regression equation by the area over which that rate applies.

A runoff-precipitation relation developed by Eyre and others (1986) was modified slightly and used to calculate runoff for southeastern Oahu. The equation used 
is the same form as equation 2 , and the coefficients are listed in table 9. The curve and data are shown in figure 9. Evapotranspiration was estimated to be the residual of precipitation minus runoff and recharge. The resulting predevelopment water budget determined by the simplified GIS model is compared with the results of Eyre and others (1986) in table 10. They estimated a total ground-water recharge of about $15 \mathrm{Mgal} / \mathrm{d}$ compared with about $19 \mathrm{Mgal} / \mathrm{d}$ estimated by using the GIS model in this study. The difference is attributed to the additional 4-Mgal/d mean annual precipitation estimated for the coastal-plain area by this study but that was not considered by Eyre and others (1986).
TABLE 7.-Regression equation coefficients for groundwater recharge, southeastern Oahu

$[a$, slope of regression line; $b$, regression line intercept at y axis; $r^{2}$, coefficient of determination]

\begin{tabular}{lrrr}
\multicolumn{4}{c}{$r$, coefficient of determination] } \\
\hline $\begin{array}{c}\text { Relative soil } \\
\text { permeability }\end{array}$ & $a$ & $b$ & $r^{2}$ \\
\hline Low ............................. & 0.501 & -13.32 & 0.91 \\
High ............................. & .927 & -16.74 & .85 \\
\hline
\end{tabular}

TABLE 8.-Areas for given relative soil permeability and mean annual precipitation, southeastern Oahu [in., inch; $\mathrm{mi}^{2}$, square mile; -, not applicable]

\begin{tabular}{ccc}
\hline & \multicolumn{2}{c}{ Area with indicated soil type $\left(\mathrm{mi}^{2}\right)$} \\
\cline { 2 - 3 } $\begin{array}{c}\text { Mean annual } \\
\text { precipitation } \\
\text { (in.) }\end{array}$ & $\begin{array}{c}\text { High } \\
\text { permeability }\end{array}$ & $\begin{array}{c}\text { Low } \\
\text { permeability }\end{array}$ \\
\hline 23.6 & 0.28 & - \\
27.6 & 7.1 & 0.57 \\
35.4 & 3.81 & 2.48 \\
49.2 & 5.17 & 4.59 \\
68.9 & 2.08 & .36 \\
98.4 & 1.65 & - \\
137.8 & .35 & - \\
Total............................. & 20.44 & 8.00 \\
\hline
\end{tabular}

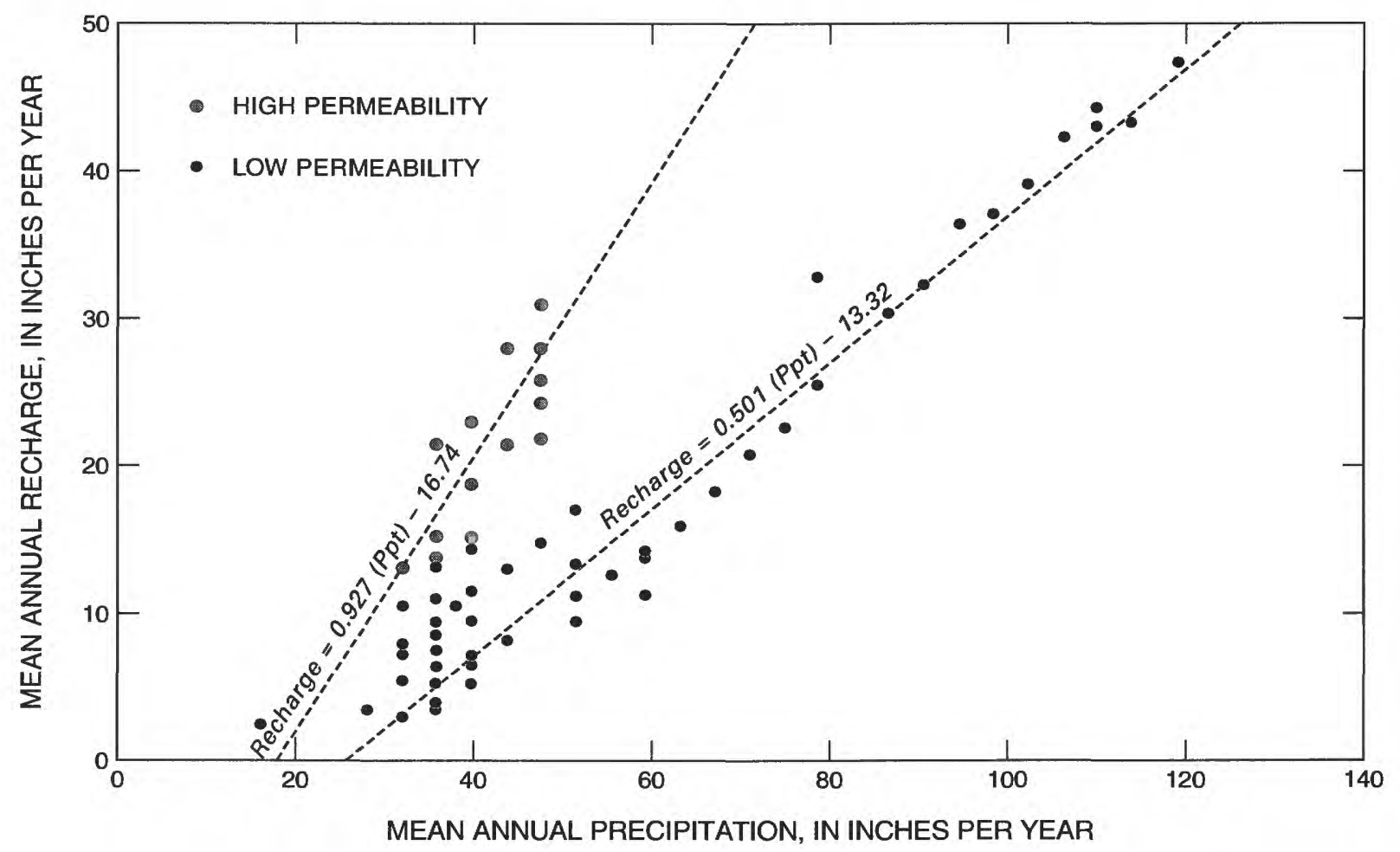

FIGURE 8.-Relation between precipitation and estimated ground-water recharge based on relative soil permeability, southeastern Oahu (data from Eyre and others, 1986).

$P p t$, mean annual precipitation. 


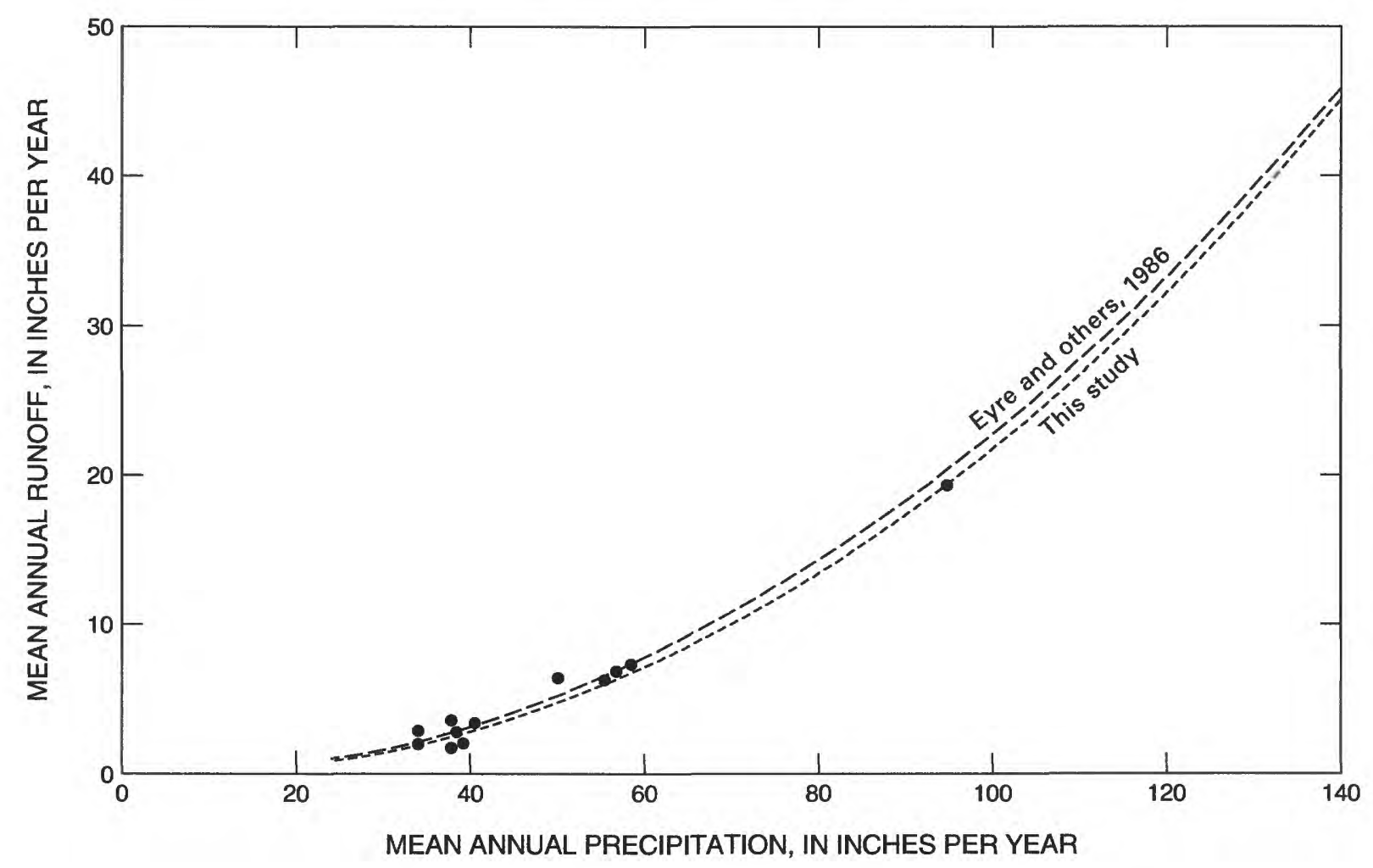

FIGURE 9.--Relation between precipitation and estimated runoff, southeastern Oahu.

\begin{tabular}{|c|c|c|}
\hline \multicolumn{3}{|c|}{ [All values in million gallons per day] } \\
\hline $\begin{array}{c}\text { Water-budget } \\
\text { category }\end{array}$ & $\begin{array}{l}\text { This } \\
\text { study }\end{array}$ & $\begin{array}{c}\text { Eyre and } \\
\text { others (1986) }\end{array}$ \\
\hline 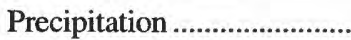 & 62 & 57 \\
\hline Evapotranspiration .................. & 36 & 36 \\
\hline Runoff & 7 & 6 \\
\hline Recharge & 19 & 15 \\
\hline
\end{tabular}

\section{WINDWARD OAHU}

Windward Oahu covers a little more than $124 \mathrm{mi}^{2}$ of the northeastern part of the island, east of the crest of the Koolau Range. Predevelopment water budgets for the 11 drainage basins of windward Oahu (fig. 10) were calculated by using methods similar to those of Takasaki and others (1969). The annual water budget is given by

$$
P p t-R-E T=G W,
$$

where $P p t$ is the mean annual precipitation, $R$ is mean annual direct runoff, $E T$ is mean annual evapotranspiration, and $G W$ is mean annual ground-water recharge.
Figure 10 shows the 11 drainage basins of windward Oahu and the mean annual precipitation (Giambelluca and others, 1986). Figure 11 shows the estimated mean annual evapotranspiration that was based on pan-evaporation data (Ekern and Chang, 1985). The name of each basin is given in table 11. Pan coefficients used to estimate actual evapotranspiration vary above and below 1.0, depending on the type of vegetation and time of year. For this study, which considers only mean annual conditions, the pan coefficient is assumed to be equal to 1.0 , and pan evaporation is assumed to equal mean annual evapotranspiration. Direct runoff is calculated as the difference between mean basin discharge and base flow and is expressed as a percentage of precipitation based on data from Takasaki and others (1969), Takasaki and Valenciano (1969), and the U.S. Geological Survey $(1970,1971,1972)$. The ratios are given in table 11.

The mean annual volume of precipitation for each basin was determined by multiplying the area by the mean annual precipitation that applies for that area (table 12). Evapotranspiration was estimated by multiplying the mean annual pan-evaporation rate by the area for which that rate applies (table 13). Direct runoff was determined by multiplying the volume of precipitation for the basin by the appropriate ratio from table 11 . Groundwater recharge was determined to be the residual of 


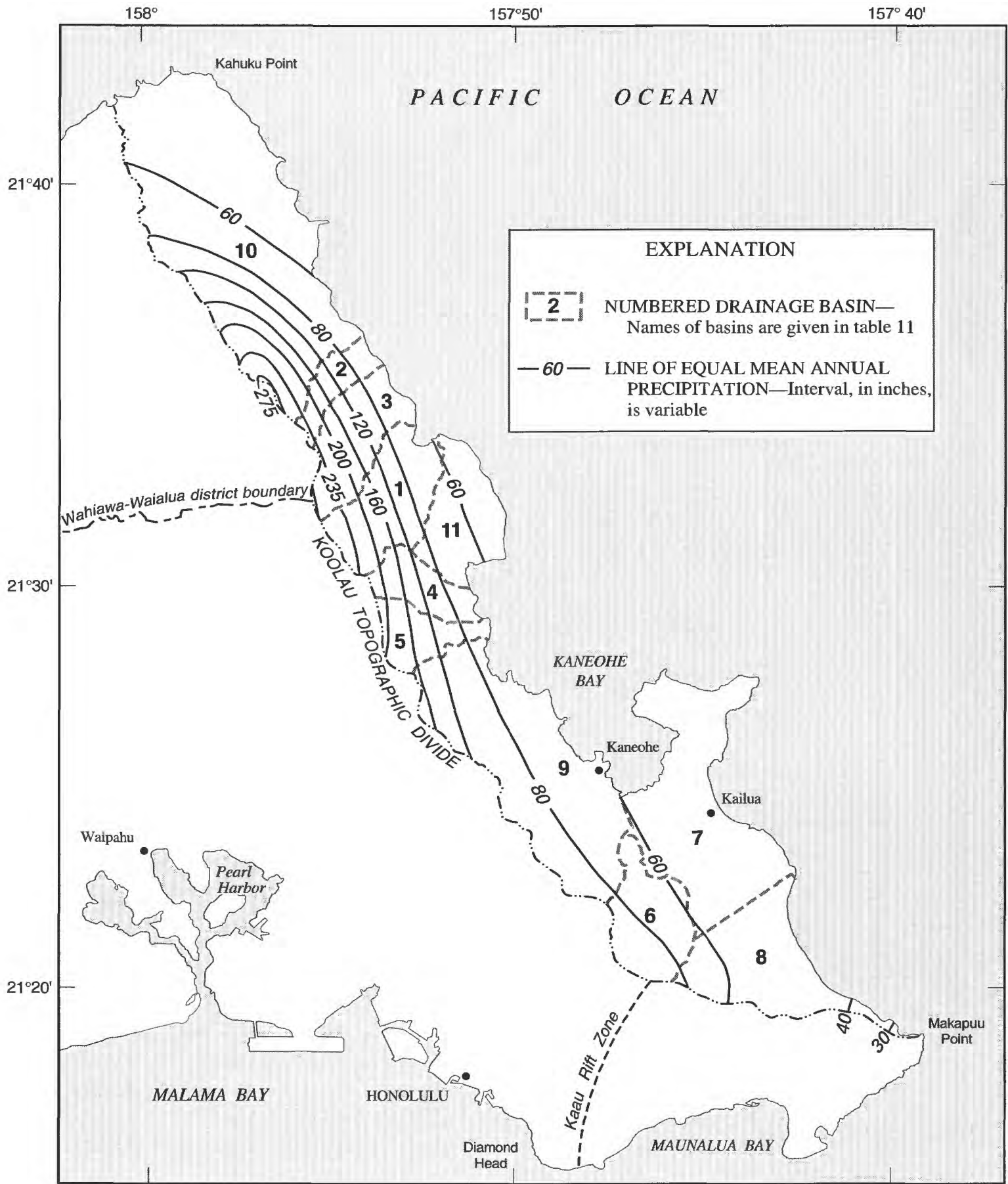

Base modified from U.S. Geological Survey digital data, 1:24,000, 1983, Albers equal area

projection, standard parallels $21^{\circ} 15^{\prime}$ and $21^{\circ} 45^{\prime}$

central meridian $157^{\circ} 59^{\prime}$
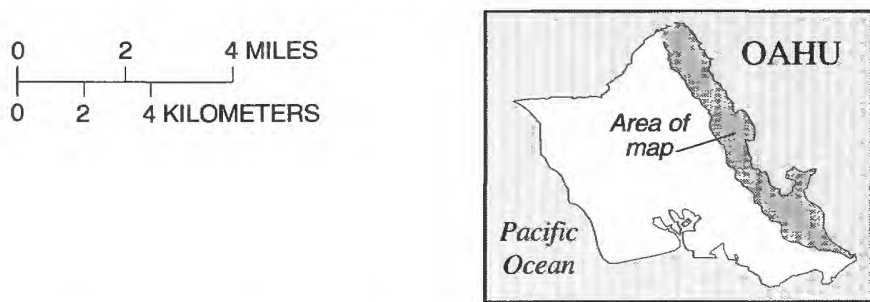

FIGURE 10.-Drainage basins and mean annual precipitation, windward Oahu. 


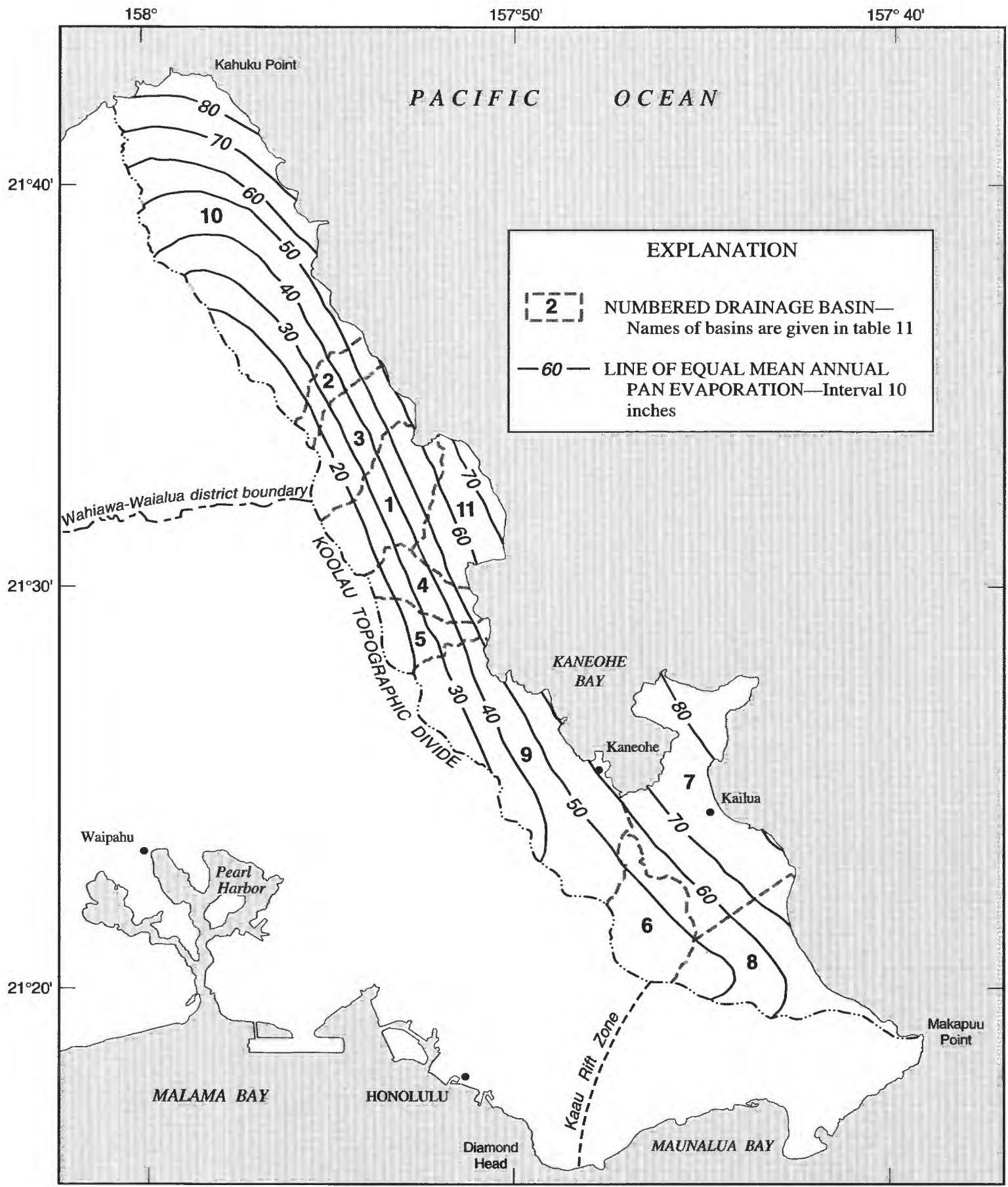

Base modified from U.S. Geological Survey digital data, 1:24,000, 1983, Albers equal area projection, standard parallels $21^{\circ} 15^{\prime}$ and $21^{\circ} 45^{\prime}$. central meridian 157 $59^{\prime}$
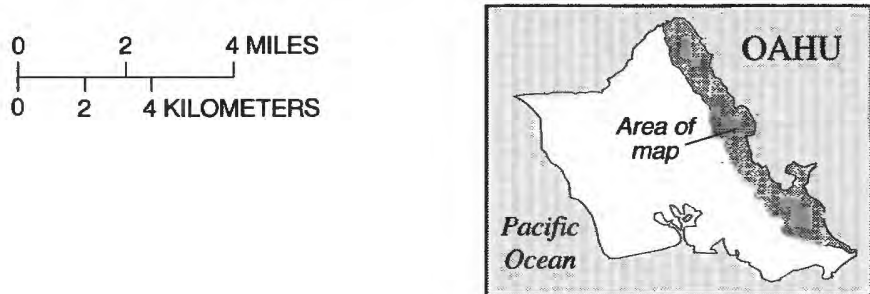

FIGURE 11.-Drainage basins and mean annual pan evaporation, windward Oahu (modified from Ekern and Chang, 1985). 
these three budget elements. The resulting water budgets for each basin are listed in table 14 .

The values for estimated evapotranspiration and recharge in table 14 derived from the GIS model cannot be duplicated for all basins with the data in tables 12 and 13. The GIS model makes use of smaller elements within each drainage basin. When evapotranspiration for any element of the GIS model equals or exceeds precipitation minus runoff, evapotranspiration cannot occur at the maximum rate and thus is set equal to precipitation minus runoff, and recharge is equal to zero.

\begin{tabular}{|c|c|c|}
\hline $\begin{array}{l}\text { Basin } \\
\text { no. } \\
\text { (fig. 10) }\end{array}$ & $\begin{array}{l}\text { Basin } \\
\text { name }\end{array}$ & $\begin{array}{c}\text { Runoff- } \\
\text { precipitation } \\
\text { ratio }\end{array}$ \\
\hline 1 & Kahana & $\ldots 0.26$ \\
\hline 2 & Kaluanui & ....... 23 \\
\hline 3 & Punaluu & ........16 \\
\hline 4 & Waikane & ....... 17 \\
\hline 5 & Waiahole & …......24 \\
\hline 6 & Maunawil & ...... 21 \\
\hline 7 & Kailua . & ...... .11 \\
\hline 8 & Waimanal & ....... 11 \\
\hline 9 & Kaneohe & .......17 \\
\hline 10 & Kahuku & .......20 \\
\hline 11 & Kaaawa/Hak & ...... 09 \\
\hline
\end{tabular}

Because the GIS model calculates the water budget for the smaller elements that compose each basin, using the total area given in tables 12 and 13 to estimate the total volume of precipitation and evapotranspiration yields no recharge for some basins; however, when using the smaller elements of the GIS model, some recharge is estimated.

Comparison of the GIS budgets with water budgets determined from previous studies is difficult because different boundaries were used to define study areas. Takasaki and others (1969, p. 85, 93, and 97) estimated water budgets for three basins included in their study of windward Oahu; these budgets are given in table 15 . The major difference between the previous estimates and the budgets calculated for this study is the estimated volume of precipitation. Part of the reason for this may be the different base period for mean annual precipitation used in the two studies; the base period for precipitation data used by Takasaki and others (1969) ranged from 1933 to 1957 and for the present study it ranged from 1916 to 1983 (Giambelluca and others, 1986). Similar values for evapotranspiration and runoff were obtained by both studies. The difference in precipitation estimated by each study results in similar differences in estimated ground-water recharge, which is to be expected because each study estimated recharge as a residual based on precipitation.

TABLE 12.-Areas for indicated mean annual precipitation, windward Oahu basins [Basins shown in fig. 10. in., inch; $\mathrm{mi}^{2}$, square mile; -, not applicable]

\begin{tabular}{|c|c|c|c|c|c|c|c|c|c|c|c|}
\hline Basin no. .......... & 1 & 2 & 3 & 4 & 5 & 6 & 7 & 8 & 9 & 10 & 11 \\
\hline $\begin{array}{l}\text { Mean annual } \\
\text { precipitation } \\
\text { (in.) }\end{array}$ & & & & & $\begin{array}{l}\text { Area } \\
\left(\mathrm{mi}^{2}\right)\end{array}$ & & & & & & \\
\hline 27.6 & - & - & 一 & - & - & - & - & 0.11 & 一 & - & - \\
\hline 35.4 & - & - & - & - & - & - & - & .33 & - & - & - \\
\hline 49.2 & 0.08 & - & - & - & - & 0.29 & 16.97 & 8.08 & - & 15.22 & 3.12 \\
\hline 68.9 & 2.41 & 0.71 & 1.44 & 0.64 & 0.34 & 3.73 & .38 & 1.86 & 9.40 & 8.78 & 2.89 \\
\hline 98.4 & 1.57 & .66 & 1.12 & 1.50 & .64 & 3.26 & - & .18 & 9.93 & 3.62 & - \\
\hline 137.8 & 1.02 & .42 & 1.05 & .91 & .97 & - & - & - & 1.94 & 2.55 & - \\
\hline 177.1 & 1.00 & .35 & .99 & .68 & 1.51 & - & - & - & .65 & 1.77 & - \\
\hline 216.5 & 1.23 & .40 & 1.22 & .36 & .45 & - & - & - & - & 1.96 & - \\
\hline 255.9 & 1.03 & .26 & .91 & - & - & - & 一 & - & - & 1.23 & - \\
\hline 275.6 & - & - & .10 & - & - & - & - & - & - & .25 & - \\
\hline Total............... & 8.34 & 2.80 & 6.83 & 4.09 & 3.91 & 7.28 & 17.35 & 10.56 & 21.92 & 35.38 & 6.01 \\
\hline
\end{tabular}


TABLE 13.-Areas for indicated mean annual pan evaporation, windward Oahu basins

[Basins shown in fig. 10. in, inch; $\mathrm{mi}^{2}$, square mile; —, not applicable]

\begin{tabular}{|c|c|c|c|c|c|c|c|c|c|c|c|}
\hline Basin no. ........... & 1 & 2 & 3 & 4 & 5 & 6 & 7 & 8 & 9 & 10 & 11 \\
\hline $\begin{array}{l}\text { Pan } \\
\text { evaporation } \\
\text { (in.) }\end{array}$ & & & & & $\begin{array}{l}\text { Area } \\
\left(\mathrm{mi}^{2}\right)\end{array}$ & & & & & & \\
\hline 18 & 1.83 & 0.42 & 1.52 & 0.38 & 1.54 & - & - & - & - & 2.92 & - \\
\hline 25 & 1.15 & .44 & 1.34 & .79 & 1.17 & - & - & - & 3.04 & 3.57 & - \\
\hline 35 & 1.43 & .64 & 1.41 & 1.48 & .69 & - & - & - & 4.69 & 5.27 & - \\
\hline 45 & 1.57 & .61 & 1.06 & 1.03 & .31 & 4.95 & - & 1.66 & 8.62 & 6.86 & 0.22 \\
\hline 55 & 1.81 & .68 & 1.18 & .41 & .20 & 2.33 & 1.50 & 3.74 & 5.06 & 5.16 & 1.66 \\
\hline 65 & .55 & .01 & .32 & - & - & - & 4.06 & 4.08 & .51 & 5.05 & 2.74 \\
\hline 75 & - & - & - & - & - & - & 8.76 & 1.08 & - & 4.52 & 1.39 \\
\hline \multirow[t]{2}{*}{82} & - & - & - & - & - & - & 3.03 & - & - & 2.03 & - \\
\hline & - & - & - & - & - & - & - & - & - & - & - \\
\hline Total ............. & 8.34 & 2.80 & 6.83 & 4.09 & 3.91 & 7.28 & 17.35 & 10.56 & 21.92 & 35.38 & 6.01 \\
\hline
\end{tabular}

TABLE 14.-Predevelopment water budgets, windward Oahu basins

[Basins shown in fig. 10. Mgal/d, million gallons per day; $\mathrm{mi}^{2}$, square mile]

\begin{tabular}{|c|c|c|c|c|c|c|c|c|c|c|c|c|}
\hline Basin no. & 1 & 2 & 3 & 4 & 5 & 6 & 7 & 8 & 9 & 10 & 11 & Total \\
\hline Precipitation (Mgal/d)..................... & 56 & 18 & 50 & 24 & 28 & 28 & 41 & 27 & 96 & 151 & 17 & 536 \\
\hline 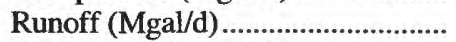 & 15 & 4 & 8 & 4 & 7 & 6 & 5 & 3 & 16 & 30 & 2 & 100 \\
\hline Evapotranspiration (Mgal/d).......... & 14 & 5 & 11 & 7 & 5 & 15 & 36 & 23 & 45 & 63 & 14 & 238 \\
\hline 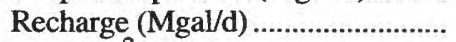 & 27 & 9 & 31 & 13 & 16 & 7 & 0 & 1 & 35 & 58 & 1 & 198 \\
\hline Area $\left(\mathrm{mi}^{2}\right)$ & 8.34 & 2.80 & 6.83 & 4.09 & 3.91 & 7.28 & 17.35 & 10.56 & 21.92 & 35.38 & 6.01 & 124.47 \\
\hline
\end{tabular}

\section{NORTH-CENTRAL OAHU}

The predevelopment water budget for north-central Oahu (fig. 12), which covers an area of slightly more than $121 \mathrm{mi}^{2}$, was modeled as an extension of southern Oahu because both areas have similar climate, topography, and soil types. Both have areas of caprock that affect recharge to the basalt aquifers, and both have large areas of irrigated agriculture that have altered the predevelopment ground-water recharge. The total volume of precipitation for caprock and noncaprock areas (fig. 1) of north-central Oahu was determined by multiplying the areas in table 16 by the appropriate value of annual precipitation.

Equation 1 was used with the coefficients in table 3 and the areas in table 16 to estimate ground-water recharge for predevelopment conditions in northcentral Oahu. Similarly, equation 2 and the coefficients in table 4 were used to calculate estimated runoff. Finally, as in southern Oahu, evapotranspiration was estimated to be the residual of precipitation minus runoff and recharge. The predevelopment water budget for caprock and noncaprock areas of northcentral Oahu is given in table 17.
The water budget for north-central Oahu, calculated with the GIS model for this study, is difficult to compare with budgets estimated by previous studies because of the difference in the boundaries of the study areas. The study by Rosenau and others (1971) covered $152 \mathrm{mi}^{2}$ of the north-central part of Oahu, but it excluded a small area west of the crest of the Koolau Range along the northern coast. They appear to have included some of the southern Oahu area (figs. $3 A, 4$ ); their location map is not detailed enough to ascertain the exact location of these boundaries.

TABLE 15.-Estimated water budgets for selected windward Oahu basins (from Takasaki and others, 1969) [Basins shown in fig. 10. Mgal/d, million gallons per day; $\mathrm{mi}^{2}$, square mile]

\begin{tabular}{|c|c|c|c|}
\hline Basin no. & 1 & 2 & 3 \\
\hline 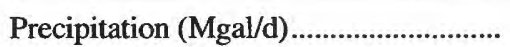 & 60 & 22 & 57 \\
\hline 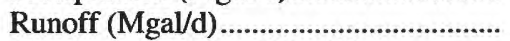 & 15 & 5 & 9 \\
\hline Evapotranspiration (Mgal/d)................... & 12 & 4 & 8 \\
\hline 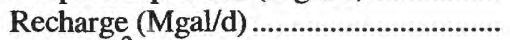 & 33 & 13 & 40 \\
\hline Area $\left(\mathrm{mi}^{2}\right)$ & 8.38 & 3.5 & 6.5 \\
\hline
\end{tabular}



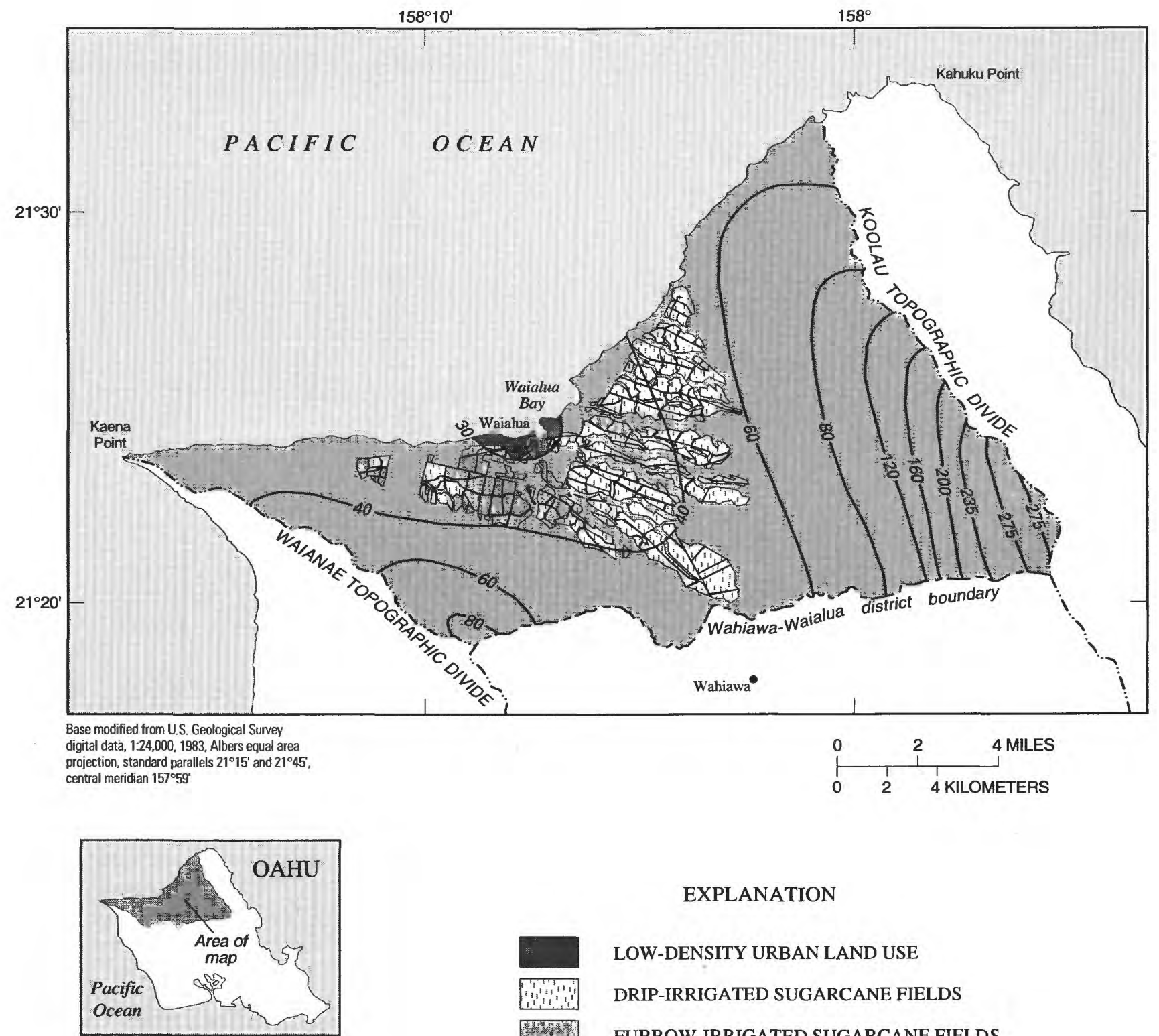

EXPLANATION
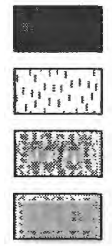

$-60-$
LOW-DENSITY URBAN LAND USE

DRIP-IRRIGATED SUGARCANE FIELDS

FURROW-IRRIGATED SUGARCANE FIELDS

NATURAL LAND USE

LINE OF EQUAL MEAN ANNUAL PRECIPITATION

Interval, in inches, is variable

FiGURE 12.-Mid-1980's land use and mean annual precipitation, north-central Oahu. 


\begin{tabular}{|c|c|c|c|}
\hline $\begin{array}{l}\text { Mean annual } \\
\text { precipitation } \\
\quad \text { (in.) }\end{array}$ & $\begin{array}{c}\text { Caprock } \\
\text { area } \\
\left(\mathrm{mi}^{2}\right)\end{array}$ & $\begin{array}{c}\text { Noncaprock } \\
\text { area } \\
\left(\mathrm{mi}^{2}\right)\end{array}$ & $\begin{array}{l}\text { Total } \\
\text { area } \\
\left(\mathrm{mi}^{2}\right)\end{array}$ \\
\hline 31.5 & 1.03 & - & 1.03 \\
\hline 35.43 & 10.92 & 16.72 & 27.64 \\
\hline 49.21 & 1.34 & 37.52 & 38.86 \\
\hline 68.9 & - & 26.75 & 26.75 \\
\hline 78.74 & - & .56 & .56 \\
\hline 98.42 & - & 9.92 & 9.92 \\
\hline 137.8 & - & 4.75 & 4.75 \\
\hline 177.2 & - & 3.77 & 3.77 \\
\hline 216.5 & - & 2.63 & 2.63 \\
\hline 255.9 & - & 3.32 & 3.32 \\
\hline 275.6 & - & 2.12 & 2.12 \\
\hline Total................ & .. 13.29 & 108.06 & 121.35 \\
\hline
\end{tabular}

TABLE 17.-Predevelopment water budget, north-central Oahu [In million gallons per day]

\begin{tabular}{|c|c|c|c|}
\hline $\begin{array}{l}\text { Water-budget } \\
\text { category }\end{array}$ & $\begin{array}{l}\text { Caprock } \\
\text { area }\end{array}$ & $\begin{array}{l}\text { Noncaprock } \\
\text { area }\end{array}$ & $\begin{array}{l}\text { Total } \\
\text { area }\end{array}$ \\
\hline Precipitation.. & .... 23 & 411 & 434 \\
\hline Runoff............ & .... 2 & 63 & 65 \\
\hline Evapotranspir & $\ldots .17$ & 168 & 185 \\
\hline Recharge........ & $\ldots .4$ & 180 & 184 \\
\hline
\end{tabular}

\section{WAIANAE AREA}

The Waianae area covers nearly $61 \mathrm{mi}^{2}$ of the western part of Oahu, west of the crest of the Waianae Range (figs. $3 A$ and 13). Climate, land cover, and soil types in this dry part of Oahu are similar to those of southeastern Oahu (fig. 7). Given the similarity of conditions, the ground-water recharge-precipitation and runoff-precipitation relations that were developed for southeastern Oahu were assumed to apply to the Waianae area as well. In addition to areas of low and high relative soil permeability, the Waianae area has extensive areas of algaroba (Prosopis chilensis), also called kiawe, which is a close relative of the mesquite of the Southwestern United States (Zones, 1963), and koa haole (Leucaena glauca), both of which are phreatophytes (fig. 13).

Little information is available on evapotranspiration rates for algaroba and koa haole. It is uncertain to what extent rates determined for similar plants in the Southwestern United States can be applied to the Waianae area. Zones (1963) estimated a ground-water discharge rate for these plants of from 3 to $6 \mathrm{ft} / \mathrm{yr}$. Examination of figure 13 indicates that most of these plants grow in areas that have a mean annual precipitation of less than about $35 \mathrm{in}$. The depth to ground water in these areas may be several hundred feet below land surface (Takasaki, 1971). Estimated annual runoff for this annual precipitation is about $2 \mathrm{in}$. On this basis, it is assumed that the evapotranspiration rate for these trees is about $33 \mathrm{in} / \mathrm{yr}$ and that, in areas of phreatophytes having a mean annual precipitation of $35 \mathrm{in}$. or less, no ground-water recharge occurs.

The volume of mean annual precipitation in the Waianae area was calculated by using the precipitation and area data in table 18. Equations 1 and 2, together with the regression coefficients given in tables 7 and 9 , were used to calculate ground-water recharge and runoff. Evapotranspiration was not allowed to exceed precipitation in any area and was estimated to be the residual of precipitation minus runoff and groundwater recharge. For phreatophyte areas (fig. 13) having a mean annual precipitation of less than 35 in., calculated recharge was assumed to be zero, and the precipitation minus runoff in these areas was distributed as evapotranspiration. The resulting predevelopment water budget for the Waianae area is given in table 19.

A complete water budget has not been estimated previously for the Waianae area. Takasaki (1971) estimated annual precipitation to be about $98 \mathrm{Mgal} / \mathrm{d}$; evapotranspiration, about $77 \mathrm{Mgal} / \mathrm{d}$; and runoff, about $15 \mathrm{Mgal} / \mathrm{d}$. An earlier study by Zones (1963) suggested that surfacewater discharge from the Waianae area was negligible (this study estimated $8 \mathrm{Mgal} / \mathrm{d}$ ), the consumptive use of ground water by phreatophytes ranged from about 5 to $10 \mathrm{Mgal} / \mathrm{d}$, and the total ground-water discharge by all means ranged from about 10 to $20 \mathrm{Mgal} / \mathrm{d}$. The present study estimated ground-water recharge, and, therefore, discharge, to be about $32 \mathrm{Mgal} / \mathrm{d}$.

The water budget developed by this study can be used to evaluate further the consumptive use of ground water by phreatophytes in the Waianae area and to estimate ground water that may discharge as underflow to the ocean. The assumptions made about evapotranspiration by phreatophytes at altitudes above about $100 \mathrm{ft}$ above sea level in the zone of 35 to $40 \mathrm{in}$. of mean annual precipitation imply that the phreatophytes growing there use between 33 and 38 in. of water per year. If about 35 in./yr is assumed to be a reasonable estimate for mean annual evapotranspiration by these phreatophytes, then phreatophytes growing in areas of lower mean annual precipitation, but in the presence of shallow ground water, will transpire at this same rate. The area covered by phreatophytes where mean annual precipitation is less than about $35 \mathrm{in} / \mathrm{yr}$ is about $11.5 \mathrm{mi}^{2}$ (table 18). (The estimated depth to ground water in higher mean annual precipitation zones appears to preclude these plants from using ground water.) The estimated phreatophyte evapotranspiration in this area is about $19 \mathrm{Mgal} / \mathrm{d}$. The calculated evapotranspiration in this area from the GIS 


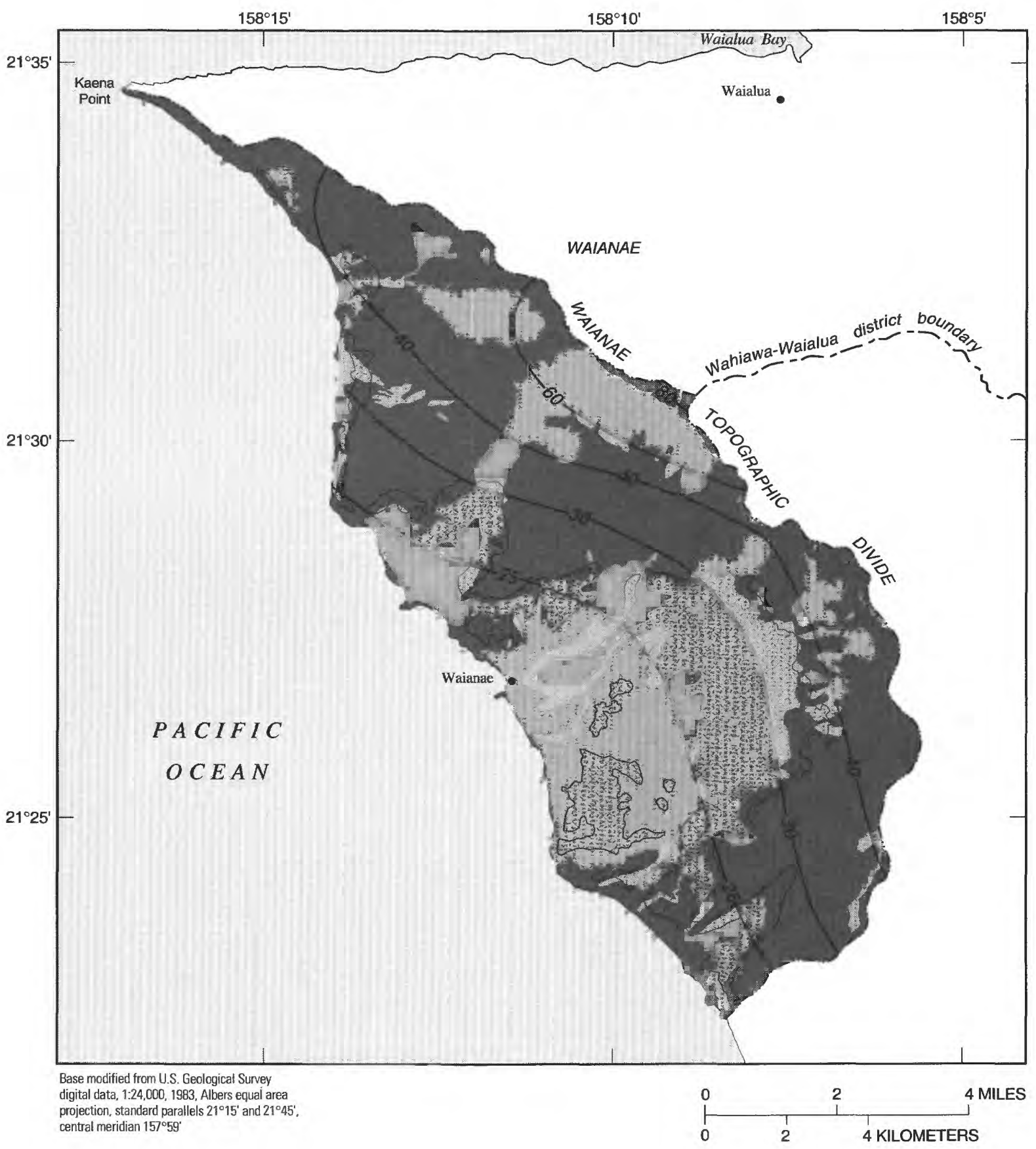

EXPLANATION

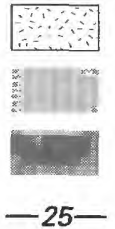

PHREATOPHYTE AREA

SOILS WITH LOW PERMEABILITY

SOILS WITH HIGH PERMEABILITY

-25- LINE OF EQUAL MEAN ANNUAL PRECIPITATIONInterval, in inches, is variable

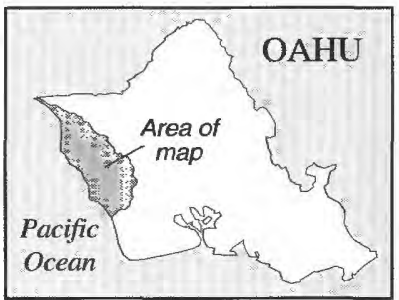

FIGURE 13.-Mean annual precipitation and areas of phreatophytes and of relatively low and high soil permeability, Waianae area, Oahu. 
TABLE 18.-Areas of phreatophyte and nonphreatophyte land cover and relative soil permeability for each precipitation zone, Waianae area, Oahu

[in., inch; $\mathrm{mi}^{2}$, square mile; -, not applicable]

\begin{tabular}{|c|c|c|c|c|c|c|c|}
\hline \multirow{2}{*}{$\begin{array}{l}\text { Mean annual } \\
\text { precipitation } \\
\quad \text { (in.) }\end{array}$} & \multicolumn{3}{|c|}{$\begin{array}{l}\text { Low-permeability } \\
\text { soils area }\left(\mathrm{mi}^{2}\right)\end{array}$} & \multicolumn{3}{|c|}{$\begin{array}{l}\text { High-permeability } \\
\text { soils area }\left(\mathrm{mi}^{2}\right)\end{array}$} & \multirow{2}{*}{$\begin{array}{l}\text { Total } \\
\left(\mathrm{mi}^{2}\right)\end{array}$} \\
\hline & $\begin{array}{l}\text { Non- } \\
\text { phreato- } \\
\text { phytes }\end{array}$ & $\begin{array}{l}\text { Phreato- } \\
\text { phytes }\end{array}$ & $\begin{array}{l}\text { Sub- } \\
\text { total }\end{array}$ & $\begin{array}{c}\text { Non- } \\
\text { phreato- } \\
\text { phytes }\end{array}$ & $\begin{array}{l}\text { Phreato- } \\
\text { phytes }\end{array}$ & $\begin{array}{l}\text { Sub- } \\
\text { total }\end{array}$ & \\
\hline 21.6 & 6.26 & 2.94 & 9.20 & 3.30 & 2.33 & 5.63 & 14.83 \\
\hline 27.6 & 2.16 & 4.91 & 7.07 & 5.96 & 1.28 & 7.24 & 14.31 \\
\hline 35.4 & 1.71 & 1.75 & 3.46 & 10.20 & .87 & 11.07 & 14.53 \\
\hline 49.2 & 3.49 & .13 & 3.62 & 9.79 & .18 & 9.97 & 13.59 \\
\hline 68.9 & 2.50 & - & 2.50 & 1.03 & - & 1.03 & 3.53 \\
\hline 78.7 & .01 & - & .01 & .11 & - & .11 & .12 \\
\hline 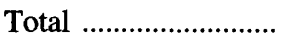 & 16.13 & 9.73 & 25.86 & 30.39 & 4.66 & 35.05 & 60.91 \\
\hline
\end{tabular}

TABLE 19.-Predevelopment water budget, Waianae area, Oahu [Mgal/d, million gallons per day]

\begin{tabular}{|c|c|}
\hline Water-budget category & $\mathrm{Mgal} / \mathrm{d}$ \\
\hline Precipitation .......... & ..... 103 \\
\hline 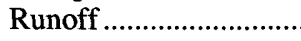 & 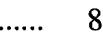 \\
\hline Evapotranspiration ....... & $\ldots .$. \\
\hline 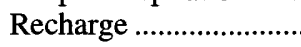 & $\ldots .$. \\
\hline
\end{tabular}

model is about $13 \mathrm{Mgal} / \mathrm{d}$. Therefore, the estimated ground-water consumption by phreatophytes that grow in these areas was about $6 \mathrm{Mgal} / \mathrm{d}$. Given the calculated recharge for the Waianae area of $32 \mathrm{Mgal} / \mathrm{d}$, the discharge of ground water by underflow to the ocean was then estimated to be about $26 \mathrm{Mgal} / \mathrm{d}$.

\section{ISLAND OF OAHU}

A summary predevelopment water budget for the island of Oahu was constructed from the budgets for the individual areas. This budget is given in table 20 . The only previous study that attempted to estimate a water budget for Oahu is that of Takasaki (1978). However, as with other previous studies, the boundaries of the various areas are different from those of the present study, so individual area budgets cannot be compared. Additionally, Takasaki's (1978) estimate of ground-water recharge in southern Oahu may have addressed only the noncaprock area and the 1950's or 1960's land-use conditions, which included significant irrigation-return flow components. The estimate of $6 \mathrm{Mgal} / \mathrm{d}$ for ground-water recharge in his budget for the Waianae area was based on estimated ground-water pumpage in that area rather than estimated recharge. For comparison, however, the island budget of Takasaki (1978) is given in table 21.

TABLE 20.-Predevelopment water budget, island of Oahu

[In million gallons per day]

\begin{tabular}{|c|c|c|c|c|c|c|}
\hline $\begin{array}{l}\text { Water-budget } \\
\text { category }\end{array}$ & $\begin{array}{l}\text { Southern } \\
\text { Oahu }\end{array}$ & $\begin{array}{c}\text { Southeastern } \\
\text { Oahu }\end{array}$ & $\begin{array}{l}\text { Windward } \\
\text { Oahu }\end{array}$ & $\begin{array}{c}\text { North- } \\
\text { Central Oahu }\end{array}$ & Waianae & Oahu \\
\hline 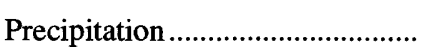 & 842 & 62 & 536 & 434 & 103 & 1,977 \\
\hline 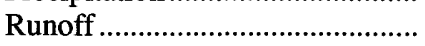 & 127 & 7 & 100 & 65 & 8 & 307 \\
\hline 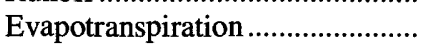 & 356 & 36 & 238 & 185 & 63 & 878 \\
\hline Recharge & 359 & 19 & 198 & 184 & 32 & 792 \\
\hline
\end{tabular}

TABLE 21.-Water budgets, island of Oahu [In million gallons per day]

\begin{tabular}{|c|c|c|}
\hline $\begin{array}{l}\text { Water-budget } \\
\text { category }\end{array}$ & $\begin{array}{l}\text { This } \\
\text { study }\end{array}$ & Takasaki $^{1}$ \\
\hline Precipitation .................. 1 & 1,977 & 1,800 \\
\hline 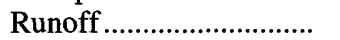 & 307 & 430 \\
\hline Evapotranspiration ......... & 878 & 715 \\
\hline 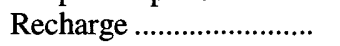 & 792 & 655 \\
\hline
\end{tabular}

'1978, p. M12. 


\section{DISTRIBUTION OF PREDEVELOPMENT GROUND-WATER RECHARGE}

Estimates of predevelopment ground-water recharge commonly are useful in studies of ground-water flow and development. The distribution of this recharge, as estimated by the GIS model, is given in table 22 and is shown in figure 14. This distribution may be analyzed further by developing a more detailed set of boundaries than have been used for estimating water budgets for the various study areas (fig. 15). The area boundaries shown in figure 15 are based on the boundaries shown in figure $3 B$. Some boundaries, notably the northern and southern Schofield ground-water barrier boundaries, have been extended to intersect topographic divides. Several small areas are defined by the intersections of the southwestern boundary of the Koolau Rift Zone and the topographic divide marking the crest of the Koolau Range. By using the GIS water-budget model, the recharge estimates made in this study can be aggregated by the areas shown in figure 15 (table 22 ), which, when combined in various patterns, may be comparable to areas described in previous investigations.

The distribution of predevelopment ground-water recharge to the noncaprock areas and ground-water underflow to the noncaprock basalt aquifers of southern and north-central Oahu are given in table 22 and are shown in figure 16. Of the 521-Mgal/d recharge to the noncaprock areas of southern and north-central Oahu, about $199 \mathrm{Mgal} / \mathrm{d}$ is derived from the Schofield ground-water area and those parts of the Koolau and the Waianae Rift Zones adjacent to the Schofield area (figs. $3 B, 16$ ). An estimated $111 \mathrm{Mgal} / \mathrm{d}$ moves into the Schofield area as underflow from the Koolau Rift Zone, and about 9 $\mathrm{Mgal} / \mathrm{d}$ moves as underflow from the Waianae Rift Zone. About $79 \mathrm{Mgal} / \mathrm{d}$ recharges the Schofield area directly from precipitation. About $103 \mathrm{Mgal} / \mathrm{d}$ is estimated to move as underflow from the southern Schofield area into the Pearl Harbor and the Ewa ground-water areas in southern Oahu; about $96 \mathrm{Mgal} / \mathrm{d}$ moves as underflow from the northern Schofield area into the Waialua ground-water area in north-central Oahu (figs. $3 B, 16$ ).

Predevelopment recharge and ground-water underflow to the Pearl Harbor ground-water area is estimated to total about $261 \mathrm{Mgal} / \mathrm{d}$ (fig. 16). This estimate assumes that $103 \mathrm{Mgal} / \mathrm{d}$ from the southern Schofield area enters the Pearl Harbor area; some water flows into the adjacent Ewa ground-water area to the west, but the flow is probably less than $1 \mathrm{Mgal} / \mathrm{d}$. Recharge and underflow to the Ewa area is estimated to be about 9
Mgal/d. Predevelopment recharge to the remaining areas of the southern Oahu study area totals about 71 $\mathrm{Mgal} / \mathrm{d}$. In north-central Oahu, predevelopment recharge and underflow to the Waialua ground-water area is estimated to total about $104 \mathrm{Mgal} / \mathrm{d}$; to the Kawailoa area, about $62 \mathrm{Mgal} / \mathrm{d}$; and to the Mokuleia area, about $14 \mathrm{Mgal} / \mathrm{d}$ (figs. $3 B, 16$ ). The distribution of predevelopment recharge to windward Oahu basins (fig. $3 A$ ), the Waianae area, and southeastern Oahu is shown in figure 17.

\begin{tabular}{|c|c|c|c|}
\hline $\begin{array}{c}\text { Area } \\
\text { (fig. 15) }\end{array}$ & $\begin{array}{c}\text { Caprock } \\
\text { area }\end{array}$ & $\begin{array}{c}\text { Noncaprock } \\
\text { area }\end{array}$ & Total \\
\hline 1 & - & 3.77 & 3.77 \\
\hline 2 & - & 193.67 & 193.67 \\
\hline 3 & 0.15 & 35.98 & 36.13 \\
\hline 4 & .78 & 25.67 & 26.45 \\
\hline 5 & .86 & 8.36 & 9.22 \\
\hline 6 & 1.84 & 5.12 & 6.96 \\
\hline 7 & .16 & 7.34 & 7.50 \\
\hline 8 & - & 1.31 & 1.31 \\
\hline 9 & - & 7.76 & 7.76 \\
\hline 10 & - & 7.69 & 7.69 \\
\hline 11 & - & 31.70 & 31.70 \\
\hline 12 & - & 8.94 & 8.94 \\
\hline 13 & - & 16.48 & 16.48 \\
\hline 14 & - & 64.09 & 64.09 \\
\hline 15 & - & 44.53 & 44.53 \\
\hline 16 & - & 33.14 & 33.14 \\
\hline 17 & .25 & 1.94 & 2.19 \\
\hline 18 & - & .37 & .37 \\
\hline 19 & - & .23 & .23 \\
\hline 20 & - & 9.78 & 9.78 \\
\hline 21 & - & 6.13 & 6.13 \\
\hline 22 & 2.71 & 6.76 & 9.47 \\
\hline 23 & 6.59 & 135.02 & 141.61 \\
\hline 24 & - & 22.79 & 22.79 \\
\hline 25 & 3.60 & 24.76 & 28.36 \\
\hline 26 & .75 & 15.97 & 16.72 \\
\hline 27 & 2.70 & 17.84 & 20.54 \\
\hline 28 & 1.20 & 10.40 & 11.60 \\
\hline 29 & .10 & 7.10 & 7.20 \\
\hline 30 & .40 & 8.90 & 9.30 \\
\hline 31 & - & 2.40 & 2.40 \\
\hline 32 & - & .51 & .51 \\
\hline 33 & - & .24 & .24 \\
\hline 34 & - & 1.68 & 1.68 \\
\hline 35 & - & .30 & .30 \\
\hline 36 & - & 0.0 & 0.0 \\
\hline Total ...... & 22.09 & 768.67 & 790.76 \\
\hline
\end{tabular}




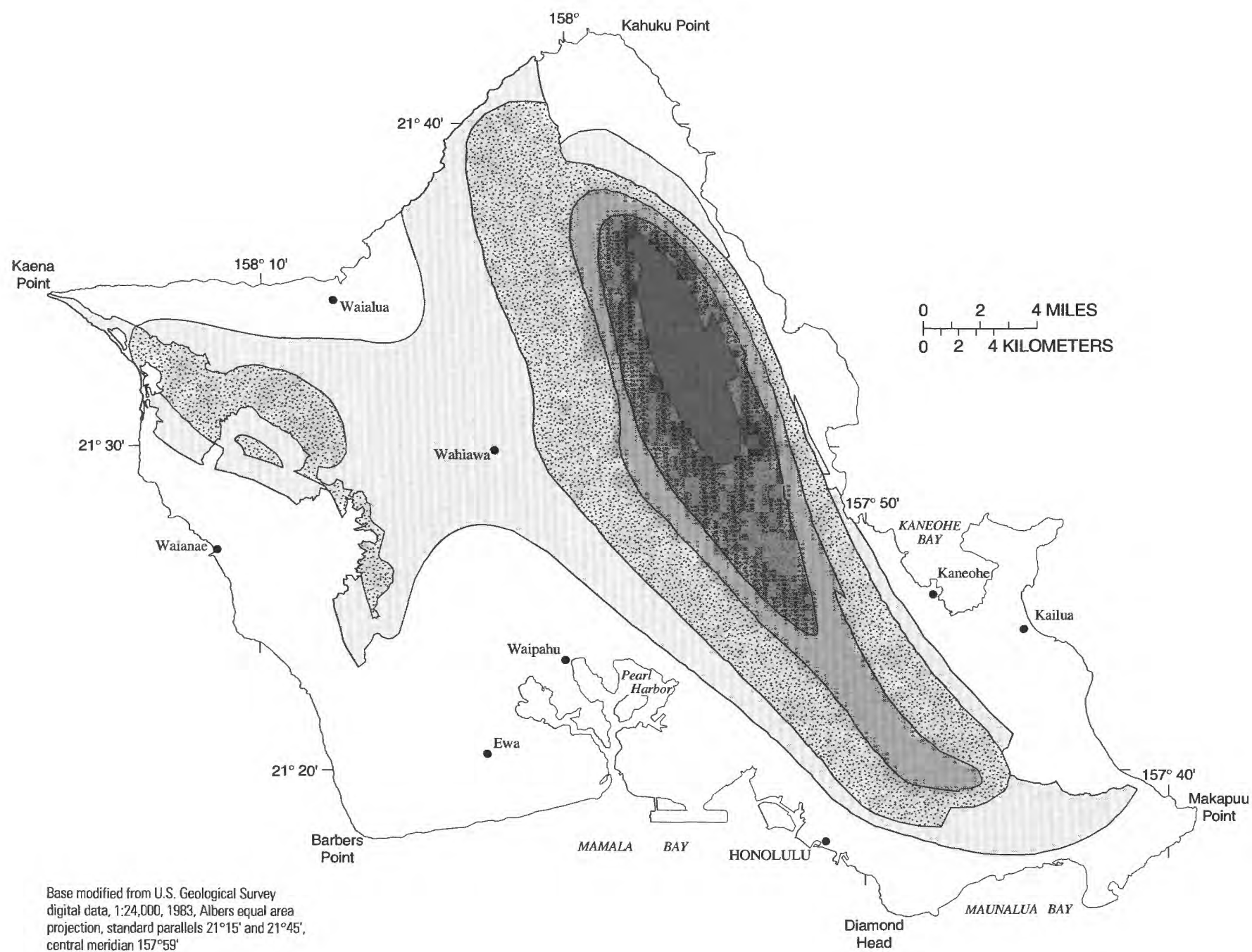

EXPLANATION

GROUND-WATER RECHARGE, IN INCHES PER YEAR

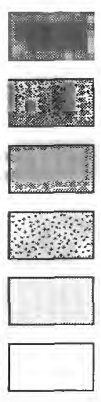

Greater than or equal to 150

Greater than or equal to 100 and less than 150

Greater than or equal to 50 and less than 100

Greater than or equal to 25 and less than 50

Greater than or equal to 10 and less than 25

Less than 10

FigURE 14.-Distribution of ground-water recharge for predevelopment land use, island of Oahu. 


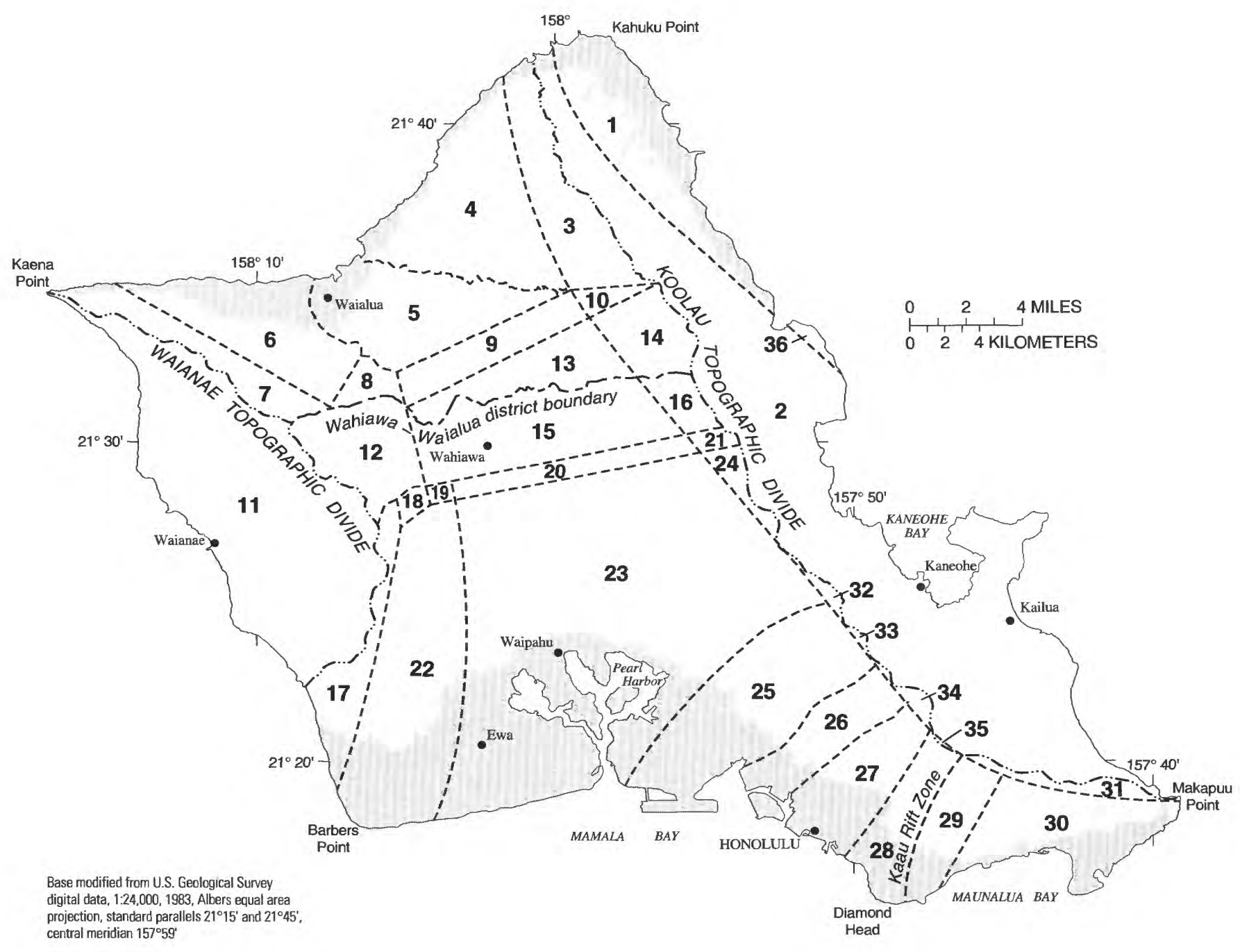

EXPLANATION

17 GROUND-WATER RECHARGE AREA AND NUMBER-

Numbers are area designations referenced in tables 22 and 30

COASTAL PLAIN (caprock)

FIGURE 15.-Ground-water recharge areas, island of Oahu. 


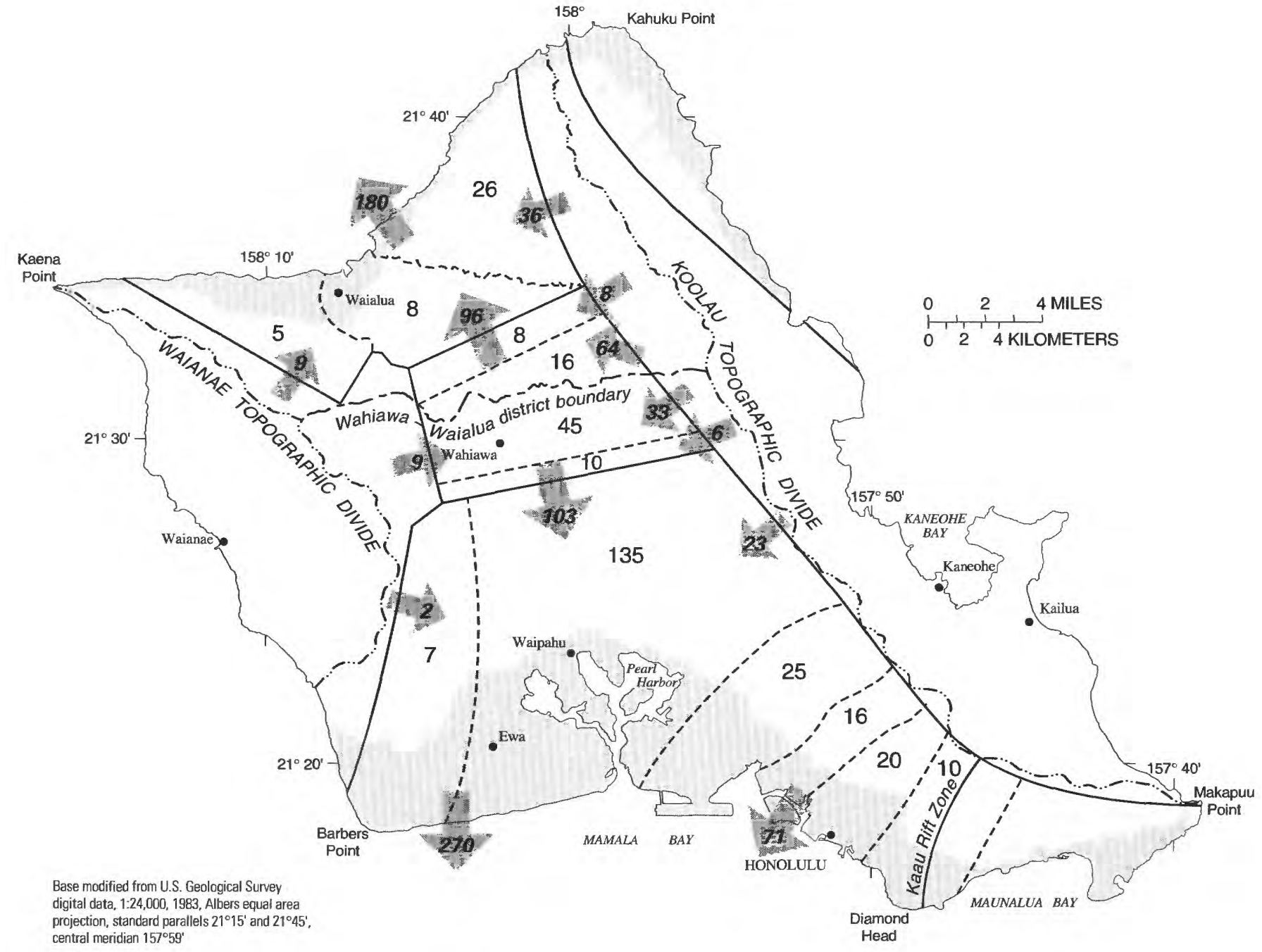

EXPLANATION

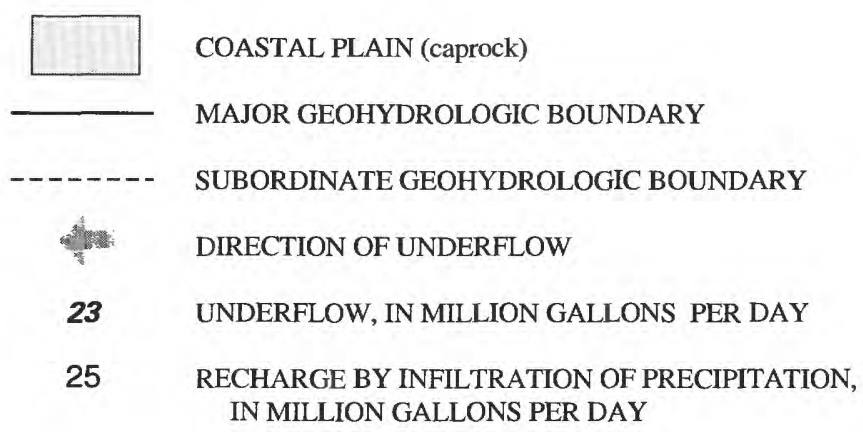

FIGURE 16.-Distribution of predevelopment recharge to and discharge from the noncaprock areas, southern and north-central Oahu. 


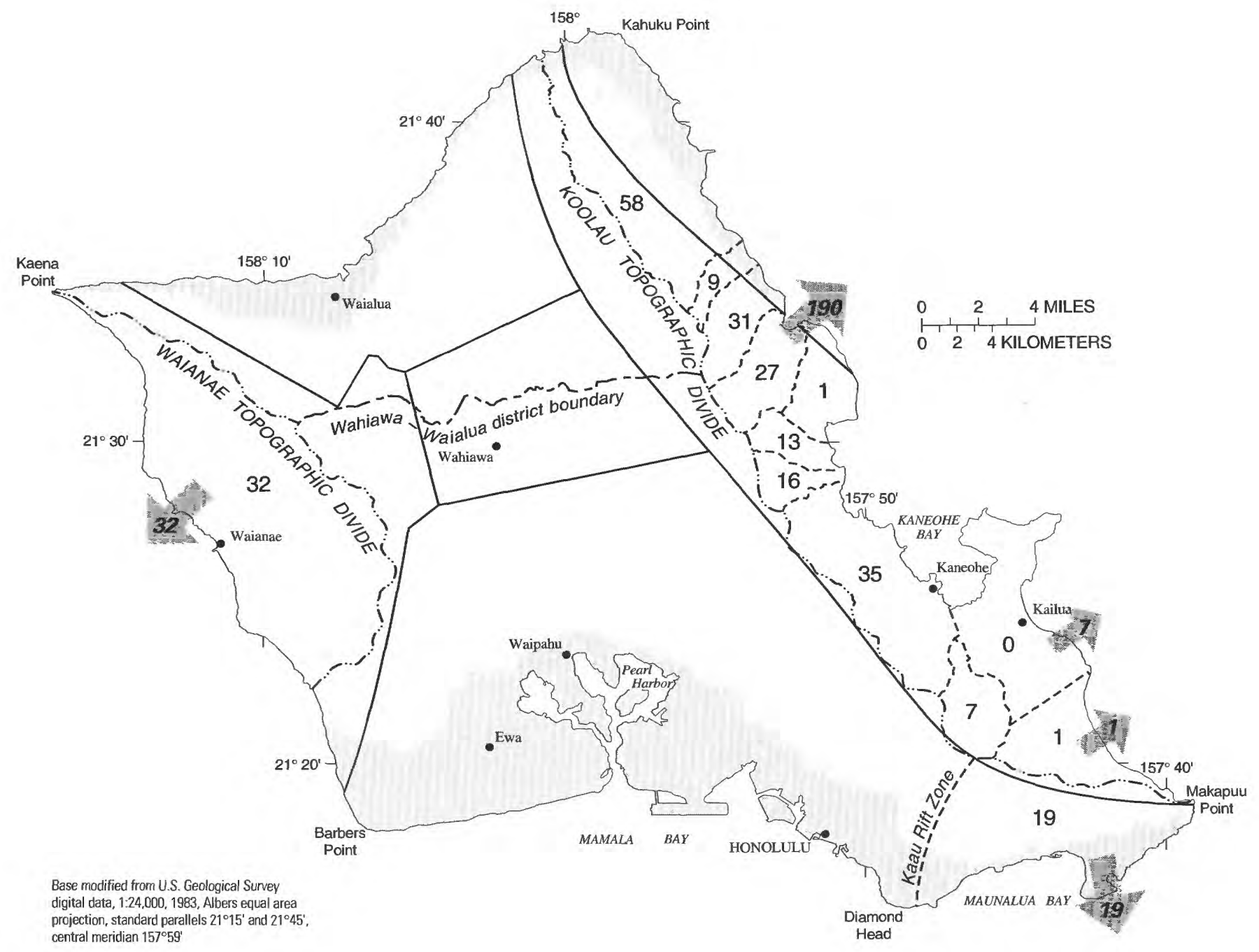

EXPLANATION

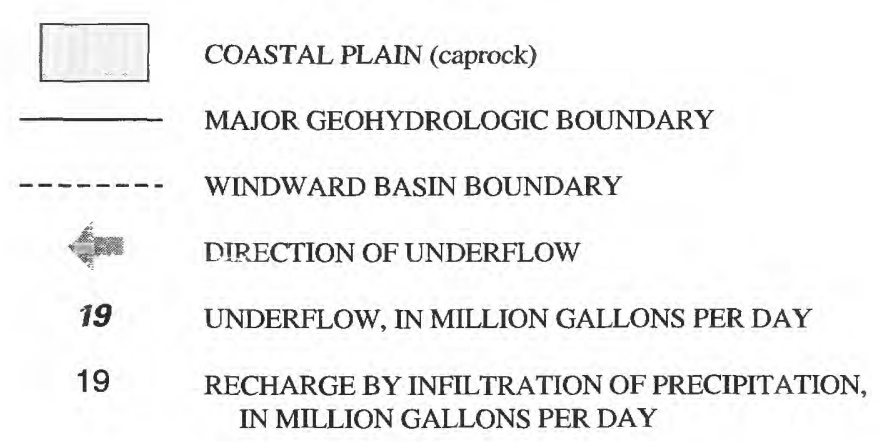

FIGURE 17.-Distribution of predevelopment recharge to and discharge from windward Oahu basins, Waianae area, and southeastern Oahu. 


\section{EFFECTS OF LAND-USE CHANGES ON GROUND-WATER RECHARGE}

Land-use changes affect the water budget through changes in evapotranspiration, runoff, and ground-water recharge. Low- to medium-density urbanization includes irrigation of lawns, gardens, and parks, which, in turn, increase water available at the land surface for increased evapotranspiration. Runoff increases and recharge in wet areas may be reduced, whereas recharge in dry areas may increase because of irrigation. Higher density urbanization enhances runoff, decreases evapotranspiration, and may increase recharge. Irrigated agriculture, however, has the greatest effect on the water budget. Applied irrigation water increases evapotranspiration, but irrigation practices seldom are efficient enough for all applied water to be consumed, and a significant percentage of the applied water recharges the underlying ground-water system.

The southern and north-central areas of Oahu have experienced the greatest changes in land use since the turn of the century. Although parts of southeastern and windward Oahu have undergone urbanization and small areas of windward Oahu have been cultivated, changes in these areas have affected the water budget less than the changes in the southern and north-central areas. The following discussion will concentrate on the changes in southern and north-central Oahu and the effect on ground-water recharge in these areas.

\section{SOUTHERN OAHU}

The effects of urbanization on ground-water recharge in southern Oahu can be evaluated by using the results of the detailed water-budget study by T.W. Giambelluca (1986; Water Resources Research Center, University of Hawaii, written commun., 1985). Recharge as a function of precipitation for natural and urban land uses during the mid-1980's is shown in figure 18. The major change in the relation is in areas that have less than about $60 \mathrm{in} / \mathrm{yr}$ of precipitation; these are the areas that have undergone the most urbanization. Consequently, a new set of coefficients for equation 1 was developed to reflect mid-1980's land-use practices. The coefficients given in table 23 and the areas listed in table 24 for the appropriate precipitation zone are used to calculate ground-water recharge for nonagricultural areas.

Ground-water recharge for mid-1980's agricultural land use also was estimated on the basis of the detailed

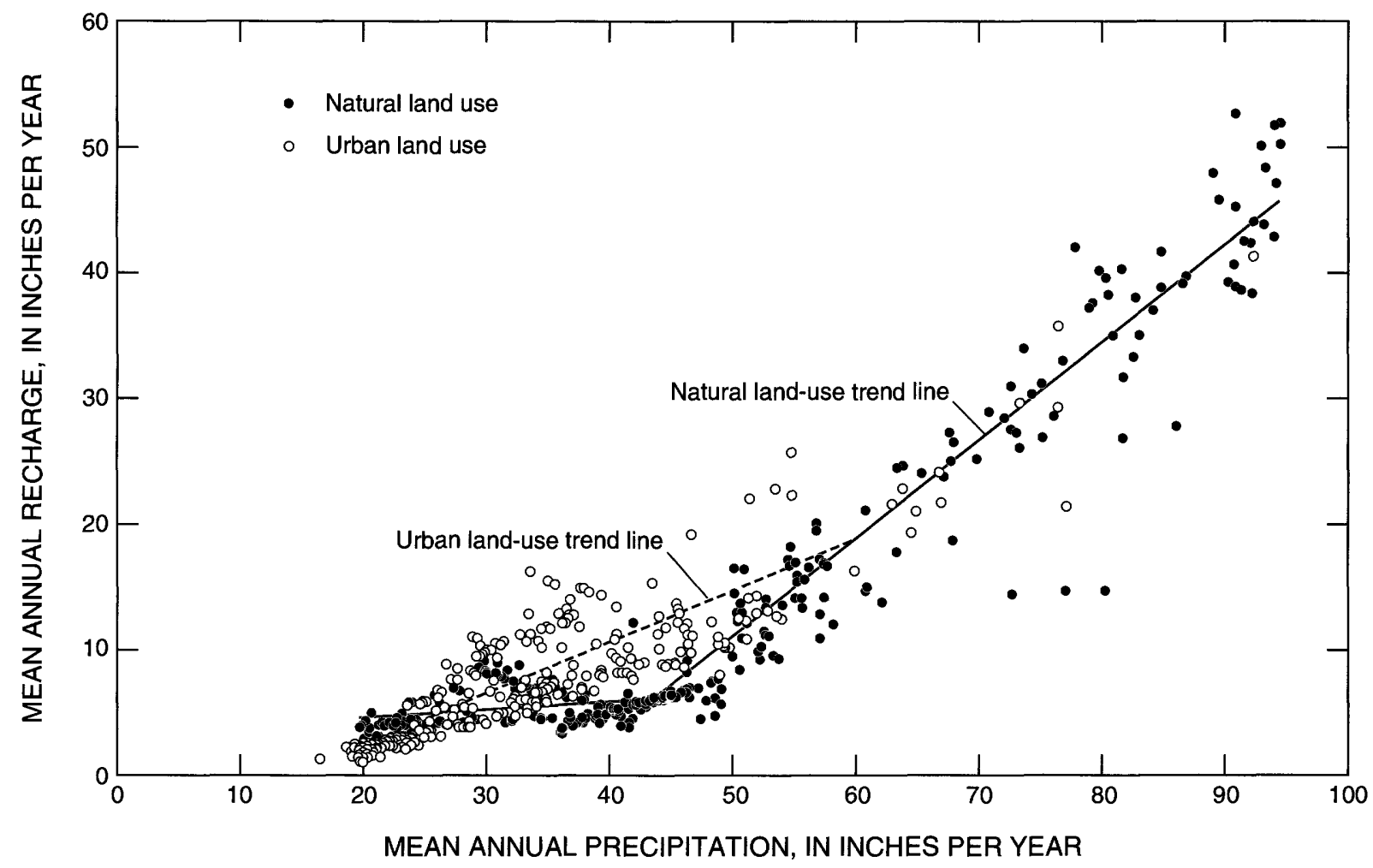

FIGURE 18.- Relation (general trend) between precipitation and estimated ground-water recharge for natural and urban land use during the mid-1980's, southern Oahu. 
studies of southern Oahu by Giambelluca $(1983,1986)$. Agricultural land use was subdivided into furrow-irrigated sugarcane, drip-irrigated sugarcane, and pineapple. Giambelluca $(1983,1986)$ suggested that an average of about $120 \mathrm{in} / \mathrm{yr}$ was applied in furrow-irrigated fields, and that recharge from furrow-irrigated sugarcane averaged $87.3 \mathrm{in} / \mathrm{yr}$ and accounted for 72.9 percent of the applied irrigation water (Giambelluca, 1983 , p. 105). By using data from T.W. Giambelluca (Water Resources Research Center, University of Hawaii, written commun., 1985), the present study developed a linear relation between precipitation and recharge in areas of drip-irrigated sugarcane (fig. 19). This relation is given by

$$
\operatorname{Rech}_{D S}=0.64(P p t)+11.1\left(r^{2}=0.89\right) \text {, }
$$

\begin{tabular}{l} 
TABLE 23.- Regression equation coefficients for ground- \\
water recharge for mid-1980's nonagricultural land use, \\
southern Oahu \\
[in., inch; a, slope of regression line; $b$, regression line intercept \\
at y axis; $r^{2}$, coefficient of determination; >, actual value is greater \\
than value shown] \\
\hline $\begin{array}{l}\text { Mean annual } \\
\text { precipitation } \\
\text { range (in.) }\end{array}$ \\
\hline
\end{tabular}

where Rech $_{D S}$ is the mean annual recharge, in inches, from drip-irrigated sugarcane; $P p t$ is the mean annual precipitation, in inches; and $\mathrm{r}^{2}$ is the coefficient of determination. The average applied water in drip-irrigated fields was about $65 \mathrm{in} / \mathrm{yr}$ (Giambelluca, 1983; 1986).

A similar relation was developed for areas of pineapple cultivation (fig. 20), given by

$$
\operatorname{Rech}_{P}=0.935(P p t)-13.54\left(r^{2}=0.98\right) \text {, }
$$

where $\operatorname{Rech}_{P}$ is the mean annual recharge, in inches, from pineapple.

Ground-water recharge for mid-1980's land use is compared with recharge for predevelopment conditions in table 25 and figure 21 . Recharge in noncaprock agricultural areas, which includes large amounts of irrigationreturn flow, increased $33 \mathrm{Mgal} / \mathrm{d}$ in the mid-1980's over predevelopment recharge to these same areas (table 25), and recharge to noncaprock, nonagricultural areas decreased about $1 \mathrm{Mgal} / \mathrm{d}$ from predevelopment to about $327 \mathrm{Mgal} / \mathrm{d}$. Total noncaprock recharge in the mid-1980's increased about $32 \mathrm{Mgal} / \mathrm{d}$ above predevelopment recharge.

The runoff-precipitation relation changed for mid1980's land use in areas that had a mean annual precipitation of less than about 130 in. (fig. 22). Runoff in these areas is calculated by using the linear regression equation 1 and the coefficients in table 26. The coefficients for the 20 - to $130-\mathrm{in} / \mathrm{yr}$ areas are based on a regression that uses runoff data for urban and natural

TABLE 24.-Areas of agricultural and nonagricultural land use during the mid-1980's, southern Oahu

\begin{tabular}{|c|c|c|c|c|c|c|c|c|c|}
\hline \multirow[b]{3}{*}{$\begin{array}{l}\text { Mean annual } \\
\text { precipitation } \\
\text { (in.) }\end{array}$} & \multicolumn{4}{|c|}{ Caprock area } & \multicolumn{5}{|c|}{ Noncaprock area } \\
\hline & \multicolumn{2}{|c|}{ Irrigated sugarcane } & \multirow[b]{2}{*}{$\begin{array}{l}\text { Nonagri- } \\
\text { cultural } \\
\left(\mathrm{mi}^{2}\right)\end{array}$} & \multirow[b]{2}{*}{$\begin{array}{l}\text { Total } \\
\left(\mathrm{mi}^{2}\right)\end{array}$} & \multicolumn{3}{|c|}{ Irrigated agriculture } & \multirow{2}{*}{$\begin{array}{l}\text { Nonagri- } \\
\text { cultural } \\
\left(\mathrm{mi}^{2}\right)\end{array}$} & \multirow[b]{2}{*}{$\begin{array}{l}\text { Total } \\
\left(\mathrm{mi}^{2}\right)\end{array}$} \\
\hline & $\begin{array}{l}\text { Drip } \\
\left(\mathrm{mi}^{2}\right)\end{array}$ & $\begin{array}{c}\text { Furrow } \\
\left(\mathrm{mi}^{2}\right)\end{array}$ & & & $\underset{\left(\mathrm{mi}^{2}\right)}{\text { Drip }}$ & $\begin{array}{c}\text { Furrow } \\
\left(\mathrm{mi}^{2}\right)\end{array}$ & $\begin{array}{c}\text { Pineapple } \\
\left(\mathrm{mi}^{2}\right)\end{array}$ & & \\
\hline 21.65 & 11.40 & 2.25 & 27.62 & 41.27 & 0.06 & 0.07 & - & 5.47 & 5.60 \\
\hline 23.62 & - & - & 1.21 & 1.21 & - & - & - & - & - \\
\hline 27.56 & 1.70 & - & 14.49 & 16.19 & 3.91 & 1.46 & 0.69 & 10.19 & 16.25 \\
\hline 35.43 & - & - & 9.41 & 9.41 & 3.56 & - & 3.81 & 15.96 & 23.33 \\
\hline 49.21 & - & - & 1.59 & 1.59 & .20 & - & 10.31 & 41.42 & 51.93 \\
\hline 68.90 & - & - & .91 & .91 & - & - & 3.11 & 15.40 & 18.51 \\
\hline 78.74 & - & - & - & - & - & - & - & .63 & .63 \\
\hline 98.42 & - & - & .02 & .02 & - & - & .31 & 27.66 & 27.97 \\
\hline 137.80 & - & - & - & - & - & - & - & 21.01 & 21.01 \\
\hline 157.50 & - & 一 & - & - & - & - & - & 1.17 & 1.17 \\
\hline 177.20 & - & - & - & - & - & - & - & 13.22 & 13.22 \\
\hline 216.50 & - & - & - & - & - & - & - & 6.06 & 6.06 \\
\hline 255.90 & 一 & - & - & - & - & - & - & 3.95 & 3.95 \\
\hline 275.60 & - & - & - & - & - & - & - & .23 & .23 \\
\hline Total ............. & 13.10 & 2.25 & 55.25 & 70.60 & 7.73 & 1.53 & 18.23 & 162.37 & 189.86 \\
\hline
\end{tabular}
[in., inch; $\mathrm{mi}^{2}$, square mile; -, not applicable] 


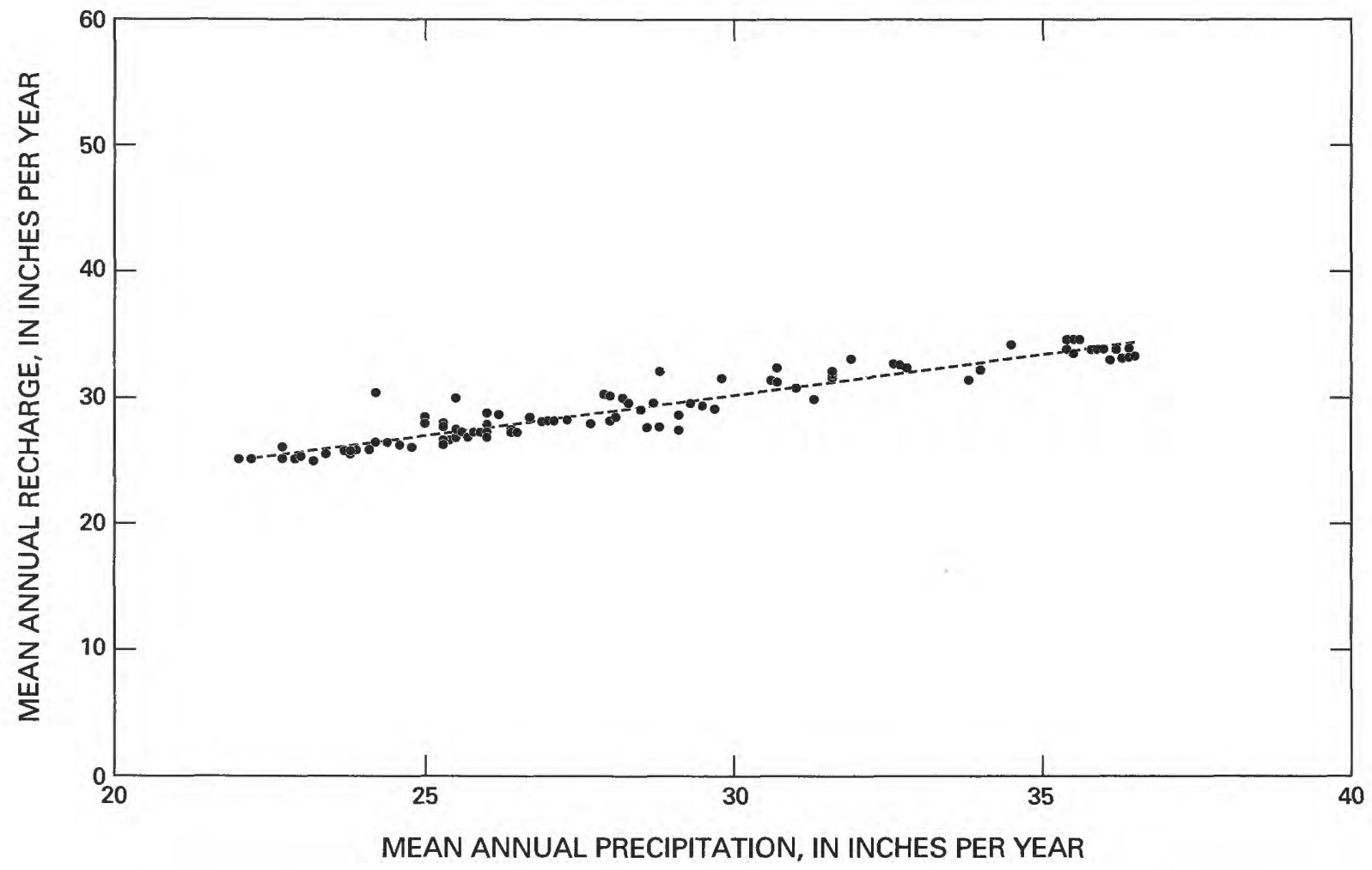

FIGURE 19.-Relation (general trend) between precipitation and estimated ground-water recharge in areas of drip-irrigated sugarcane during the mid-1980's, southern Oahu.

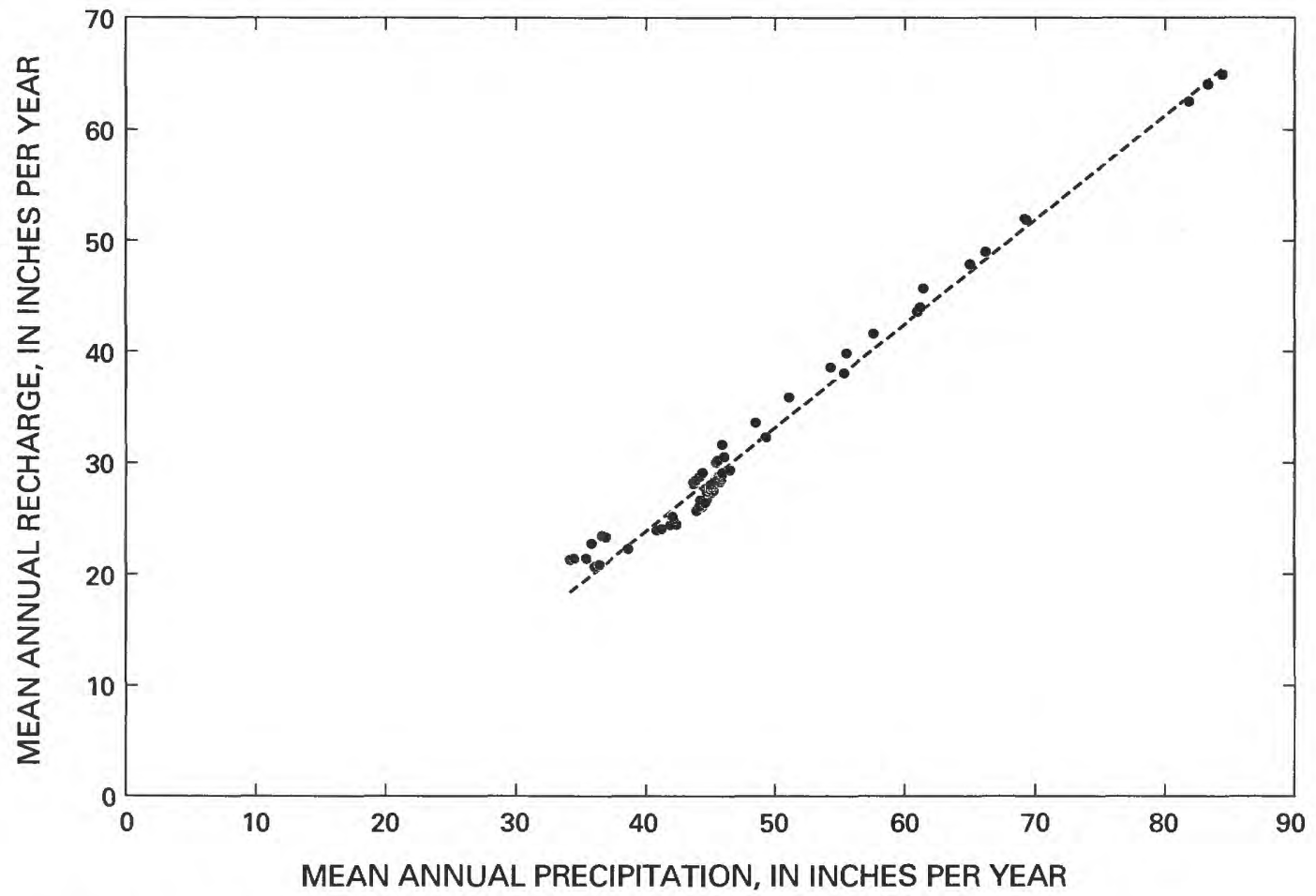

FIGURE 20.--Relation (general trend) between precipitation and estimated ground-water recharge in areas of pineapple cultivation during the mid-1980's, southern Oahu. 
land uses (fig. 22). For areas having more than 130 in/yr of precipitation, runoff is calculated by using the power regression equation 2 and the appropriate coefficients in table 26.

To estimate a mid-1980's water budget for southern Oahu, applied irrigation water reported by T.W. Giambelluca (Water Resources Research Center, University of Hawaii, written commun., 1985) was added to precipitation, and then recharge and runoff were subtracted to estimate evapotranspiration as a residual. Estimated runoff increased by about 18 percent above predevelopment runoff rates to about $150 \mathrm{Mgal} / \mathrm{d}$. Es- timated recharge increased by about $56 \mathrm{Mgal} / \mathrm{d}$ (15 percent above predevelopment rates) to about 415 $\mathrm{Mgal} / \mathrm{d}$, but only by about $32 \mathrm{Mgal} / \mathrm{d}$ (9 percent) to about $373 \mathrm{Mgal} / \mathrm{d}$ in the hydrologically important noncaprock area. Evapotranspiration increased by about $8 \mathrm{Mgal} / \mathrm{d}$ above predevelopment rates. The water budget is given in table 27.

The irrigation-return flow estimates for furrow-irrigated sugarcane by Giambelluca $(1983,1986)$ are considerably higher than those of previous investigators (Dale, 1967; Mink, 1980; Eyre and Nichols, in press). Giambelluca (1983, p. 105) estimated an irrigation-re-

TABLE 25.-Predevelopment and mid-1980's recharge to indicated areas of mid-1980's

land use, southern Oahu

[In million gallons per day; -, not applicable]

\begin{tabular}{|c|c|c|c|c|c|c|}
\hline \multirow[b]{2}{*}{$\begin{array}{l}\text { Mid-1980's } \\
\text { land use }\end{array}$} & \multicolumn{3}{|c|}{ Predevelopment $^{1}$} & \multicolumn{3}{|c|}{ Mid-1980's } \\
\hline & Caprock & $\begin{array}{l}\text { Non- } \\
\text { caprock }\end{array}$ & Total & Caprock & $\begin{array}{c}\text { Non- } \\
\text { caprock }\end{array}$ & Total \\
\hline Sugarcane ................ & 4 & 2 & 6 & 27 & 17 & 44 \\
\hline Pineapple.................. & $\ldots-$ & 11 & 11 & - & 29 & 29 \\
\hline Nonagricultural...... & ... 14 & 328 & 342 & 15 & 327 & 342 \\
\hline Total ............................ & ... 18 & 341 & 359 & 42 & 373 & 415 \\
\hline
\end{tabular}

${ }^{1}$ Predevelopment recharge to indicated mid-1980's land-use area.

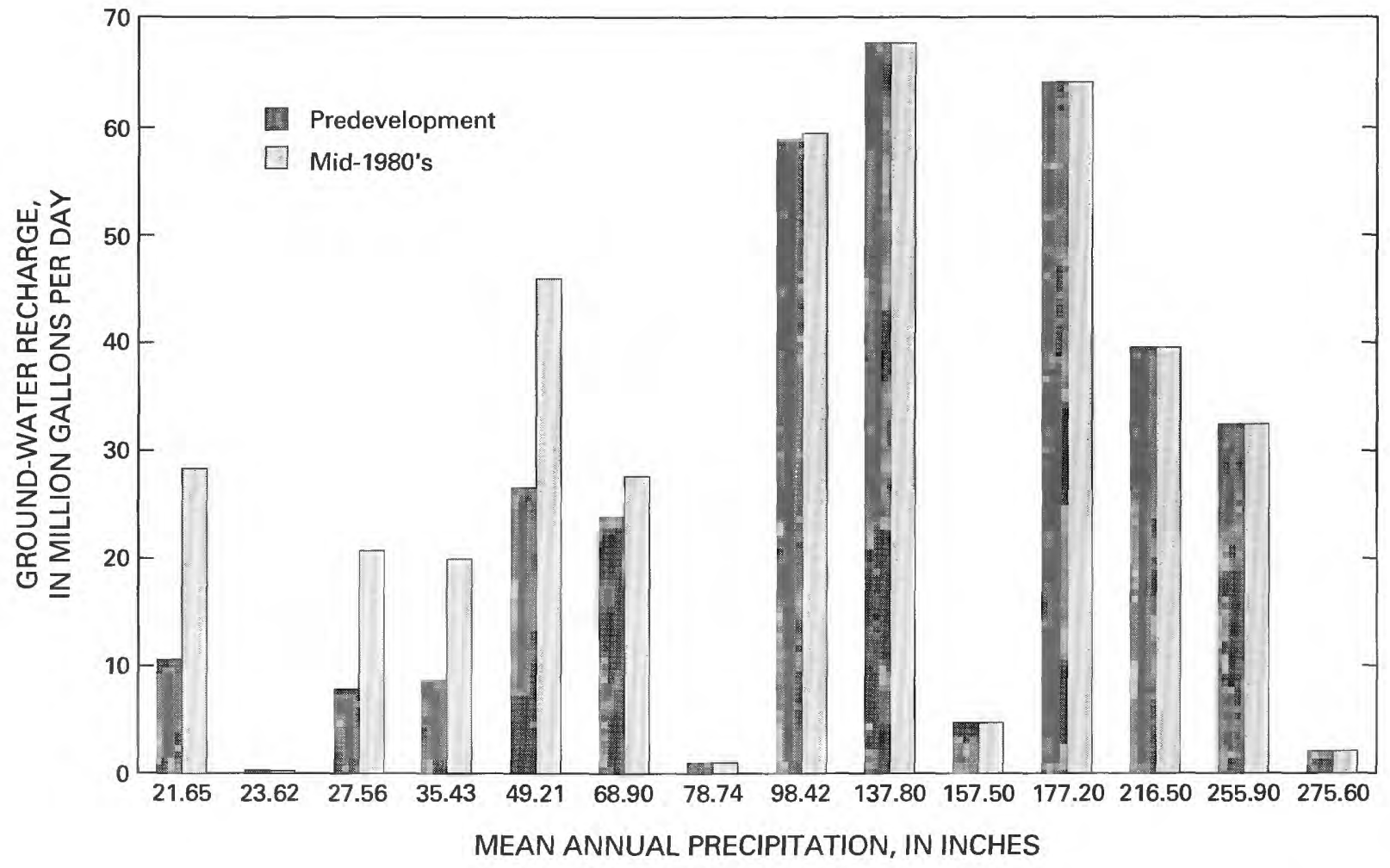

FIGURE 21.-Estimated ground-water recharge for predevelopment and mid-1980's land use, southern Oahu. 
turn flow of about $6.4 \mathrm{ft} / \mathrm{yr}$. Dale (1967) estimated an annual return-flow rate of $3.5 \mathrm{ft} / \mathrm{yr}$, and Mink [1980, cited by Giambelluca (1983, p. 104)] estimated an annual rate of about $5.2 \mathrm{ft} / \mathrm{yr}$. A numerical analysis of the southern Oahu ground-water flow system, which is part of the Hawaii RASA study, estimated an annual returnflow rate of about $3.6 \mathrm{ft} / \mathrm{yr}$ (Eyre and Nichols, in press). Giambelluca (1983, p. 105-106) discussed the differences from earlier studies and suggested that previous investigators may have overestimated evapotranspiration and, thereby, underestimated recharge.
The detailed studies of Giambelluca $(1983,1986)$ represent a more rigorous approach to estimating evapotranspiration and irrigation-return flow for furrow-irrigated sugarcane than previous investigations, but the numerical analysis by Eyre and Nichols (in press) suggests that this more rigorous approach may not have yielded more accurate estimates. Giambelluca (1983, p. 103) concluded that evapotranspiration from sugarcane was about $4.4 \mathrm{ft} / \mathrm{yr}$. Campbell and others (1959, p. 644) concluded from lysimeter studies in sugarcane

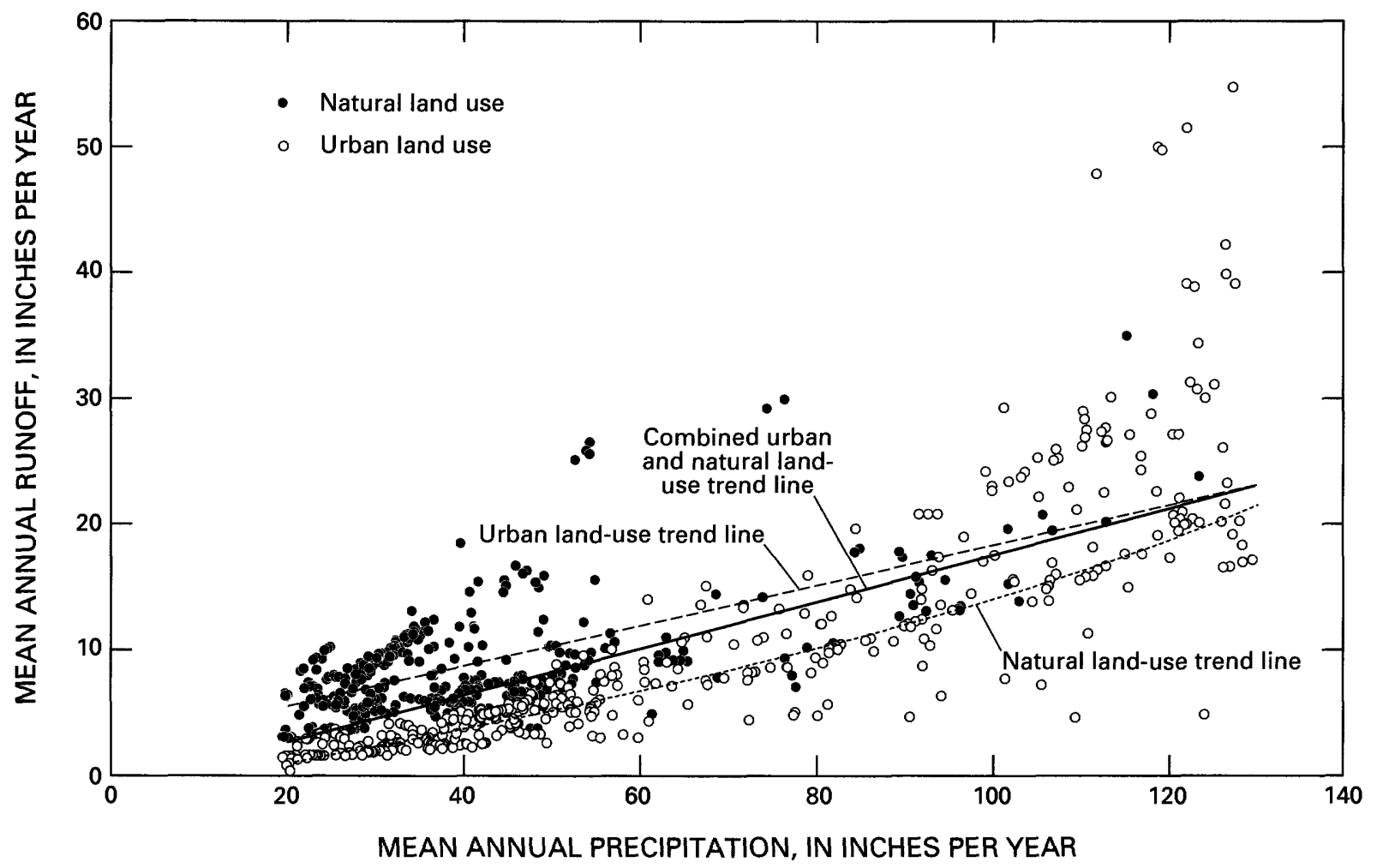

FIGURE 22.-Relation (general trends) between precipitation and estimated runoff for natural and urban land uses during the mid-1980's, southern Oahu.

TABLE 26--Regression equation coefficients for runoff for mid-1980's land use, southern Oahu

[in., inch; $a$ and $b$, regression coefficients; $r^{2}$, coefficient of determination; - , not applicable; $>$, actual value is greater than value shown]

\begin{tabular}{cccr}
\hline $\begin{array}{l}\text { Mean annual } \\
\text { precipitation } \\
\text { range (in.) }\end{array}$ & $a$ & $b$ & $r^{2}$ \\
\hline${ }^{1} 20-130$ & 0.185 & -1.022 & 0.59 \\
$2130-175$ & .013 & 1.536 & .92 \\
$3_{175-200}^{2}$ & - & - & .91 \\
2 & & & \\
\hline
\end{tabular}

${ }^{1}$ Coefficients for equation 1.

${ }^{2}$ Coefficients for equation 2 .

${ }^{3}$ Constant 37.5 in. used to connect power function curves.
TABLE 27.-Water budget for mid-1980's land use, southern Oahu [n million gallons per day]

\begin{tabular}{|c|c|c|c|}
\hline $\begin{array}{l}\text { Water-budget } \\
\text { category }\end{array}$ & $\begin{array}{c}\text { Caprock } \\
\text { area }\end{array}$ & $\begin{array}{c}\text { Noncaprock } \\
\text { area }\end{array}$ & Total \\
\hline 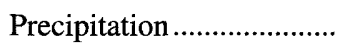 & 88 & 754 & 842 \\
\hline Applied irrigation................ & 54 & 33 & 87 \\
\hline 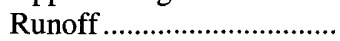 & 13 & 137 & 150 \\
\hline Evapotranspiration ............. & 87 & 277 & 364 \\
\hline 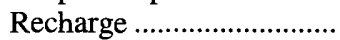 & 42 & 373 & 415 \\
\hline
\end{tabular}


fields on the island of Maui that sugarcane evapotranspired about $6.8 \mathrm{ft} / \mathrm{yr}$. This is $2.4 \mathrm{ft} / \mathrm{yr}$ more than estimated by Giambelluca (1983) and would reduce the estimated irrigation-return flow rate to about $4 \mathrm{ft} / \mathrm{yr}$, which is close to the estimates made by previous investigators. This also would reduce recharge from furrow-irrigated sugarcane in southern Oahu by about $5 \mathrm{Mgal} / \mathrm{d}$ for mid-1980's acreages, of which about $2 \mathrm{Mgal} / \mathrm{d}$ was in the noncaprock area. For the present study, the estimates of return-flow recharge from furrow-irrigated sugarcane of $16 \mathrm{Mgal} / \mathrm{d}$, of which $6 \mathrm{Mgal} / \mathrm{d}$ was to the noncaprock area, have a relatively small effect on the total mid-1980's recharge estimates for southern Oahu. The rates developed during previous studies would suggest recharge to caprock and noncaprock areas from furrow-irrigated sugarcane of about $8 \mathrm{Mgal} / \mathrm{d}$.

Recharge from irrigation-return flow from drip-irrigated sugarcane cultivation similarly may be too high because of the estimated rate of sugarcane evapotranspiration used by Giambelluca (1983). Recharge during the mid-1980's in areas of drip-irrigated sugarcane cultivation in southern Oahu amounts to nearly $29 \mathrm{Mgal} / \mathrm{d}$, which is an increase of $24 \mathrm{Mgal} / \mathrm{d}$ over predevelopment recharge rates to the same area; of this, $11 \mathrm{Mgal} / \mathrm{d}$ was in the noncaprock area and represents an increase of 9 $\mathrm{Mgal} / \mathrm{d}$ over predevelopment recharge rates to these areas. This is 60 percent of the estimated increase in recharge to the noncaprock area planted in sugarcane compared with predevelopment conditions. However, increasing sugarcane evapotranspiration by $2.4 \mathrm{ft} / \mathrm{yr}$ reduces recharge in drip-irrigated sugarcane areas by about $29 \mathrm{Mgal} / \mathrm{d}$ in southern Oahu and by about 11 $\mathrm{Mgal} / \mathrm{d}$ in the noncaprock area.
Total recharge for the agricultural areas of southern Oahu (caprock and noncaprock areas) in the mid-1980's was estimated to be about $73 \mathrm{Mgal} / \mathrm{d}$ (table 25). However, if estimated evapotranspiration by sugarcane is increased from 4.4 to $6.8 \mathrm{ft} / \mathrm{yr}$, then recharge in these areas is reduced by about $34 \mathrm{Mgal} / \mathrm{d}$ to about 39 $\mathrm{Mgal} / \mathrm{d}$. Mid-1980's recharge in sugarcane areas may be overestimated by a factor of two if the evapotranspiration rate for sugarcane is more accurately estimated to be $6.8 \mathrm{ft} / \mathrm{yr}$. It is, however, beyond the scope of this study to estimate the appropriate evapotranspiration rate for sugarcane. This is a problem that deserves serious consideration because of the resulting effects on ground-water recharge estimates.

\section{NORTH-CENTRAL OAHU}

A water budget for mid-1980's conditions for north-central Oahu was estimated by using the equations and coefficients for recharge and runoff for southern Oahu with the appropriate precipitation zones and land-use areas given in table 28. An estimated rate of applied irrigation water for sugarcane was based on the rates of T.W. Giambelluca (Water Resources Research Center, University of Hawaii, written commun., 1985) for southern Oahu. No change was made to estimated recharge or runoff for nonagricultural areas because the only urbanized area in north-central Oahu has a mean annual precipitation of less than $30 \mathrm{in}$. Recharge in areas of irrigated sugarcane was estimated by using the same estimated recharge rates for southern Oahu. As

TABLE 28.-Areas of agricultural and nonagricultural land use during the mid-1980's, north-central Oahu [in., inch; $\mathrm{mi}^{2}$, square mile; -, not applicable]

\begin{tabular}{|c|c|c|c|c|c|c|c|c|}
\hline \multirow{3}{*}{$\begin{array}{l}\text { Mean annual } \\
\text { precipitation } \\
\text { (in.) }\end{array}$} & \multicolumn{4}{|c|}{ Caprock area } & \multicolumn{4}{|c|}{ Noncaprock area } \\
\hline & \multicolumn{2}{|c|}{ Irrigated sugarcane } & \multirow{2}{*}{$\begin{array}{c}\text { Nonagri- } \\
\text { cultural } \\
\left(\mathrm{mi}^{2}\right)\end{array}$} & \multirow[b]{2}{*}{$\begin{array}{l}\text { Total } \\
\left(\mathrm{mi}^{2}\right)\end{array}$} & \multicolumn{2}{|c|}{ Irrigated sugarcane } & \multirow{2}{*}{$\begin{array}{l}\text { Nonagri- } \\
\text { cultural } \\
\left(\mathrm{mi}^{2}\right)\end{array}$} & \multirow[b]{2}{*}{$\begin{array}{l}\text { Total } \\
\left(\mathrm{mi}^{2}\right)\end{array}$} \\
\hline & $\begin{array}{l}\text { Drip } \\
\left(\mathrm{mi}^{2}\right)\end{array}$ & $\begin{array}{l}\text { Furrow } \\
\left(\mathrm{mi}^{2}\right)\end{array}$ & & & $\begin{array}{l}\text { Drip } \\
\left(\mathrm{mi}^{2}\right)\end{array}$ & $\begin{array}{c}\text { Furrow } \\
\left(\mathrm{mi}^{2}\right)\end{array}$ & & \\
\hline 31.50 & 0.11 & 0.12 & 0.80 & 1.03 & - & - & - & - \\
\hline 35.43 & .99 & 2.27 & 7.66 & 10.92 & 5.54 & 1.07 & 10.11 & 16.72 \\
\hline 49.21 & - & - & 1.34 & 1.34 & 6.75 & - & 30.77 & 37.52 \\
\hline 68.90 & - & - & - & - & - & - & 26.75 & 26.75 \\
\hline 78.74 & - & - & - & - & - & - & .56 & .56 \\
\hline 98.42 & - & - & - & - & - & 一 & 9.92 & 9.92 \\
\hline 137.08 & - & - & - & - & - & - & 4.75 & 4.75 \\
\hline 177.20 & - & - & - & - & - & - & 3.77 & 3.77 \\
\hline 216.50 & - & - & - & - & - & - & 2.63 & 2.63 \\
\hline 255.90 & - & - & - & - & - & - & 3.32 & 3.32 \\
\hline 275.60 & - & - & - & - & - & - & 2.12 & 2.12 \\
\hline Total ........... & 1.10 & 2.39 & 9.80 & 13.29 & 12.29 & 1.07 & 94.70 & 108.06 \\
\hline
\end{tabular}


with the estimates of recharge in irrigated sugarcane areas of southern Oahu, the estimates for north-central Oahu also may be too high. The estimated water budget given in table 29 can be compared with predevelopment recharge given in table 17.

TABLE 29.-Estimated water budget for mid-1980's land use, north-central Oahu

[In million gallons per day]

\begin{tabular}{|c|c|c|c|}
\hline $\begin{array}{l}\text { Water-budget } \\
\text { category }\end{array}$ & $\begin{array}{c}\text { Caprock } \\
\text { area }\end{array}$ & $\begin{array}{c}\text { Noncaprock } \\
\text { area }\end{array}$ & Total \\
\hline Precipitation & 23 & 411 & 434 \\
\hline Applied irrigation..................... & 12 & 47 & 59 \\
\hline Runoff ................................... & 2 & 62 & 64 \\
\hline Evapotranspiration .................. & 19 & 194 & 213 \\
\hline 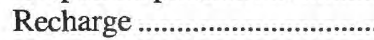 & 14 & 202 & 216 \\
\hline
\end{tabular}

The total recharge for 1980's land use of 216 $\mathrm{Mgal} / \mathrm{d}$ represents an increase of $32 \mathrm{Mgal} / \mathrm{d}$ over predevelopment recharge, all of it from irrigation-return flow. Recharge to the hydrologically important noncaprock area during the mid-1980's was $202 \mathrm{Mgal} / \mathrm{d}$ compared with $180 \mathrm{Mgal} / \mathrm{d}$ for predevelopment conditions, which is an increase of $22 \mathrm{Mgal} / \mathrm{d}$. Evapotranspiration increased a little more than 15 percent over predevelopment rates from 185 to about $213 \mathrm{Mgal} / \mathrm{d}$. Increases in recharge and evapotranspiration account for all estimated applied irrigation water (tables 17, 29).

\section{DISTRIBUTION OF MID-1980'S GROUND-WATER RECHARGE}

The distribution of ground-water recharge for mid1980 's land use for the island of Oahu is shown in figure 23 and given in table 30 . The influence of irrigated agriculture is noticeable in southern and north-central Oahu, where areas of significantly higher recharge are surrounded by areas of low recharge. In the natural land-use areas along the Koolau Range, the distribution of recharge generally follows the pattern of rainfall distribution (fig. 2).

The distribution of ground-water recharge and underflow for the southern and north-central areas of Oahu for mid-1980's land use is shown in figure 24. This distribution can be compared with the predevelopment distribution shown in figure 16. Recharge and underflow to the noncaprock areas of the Pearl Harbor groundwater area for mid-1980's land use is estimated to be $283 \mathrm{Mgal} / \mathrm{d}$, which is an increase of about $22 \mathrm{Mgal} / \mathrm{d}$ over predevelopment conditions and the result of irri- gation-return flow. Recharge and underflow to the noncaprock section of the Ewa ground-water area increased by $9 \mathrm{Mgal} / \mathrm{d}$ from predevelopment conditions. Similarly, recharge and underflow to the noncaprock areas of north-central Oahu increased by $22 \mathrm{Mgal} / \mathrm{d}$ from predevelopment conditions. Recharge to the caprock areas of southern and north-central Oahu was increased by irrigation-return flow to about $57 \mathrm{Mgal} / \mathrm{d}$, which is an increase of about $32 \mathrm{Mgal} / \mathrm{d}$ above predevelopment land-use conditions. Ground-water recharge to windward Oahu basins, the Waianae area, and southeastern Oahu was the same for mid-1980's and predevelopment land uses.

TABLE 30.-Distribution of ground-water recharge fo mid-1980's land use, island of Oahu

[In million gallons per day; - , no data or not applicable]

\begin{tabular}{|c|c|c|c|}
\hline $\begin{array}{c}\text { Area } \\
\text { (fig. 15) }\end{array}$ & $\begin{array}{l}\text { Caprock } \\
\text { area }\end{array}$ & $\begin{array}{l}\text { Noncaprock } \\
\text { area }\end{array}$ & Total \\
\hline 1 & - & 3.8 & 3.8 \\
\hline 2 & - & 193.7 & 193.7 \\
\hline 3 & 0.2 & 36.0 & 36.2 \\
\hline 4 & .8 & 32.0 & 32.8 \\
\hline 5 & 4.4 & 20.0 & 24.4 \\
\hline 6 & 9.1 & 6.9 & 16.0 \\
\hline 7 & .2 & 7.3 & 7.5 \\
\hline 8 & - & 1.3 & 1.3 \\
\hline 9 & - & 9.5 & 9.5 \\
\hline 10 & - & 7.7 & 7.7 \\
\hline 11 & - & 31.7 & 31.7 \\
\hline 12 & - & 11.5 & 11.5 \\
\hline 13 & - & 17.0 & 17.0 \\
\hline 14 & - & 64.1 & 64.1 \\
\hline 15 & - & 49.6 & 49.6 \\
\hline 16 & - & 31.3 & 31.3 \\
\hline 17 & .2 & 2.4 & 2.6 \\
\hline 18 & - & .5 & .5 \\
\hline 19 & - & .7 & .7 \\
\hline 20 & - & 11.2 & 11.2 \\
\hline 21 & - & 5.8 & 5.8 \\
\hline 22 & 9.0 & 14.8 & 23.8 \\
\hline 23 & 21.7 & 152.2 & 173.9 \\
\hline 24 & - & 21.4 & 21.4 \\
\hline 25 & 4.0 & 25.2 & 29.2 \\
\hline 26 & 1.0 & 16.1 & 17.1 \\
\hline 27 & 3.8 & 17.4 & 21.2 \\
\hline 28 & 2.0 & 10.2 & 12.2 \\
\hline 29 & .1 & 7.1 & 7.2 \\
\hline 30 & .4 & 8.9 & 9.3 \\
\hline 31 & - & 2.4 & 2.4 \\
\hline 32 & - & .5 & .5 \\
\hline 33 & - & .2 & .2 \\
\hline 34 & - & 1.6 & 1.6 \\
\hline 35 & - & .3 & .3 \\
\hline 36 & - & .0 & .0 \\
\hline Total....... & .. 56.9 & 822.3 & 879.2 \\
\hline
\end{tabular}




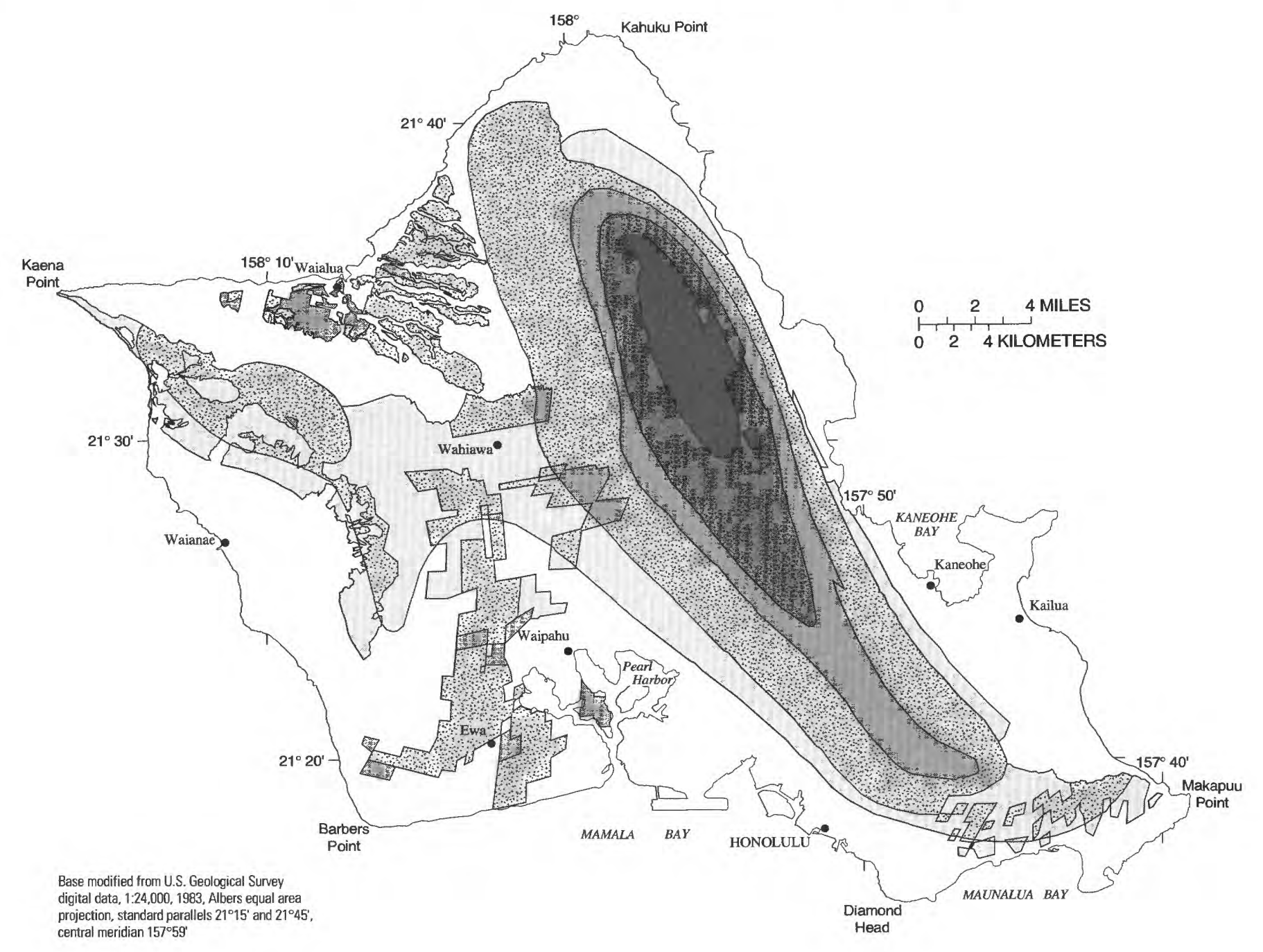

EXPLANATION

GROUND-WATER RECHARGE, IN INCHES PER YEAR

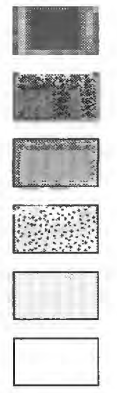

Greater than or equal to 150

Greater than or equal to 100 and less than 150

Greater than or equal to 50 and less than 100

Greater than or equal to 25 and less than 50

Greater than or equal to 10 and less than 25

Less than 10

FIGURE 23,-Distribution of ground-water recharge for mid-1980's land use, island of Oahu. 


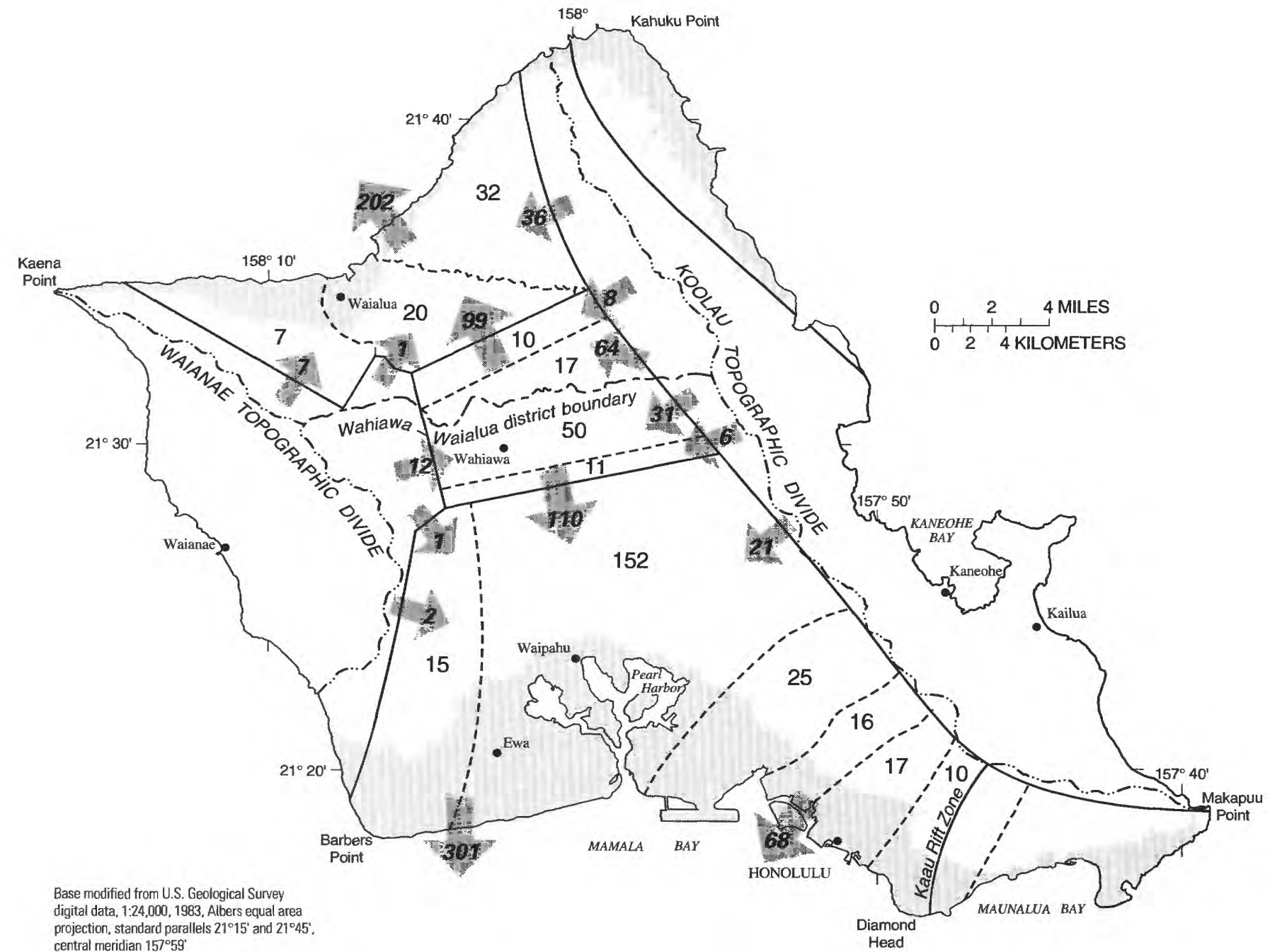

EXPLANATION

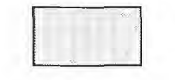

COASTAL PLAIN (caprock)

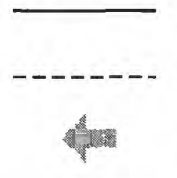

MAJOR GEOHYDROLOGIC BOUNDARY

SUBORDINATE GEOHYDROLOGIC BOUNDARY

DIRECTION OF UNDERFLOW

68 UNDERFLOW, IN MILLION GALLONS PER DAY

25 RECHARGE BY INFILTRATION OF PRECIPITATION

AND APPLIED IRRIGATION, IN MILLION

GALLONS PER DAY 
Estimated ground-water recharge for predevelopment and mid-1980's land uses for noncaprock areas and the total areas of the five major study areas of Oahu are summarized in table 31. Predevelopment and mid-1980's water budgets for southern and north-central Oahu are summarized in table 32 . These two areas are the only areas where the budgets were significantly affected by land-use changes. Table 33 summarizes the mid-1980's water budget for Oahu.

TABLE 31.-Estimated predevelopment and mid-1980's ground-water recharge to noncaprock areas and to the total areas, island of Oahu [In million gallons per day]

\begin{tabular}{|c|c|c|c|c|}
\hline \multirow[b]{2}{*}{$\begin{array}{l}\text { Study } \\
\text { area }\end{array}$} & \multicolumn{2}{|c|}{ Predevelopment } & \multicolumn{2}{|c|}{ Mid-1980's } \\
\hline & $\begin{array}{c}\text { Noncaprock } \\
\text { area }\end{array}$ & $\begin{array}{l}\text { Total } \\
\text { area }\end{array}$ & $\begin{array}{c}\text { Noncaprock } \\
\text { area }\end{array}$ & $\begin{array}{r}\text { Total } \\
\text { area }\end{array}$ \\
\hline Southern Oahu ${ }^{1}$............. & ..... 341 & 359 & 373 & 415 \\
\hline Southeastern Oahu ...... & ..... 19 & 19 & 19 & 19 \\
\hline Windward Oahu........... & ..... 198 & 198 & 198 & 198 \\
\hline North-central Oahu ${ }^{2} . .$. & ..... 180 & 184 & 202 & 216 \\
\hline Waianae area................. & ..... $\quad 32$ & 32 & 32 & 32 \\
\hline 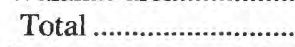 & ..... 770 & 792 & ${ }^{3} 824$ & ${ }^{3} 880$ \\
\hline
\end{tabular}

TABLE 32.-Predevelopment and mid-1980's water budgets for southern and north-central Oahu [In million gallons per day; -, not applicable]

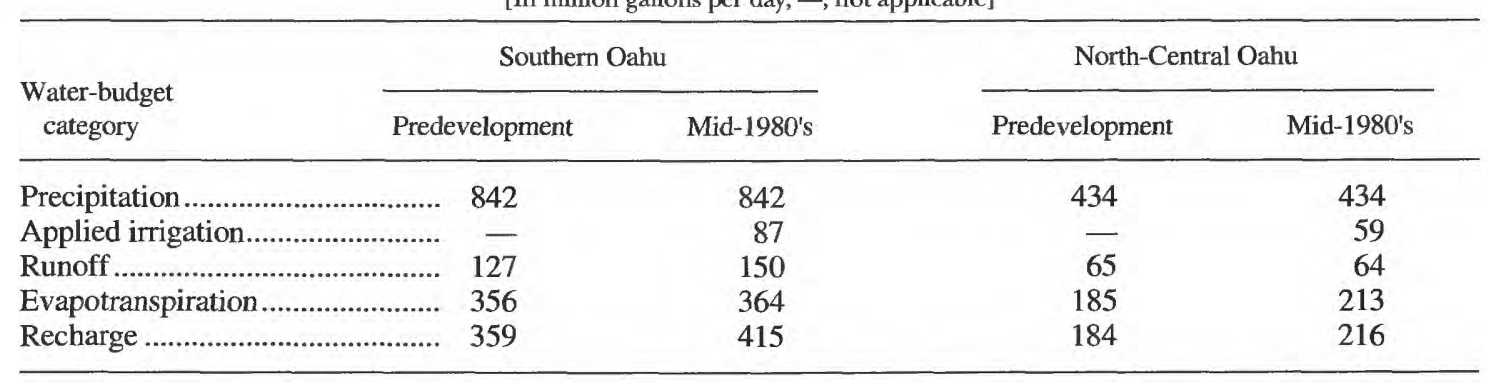

\begin{tabular}{|c|c|c|c|c|c|c|}
\hline $\begin{array}{l}\text { Water-budget } \\
\text { category }\end{array}$ & $\begin{array}{l}\text { Southern } \\
\text { Oahu }\end{array}$ & $\begin{array}{c}\text { Southeastern } \\
\text { Oahu }\end{array}$ & $\begin{array}{l}\text { Windward } \\
\text { Oahu }\end{array}$ & $\begin{array}{c}\text { North- } \\
\text { Central Oahu }\end{array}$ & Waianae & Oahu \\
\hline 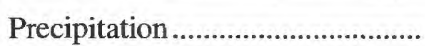 & 842 & 62 & 536 & 434 & 103 & 1,977 \\
\hline 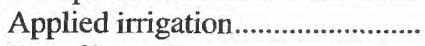 & 87 & - & - & 59 & - & 146 \\
\hline 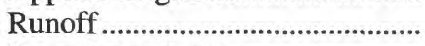 & 150 & 7 & 100 & 64 & 8 & 329 \\
\hline 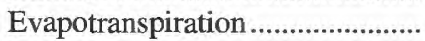 & 364 & 36 & 238 & 213 & 63 & 914 \\
\hline 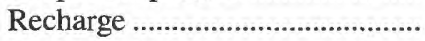 & 415 & 19 & 198 & 216 & 32 & 880 \\
\hline
\end{tabular}




\section{SUMMARY AND CONCLUSIONS}

Detailed water budgets were developed by previous investigators for southern and southeastern Oahu and for parts of windward Oahu. The methods used for these budgets have been simplified, incorporated into a geographic information system, and applied in a consistent manner to all areas of the island to provide an estimated water budget for Oahu for predevelopment and mid-1980's land uses. Predevelopment recharge to the ground-water system of Oahu was estimated to be $792 \mathrm{Mgal} / \mathrm{d}$, including recharge to the noncaprock part of the island estimated to be $770 \mathrm{Mgal} / \mathrm{d}$.

The effects of changes in land use on ground-water recharge were evaluated for southern and north-central Oahu, where significant changes have been caused by urbanization and agriculture. Urbanization in southern Oahu has led to an increase in estimated runoff of about 18 percent, or $23 \mathrm{Mgal} / \mathrm{d}$. The rate of predevelopment recharge to areas of southern Oahu having nonagricultural land uses during the 1980's would have been about 328 $\mathrm{Mgal} / \mathrm{d}$; recharge to these areas during the mid-1980's was estimated to be about $327 \mathrm{Mgal} / \mathrm{d}$. Irrigated agriculture has had a much greater effect on recharge, and has led to an estimated increase of about $56 \mathrm{Mgal} / \mathrm{d}$ for the entire area over predevelopment recharge. However, the estimated recharge from irrigated sugarcane determined by earlier studies may be overestimated by a factor of two; more detailed investigations are needed to resolve this issue.

A comparison of the predevelopment and the mid1980's water budgets for Oahu indicates an increase in runoff of $22 \mathrm{Mgal} / \mathrm{d}$ as a result of increased urbanization in the 1980's. The estimated increase in evapotranspiration of $36 \mathrm{Mgal} / \mathrm{d}$ in the 1980's is a result of irrigated agriculture in the southern and north-central areas. Islandwide, a substantial increase in estimated recharge of $88 \mathrm{Mgal} / \mathrm{d}$ in the 1980's was similarly the result of irrigated agriculture. The mid-1980's island ground-water recharge was estimated to be 880 $\mathrm{Mgal} / \mathrm{d}$, of which $822 \mathrm{Mgal} / \mathrm{d}$ recharged the noncaprock area.

\section{REFERENCES CITED}

Campbell, R.B., Chang, J.H., and Cox, D.C., 1959, Evapotranspiration of sugarcane as measured by field lysimeters in relation to climate: International Society Sugarcane Technologists, 10th International Congress, Proceedings, p. 637-649.

Dale, R.H., 1967, Land use and its effects on the basal water supply, Pearl Harbor area, Oahu, Hawaii, 1931-65: U.S. Geological Survey Hydrologic Investigations Atlas HA-267, 2 sheets, scale 1:62,500.
1978, A ground-water inventory of the Waialua basal-water body, Island of Oahu, Hawaii: U.S. Geological Survey Open-File Report OF 78-24, 71 p.

Dale, R.H., and Takasaki, K.J., 1976, Probable effects of increasing pumpage from the Schofield ground-water body, Island of Oahu, Hawaii: U.S. Geological Survey Water-Resources Investigations Report 76-47, $45 \mathrm{p}$.

Ekern, P.C., and Chang, J.H., 1985, Pan evaporation in Hawaii, 18941970: State of Hawaii, Department of Land and Natural Resources Report R74, 171 p.

Eyre, P.R., Ewart, C.J., and Shade, P.J., 1986, Hydrology of the leeward aquifers, southeast Oahu, Hawaii: U.S. Geological Survey Water-Resources Investigations Report 85-4270, 75 p.

Eyre, P.R., and Nichols, W.D., in press, Regional analysis of the southern Oahu ground-water flow system, Hawaii: U.S. Geological Survey Water-Resources Investigations Report 954256.

Foote, D.E., Hill, E.L., Nakamura, Sakuichi, and Stephens, Floyd, 1972, Soil survey of islands of Kauai, Oahu, Maui, Molokai, and Lanai, State of Hawaii: U.S. Department of Agriculture, Soil Conservation Service, $232 \mathrm{p}$.

Giambelluca, T.W., 1983, Water balance of the Pearl Harbor-Honolulu basin, Hawaii, 1946-1975: University of Hawaii, Water Resources Research Center Technical Report 151, 151 p. 1986, Land-use effects on the water balance of a tropical island: National Geographic Research, v. 2, no. 2, p. 125-151.

Giambelluca, T.W., Nullet, M.A., and Schroeder, T.A., 1986, Rainfall atlas of Hawaii: State of Hawaii, Department of Land and Natural Resources Report R76, 267 p.

Mink, J.F., 1980, State of the groundwater resources of southern Oahu: City and County of Honolulu, Board of Water Supply, $80 \mathrm{p}$.

Rosenau, J.C., Lubke, E.R., and Nakahara, R.H., 1971, Water resources of north-central Oahu, Hawaii: U.S. Geological Survey Water-Supply Paper 1899-D, 40 p.

Stearns, H.T., 1939, Geologic map and guide of the Island of Oahu, Hawaii: Hawaii Division of Hydrography Bulletin 2, 75 p., map scale 1:62,500.

Stearns, H.T. and Vaksvik, K.N., 1935, Geology and ground-water resources of the island of Oahu, Hawaii: Hawaii Division of Hydrography Bulletin 1, $479 \mathrm{p}$.

Takasaki, K.J., 1971, Ground water in the Waianae District, Oahu, Hawaii: U.S. Geological Survey Hydrologic Investigations Atlas HA-358, 2 sheets, scale 1:62,500.

1978 , Summary appraisals of the Nation's ground-water resources; Hawaii region: U.S. Geological Survey Professional Paper 813-M, 29 p.

Takasaki, K.J., Hirashima, G.T., and Lubke, E.R., 1969, Water resources of windward Oahu, Hawaii: U.S. Geological Survey Water-Supply Paper 1894, $119 \mathrm{p}$.

Takasaki, K.J., and Mink, J.F., 1985, Evaluation of major dikeimpounded ground-water reservoirs, island of Oahu with a section on Flowing hydraulics in dike tunnels in Hawaii, by J.F. Mink: U.S. Geological Survey Water-Supply Paper 2217, 77 p.

Takasaki, K.J., and Valenciano, Santos, 1969, Water in the Kahuku area, Oahu, Hawaii: U.S. Geological Survey Water-Supply Paper 1874,59 p.

U.S. Geological Survey, 1970, 1968 Water resources data for Hawaii and other Pacific areas: U.S. Geological Survey, 296 p.

1971, 1969 Water resources data for Hawaii and other Pacific areas: U.S. Geological Survey, 289 p.

1972, 1970 Water resources data for Hawaii and other Pacific areas: U.S. Geological Survey, 299 p.

Visher, F.N., and Mink, J.F., 1964, Ground-water resources in southern Oahu, Hawaii: U.S. Geological Survey Water-Supply Paper 1778, $133 \mathrm{p}$. 
Wentworth, C.K., 1951, Geology and ground-water resources of the Honolulu-Pearl Harbor area, Oahu, Hawaii: City and County of Honolulu, Board of Water Supply, 111 p.

Zones, C.P., 1963, Preliminary report on the ground-water resources of the Waianae area, Oahu, Hawaii: State of Hawaii, Department of Land and Natural Resources Circular C16, 12 p. 


\section{SELECTED SERIES OF U.S. GEOLOGICAL SURVEY PUBLICATIONS}

\section{Periodical}

Preliminary Determination of Epicenters (issued monthly)

\section{Technical Books and Reports}

Professional Papers are mainly comprehensive scientific reports of wide and lasting interest and importance to professional scientists and engineers. Included are reports on the results of resource studies and of topographic, hydrologic, and geologic investigations. They also include collections of related papers addressing different aspects of a single scientific type.

Bulletins contain significant data and interpretations that are of lasting scientific interest but are generally more limited in scope or geographic coverage than Professional Papers. They include the results of resource studies and of geologic and topographic investigations, as well as collections of short papers related to a specific topic.

Water-Supply Papers are comprehensive reports that present significant interpretive results of hydrologic investigations of wide interest to professional geologists, hydrologists, and engineers. The series covers investigations in all phases of hydrology, including hydrogeology, availability of water, quality of water, and use of water.

Circulars present administrative information or important scientific information of wide popular interest in a format designed for distribution at no cost to the public. Information is usually of short-term interest.

Water-Resources Investigations Reports are papers of an interpretive nature made available to the public outside the formal USGS publications series. Copies are reproduced on request, unlike formal USGS publications, and they also are available for public inspection at depositories indicted in USGS catalogs.

Open-File Reports include unpublished manuscript reports, maps, and other material that are made available for public consultation at depositories. They are a nonpermanent form of publication that may be cited in other publications as sources of information.

\section{Maps}

Geologic Quadrangle Maps are multicolor geologic maps on topographic bases in 7.5- or 15-minute quadrangle formats (scales mainly 1:24,000 or 1:62,500) showing bedrock, surficial, or engineering geology. Maps generally include brief texts; some maps include structure and columnar sections only.

Geophysical Investigations Maps are on topographic or planimetric bases at various scales; they show results of surveys using geophysical techniques, such as gravity, magnetic, seismic, or radioactivity, which reflect subsurface structures that are of economic or geologic significance. Many maps include correlations with the geology.

Miscellaneous Investigations Series Maps are on planimetric or topographic bases of regular and irregular areas at various scales; they present a wide variety of format and subject matter. The series also includes 7.5-minute quadrangle photogeologic maps on planimetric bases that show geology as interpreted from aerial photographs. Series also includes maps of Mars and the Moon.
Coal Investigations Maps are geologic maps on topographic or planimetric bases at various scales showing bedrock or surficial geology, stratigraphy, and structural relations in certain coal-resource areas.

Oil and Gas Investigations Charts show stratigraphic information for certain oils and gas fields and other areas having petroleum potential.

Miscellaneous Field Studies Maps are multicolor or blackand-white maps on topographic or planimetric bases for quadrangle or irregular areas at various scales. Pre-1971 maps show bedrock geology in relation te specific mining or mineral-deposit problems: post-1971 maips are primarily black-and-white maps on various subjects such as environmental studies or wilderness mineral investigations.

Hydrologic Investigations Atlases are multicolored or blackand-white maps on topographic or planimetric bases presenting a wide range of geohydrologic data of both regular and irregular areas; principal scale is 1:24,000, and regional studies are at $1: 250,000$ scale or smaller.

\section{Catalogs}

Permanent catalogs, as well as some others, giving comprehensive listings of U.S. Geological Survey publications are available under the conditions indicated below from the U.S. Geological Survey, Information Services, Box 25286. Federal Center, Denver, CO) 80225. (See latest Price and Availability List.)

"Publications of the Geological Survey, 1879-1961" may be purchased by mail and over the counter in paperback book form and as a set of microfiche.

"Publications of the Geological Survey, 1962-1970" may be purchased by mail and over the counter in paperback book form and as a set of microfiche.

"Publications of the U.S. Geological Survey, 1979-1981" may be purchased by mail and over the counter in paperback book form (two volumes, publications listing and index) and as a set of microfiche.

Supplements for 1982, 1983, 1984, 1985, 1986, and for subsequent years since the last permanent catalog may be purchased by mail and over the counter in paperback book form.

State catalogs, "List of U.S. Geological Survey Geologic and Water-Supply Reports and Maps for (State)" may be purchased by mail and over the counter in paperback booklet form only.

"Price and Availability List of U.S. Geological Survey Publications," issued annually, is available free of charge in paperback booklet form only.

Selected copies of a monthly catalog, "New Publications of the U.S. Geological Survey," are available free of charge by mail or may be obtained over the counter in paperback booklet form only. Those wishing a free subscription to the monthly catalog "New Publications of the U.S. Geological Survey" should write to the U.S. Geological Survey, 582 National Center, Reston, VA 20192.

Note.-Prices of Government publications listed in older catalogs, announcements, and publications may be incorrect. Therefore, the prices charged may differ from the prices in catalogs, announcements, and publications. 


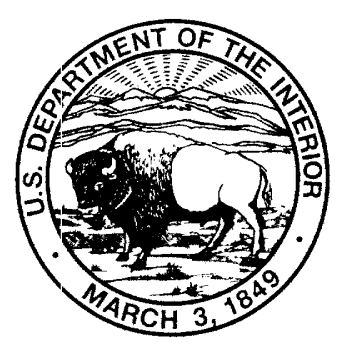

ISBN $0-607-86103-7$

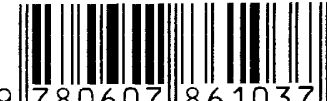

